NBER WORKING PAPER SERIES

\title{
WAGE MOBILITY IN THE \\ UNITED STATES
}

\author{
Moshe Buchinsky \\ Jennifer Hunt
}

Working Paper 5455

\section{NATIONAL BUREAU OF ECONOMIC RESEARCH 1050 Massachusetts Avenue \\ Cambridge, MA 02138 \\ February 1996}

We thank Ron Goettler for expert research assistance, Rachel Friedberg, Guido Imbens, and Joel Waldfogel for helpful discussions, and seminar participants at the Hebrew University of Jerusalem, INSEE-CREST, McMaster University, NBER, University of British Columbia, and University of Washington for useful comments. Financial support to the first author from the NSF under grant SBR9320386 is acknowledged. This paper is part of NBER's research program in Labor Studies. Any opinions expressed are those of the authors and not those of the National Bureau of Economic Research.

(C) 1996 by Moshe Buchinsky and Jennifer Hunt. All rights reserved. Short sections of text, not to exceed two paragraphs, may be quoted without explicit permission provided that full credit, including $\odot$ notice, is given to the source. 


\title{
WAGE MOBILITY IN THE \\ UNITED STATES
}

\begin{abstract}
This paper examines the mobility of individuals through the wage and earnings distributions. This is of extreme importance since mobility has a direct implication for the way one views the vast changes in wage and earnings inequality in the United States over the last few decades. The measures of wage and earnings mobility analyzed are based on data for individuals surveyed in the National Longitudinal Survey for Youth from 1979 to 1991.

We introduce summary measures of mobility computed over varying time horizons in order to examine how the effect on measured inequality as the time horizon is increased. The results suggest that mobility is predominantly within group mobility and increases most rapidly when the time horizon is extended up to four years, reducing wage inequality by $12-26 \%$. We proceed therefore with more detailed examination of short-term (year-to-year) within group mobility, by estimating non-parametrically transition probabilities among quintiles of the distribution. We find that the staying probabilities, by quintiles, were higher at the higher quintiles throughout the period for both wages and earnings, and that mobility is declining over time. Hence, this paper suggests that while the level of wage inequality in the United States is somewhat lower once mobility is taken into account, the sharp increase in inequality during the 1980 's is worse than it appears, due to falling mobility over time.
\end{abstract}

Moshe Buchinsky

Cowles Foundation for Research in Economics

Department of Economics

Yale University

PO Box 280264, Yale Station

New Haven, CT 06520-8264

and NBER
Jennifer Hunt

Department of Economics

Yale University

PO Box 208264, Yale Station

New Haven, CT 06520-8264 


\section{Introduction}

Numerous papers have documented the level of wage inequality in the United States and its rise during the 1980s, both of which are high by international standards (see Levy and Murnane (1992) for a summary). For example, the 90-10 log wage differential rose by almost $30 \%$ from the late 1960s to 1987 (Katz and Murphy (1992)), and in 1989 was about 28\% higher than in Britain (Katz, Loveman and Blanchflower (1993)). However, the degree of concern about a given level of inequality must be related to the extent of individuals' mobility through the distribution over time. If there is a lot of churning in the distribution as individuals move relative to one another, lifetime wages will be much more equally distributed than the wages from any single year. Hence high mobility is likely to reduce our concern about high inequality at a given point in time, although the implied high uncertainty about future wage streams must be weighed against the benefit of equality. Similarly, rising point-in-time inequality could be offset by rising mobility. This paper evaluates how the consideration of individuals' mobility through the wage distribution affects our view of wage inequality patterns in the United States.

We present measures of mobility through the wage distribution of individuals surveyed in the NLSY from 1979 to 1991 . In the first part we use a summary measure of mobility to establish how mobility reduces inequality as the time horizon is increased. Mindful of the very different patterns in wage inequality within groups of individuals with the same observable characteristics, and between these groups, we decompose the measure of mobility into within and between group components. Within group inequality is the larger part of total inequality, and has been rising steadily since the late 1960s, while returns to observable characteristics (which underlie between group inequality) have fluctuated in recent decades (the return to education, for example, fell in the 1970s and rose in the 1980s) (Katz and Murphy (1992)). 
Our assessment of the relative significance of these inequality components is affected by the corresponding mobility measures.

This initial analysis suggests that mobility is predominantly within-group mobility and increases most rapidly when the time horizon is extended up to four years, reducing wage inequality by $12-26 \%$. Therefore, the second part of the paper is devoted to the examination of short-term (in particular, year-to-year) within-group mobility, by estimating non-parametrically the transition probabilities from one quintile to another. We find that the probability of staying in a quintile was higher at the higher quintiles throughout the period for both wages and annual earnings, and that mobility is declining over time. Hence, our paper suggests that while the level of inequality in the United States wage distribution is somewhat lower once mobility is taken into account, the increase in inequality in the $1980 \mathrm{~s}$ is worse than it appears, due to falling mobility over time.

A large number of papers seek to measure wage or annual earnings mobility for different countries and time periods using a wide variety of samples and mobility measures (many of these are summarized in Atkinson, Bourguignon and Morrisson (1992)). In addition to updating previous work, our paper has the novelty of taking zero wages (non-employment) into consideration. We also combine features found dispersed among previous papers. We include all individuals, both male and female, and examine both hourly wages and annual earnings. Furthermore, we decompose mobility into between and within group components based on regression analysis rather than group means. We examine explicitly who moves where in the distribution, and report standard errors throughout.

The issue of the effect of time horizon on wage mobility has been examined previously by Shorrocks (1981). He finds that mobility causes a fall in inequality of up to $27 \%$ after four years for male household heads from the PSID. The distinction between wage mobility between 
and within groups has received little attention, however (Maasoumi and Zandvakili (1990) decompose income mobility into between and within gender groups).

Several papers have focused on within group movement of wages by modelling the dynamic error structure of wage regressions using male household heads in the PSID (Lillard and Willis (1978), Lillard and Weiss (1979), MaCurdy (1982), Abowd and Card (1989), Moffitt and Gottschalk (1993)). Moffitt and Gottschalk (1993) work with the residuals from wage regressions to calculate two measures of mobility: the ratio of variance of transitory earnings to the variance of permanent earnings, and the inverse of the "immobility ratio" (obtained by summing off-diagonal elements in a transition matrix). They find evidence that mobility for time horizons of up to five years fell in the 1970 s and 1980s and the variance of both transitory and permanent earnings rose.

The remainder of the paper is organized as follows. Section 2 describes the data and addresses various problems associated with data and the sample. Section 3 provides the results for the analysis of long-term inequality and mobility measures. In Section 4 we present the results of the nonparametric estimates of the transition probabilities and provide additional analysis of alternative measure of mobility which are based on the estimated transition probabilities among quintiles of the distribution. Section 5 provides a summary and concluding remarks.

\section{Data and Sample}

The National Longitudinal Survey of Youth (NLSY) was chosen over the more usual Panel Study of Income Dynamics (PSID) data set due to the difficulty of obtaining the relevant information for individuals other than household heads (who are male unless only a female adult is present) in the PSID. We include individuals of both sexes and all races. The drawback of the NLSY is 
clearly that the respondents are young (14-24 in 1979) - hence all results obtained have a caveat attached that they may apply only to young people. This caveat was considered preferable to the "male household head" caveat, for example, since youth are a well-defined group whose welfare is of interest to us separately from that of other age groups. One further drawback is that as the NLSY is a cohort study, the average age of the respondents is increasing, and separating age and time effects is more difficult than in the PSID.

In this study we analyze the distribution of hourly wages in the survey week, and annual earnings in the previous year. Both are deflated by the implicit price deflator of personal consumption expenditures for gross national products (reported in the Economic Report of the President, 1995).

The results reported here are based on data of individuals who were not enrolled in school at the time of the survey (for wage analysis) or at any point in the year (for earnings analysis). Similar exclusions apply to military personnel and the self-employed. The schooling restriction is intended to eliminate individuals working at part-time jobs before the end of their education, since the wages on these jobs may not accurately reflect individuals' attributes and ability. Valid wage observations are those which occur after the last increment to the individual's education as observed in the data set. Because so many respondents were in school in the early years, the first part of the paper uses survey years 1981-1991, while the second uses 1980-1991. Table I reports the number of observations for which data were available, for both wages and earnings. As the table indicates, there are between 3,300 and 8,000 observations for each year that were actually used in calculating the various measures and transition probabilities. ${ }^{4}$

Outlier observations are naturally an important issue. Wages greater than five times the maximum or less than one fifth of the minimum of a respondent's wages in other years, as

\footnotetext{
4 In 1991 the sample size drops considerably as the white poverty subsample was dropped by the survey.
} 
well as wages below $\$ 1$ in 1979 dollars, were dropped from the analysis carried out in the first part of the paper. Outliers in earnings were eliminated in the same way on the basis of the annual wage, as calculated by the ratio of annual earnings to annual hours. We do use these observations in the second part of the paper, where we estimate transition probabilities between quintiles and we only concerned with the order of the observations.

The current mobility literature does not address the problem of individuals who have some observations of zero earnings in the period of interest. ${ }^{5}$ If data are available for a ten year period, it is common to conduct analyses solely on those with valid earnings in all ten years. Such results are presented in Section 3 below, but the resulting sample size is tiny, and probably unrepresentative (this sample shall be referred to as the consistent sample).

We also examine results for the maximum possible sample for the period or sub-period in question (this sample shall be referred to as the maximum sample). Thus, mobility measured over two years will in general be based on a larger sample than mobility measured over four years, and two-year mobility (in either Section 3 or Section 4) measured for different pairs of years will be based on different samples. Strictly speaking this renders the two numbers incomparable: if mobility appears to rise with the time horizon, it could be due to a genuine increase in mobility, or to the inclusion of different individuals. The main conclusions drawn from the results do not, however, appear to be sensitive to this aspect of the construction of the sample (as in the case of the treatment of outliers, the level of inequality and mobility are affected, but not the patterns of importance). Finally, some measures are presented including zeros as observations.

Among the variables we use are actual experience, constructed with the help of a variable

\footnotetext{
${ }^{5}$ This is not an issue if income is the variable of interest; the problem is partially circumvented in the earnings literature by confining attention to men.
} 
providing experience in 1976-78. We augment the reported experience in this variable by the weeks of experience reported in each of the years thereafter.

\section{Mobility and Inequality Over Varying Time Horizons}

\subsection{Measurement of Inequality and Mobility}

\section{Inequality}

The measure of mobility used in this section is based upon particular measures of inequality, which shall be described first. An inequality index decomposable into within and between group components is required, and the set of such indices is the family of generalized entropy measures (and transformations of them such as the Atkinson index and coefficient of variation: see Shorrocks (1984)). If the population of interest is divided into groups, total inequality may be expressed as the sum of inequality between the groups and inequality within the groups. In the usual decomposition, inequality within a group is simply found by applying the inequality index to the wages of that group (if the wage is the outcome of interest), and the within component of total inequality is a weighted sum of the inequalities within each group. Between inequality is found by applying the inequality index to the mean wages of the groups. Ignoring for the moment two special cases, total inequality in the generalized entropy family may be written:

$$
I_{c}=\frac{1}{n} \frac{1}{c(c-1)} \sum_{i=1}^{n}\left[\left(\frac{w_{i}}{\bar{w}}\right)^{c}-1\right], \quad c \neq 0,1,
$$

where $w_{i}$ is the wage of an individual, $\bar{w}$ is the population mean, $n$ is the population size and $c$ is a parameter indicating which end of the distribution the index is more sensitive to (higher $c$ means the index is more sensitive to inequality in the upper part of the distribution) ${ }^{6}$ If there

\footnotetext{
${ }^{6}$ For the value $c=2$ this index is equal to one half of the square of the coefficient of variation: $I_{2}=C V^{2} / 2$.
} 
are $k$ groups each with a share in the population $v_{k}$ and inequality $I_{c}^{k}$, this may be rewritten as the sum of within and between components:

$$
I_{c}=I_{c}^{W}+I_{c}^{B}=\sum_{k} v_{k}\left(\frac{\bar{w}_{k}}{\bar{w}}\right)^{c} I_{c}^{k}+\frac{1}{c(c-1)} \sum_{k} v_{k}\left[\left(\frac{\bar{w}_{k}}{\bar{w}}\right)^{c}-1\right],
$$

where $\bar{w}_{k}$ is the group mean.

Following Morduch and Sicular (1994), in this paper the between group component, rather than being based upon the group sample mean wages, is based upon the group wages as predicted using coefficients from a wage regression for the whole population. Hence, in this formulation a group consists of all individuals with the same observable characteristics used in the regression. This results in a more efficient estimator of the group mean. Before writing the expression for the between component, it is useful to write the expression for total inequality slightly differently, taking the need to consider sample weights $z_{i}$ into account (assume the sample weights are normalized to sum to 1 ):

$$
I_{c}=\frac{1}{c(c-1)} \sum_{i=1}^{n} z_{i}\left[\left(\frac{w_{i}}{\sum_{j=1}^{n} z_{j} w_{j}}\right)^{c}-1\right], \quad c \neq 0,1
$$

The between component of inequality has the same form, but with the actual wages of the individuals replaced by their predicted wages $\hat{w}_{i}$ :

$$
I_{c}^{B}=\frac{1}{c(c-1)} \sum_{i=1}^{n} z_{i}\left[\left(\frac{\hat{w}_{i}}{\sum_{j=1}^{n} z_{j} \hat{w}_{j}}\right)^{c}-1\right], \quad c \neq 0,1
$$

The use of sample weights allows us to sum over individuals rather than groups. The within component may be calculated substituting the predicted wage for the actual wage where appropriate in the expression for $I_{c}^{w}$ (written as a function of sample weights), and some rearrangement shows that, as expected, this equals the difference between total and between inequality.

For the two special cases of $c=0$ and $c=1$ (known as the Theil- $L$ and Theil inequality 
indices respectively) the formulae for total inequality are:

$$
I_{0}=\sum_{i=1}^{n} z_{i} \log \left(\frac{\sum_{j=1}^{n} z_{j} w_{j}}{w_{i}}\right)
$$

and

$$
I_{1}=\sum_{i=1}^{n} z_{i} \frac{w_{i}}{\sum_{j=1}^{n} z_{j} w_{j}} \log \left(\frac{w_{i}}{\sum_{j=1}^{n} z_{j} w_{j}}\right)
$$

The expressions for between and within components are obtained using the same logic as for the general case.

A weighted least squares regression with $\log$-linear specification is used to predict wages, so predicted wages are approximated as $\hat{w}_{i}=\exp \left\{X_{i} \hat{\beta}\right\} \exp \left\{\frac{\hat{\sigma}_{j}^{2}}{2}\right\}$ for individual $i$ in group $j{ }^{7}$ The covariates used are age in 1979, maximum education obtained, sex and race, which are all time-invariant. Changes in between inequality are hence due to changes in the returns to these attributes.

\section{Mobility}

The measurement of mobility has not received as much theoretical attention as the measurement of inequality, and there is no consensus on the best measures. The measure used in this first section exploits the measures of inequality described above. If the wage used in the inequality measure is an average of several years' wages instead of being the wage from a single year, it is known that the measured inequality falls, reflecting mobility of individuals through the wage distribution. The relation between this lower inequality and the inequality in the individual years, captures mobility which can be defined:

$$
M=1-\frac{I\left(\frac{1}{T} \sum_{t} w_{t}\right)}{\left(\sum_{t} \eta_{t} I\left(w_{t}\right)\right)},
$$

\footnotetext{
${ }^{7}$ Longitudinal sample weights are approximated as the average of the relevant cross-section weights provided by the NLSY.
} 
where $w_{t}$ represents the vector of individual wages in year $t$, and $\eta_{t}$ indicates the share of wages earned in year $t$ in total wages earned in the $T$ year period. This index thus measures the percent by which inequality measured over a $T$ year horizon is lower than the average of the individual years in the horizon. We can rewrite this as a decomposition of mobility into between and within mobility, weighted by the share of between and within inequality in total cross-section inequality $S_{T}^{B}$ and $S_{T}^{W}$ :

$$
\begin{aligned}
M & =\left[1-\frac{I^{B}\left(\frac{1}{T} \sum_{t} w_{t}\right)}{\sum_{t} \eta_{t} I^{B}\left(w_{t}\right)}\right] \frac{\sum_{t} \eta_{t} I^{B}\left(w_{t}\right)}{\sum_{t} \eta_{t} I\left(w_{t}\right)}+\left[1-\frac{I^{W}\left(\frac{1}{T} \sum_{t} w_{t}\right)}{\sum_{t} \eta_{t} I^{W}\left(w_{t}\right)}\right] \frac{\sum_{t} \eta_{t} I^{W}\left(w_{t}\right)}{\sum_{t} \eta_{t} I\left(w_{t}\right)} \\
& =M^{B} S_{T}^{B}+M^{W} S_{T}^{W}
\end{aligned}
$$

\subsection{Results}

\section{Wages}

The first set of measures of inequality and mobility for selected time periods is presented in Table II (notice that all coefficients and standard errors are multiplied by 100 ) ${ }^{8}$ The inequality index used is the Theil- $L(c=0)$ and the maximum sample is used. The first panel presents measures of inequality based on single years of data (there is of course no meaningful mobility with only one time period), and the principal remark is that between inequality represents only $20-29 \%$ of total inequality. There is a trend over time (or age) towards increased inequality in both components.

The next panel presents inequality and mobility measures for selected pairs of years. Notice first of all that, as expected, total inequality measured over two years falls (statistically) significantly compared to the one-year measure. Most of this reduction is due to a reduction in the within component, which means that between inequality becomes a larger proportion of

\footnotetext{
${ }^{8}$ The standard errors are calculated using the delta method. They do not take into account clustering and stratification of the sample. See Howes and Lanjouw (1995).
} 
total inequality (24-30\%).

The reduction of inequality is more properly measured by the mobility index, which indicates that inequality measured over a two year horizon is between $7.2 \%$ (for the latest years) and $14.8 \%$ (for the earliest years) lower than the average inequality in the two years. Unlike the total inequality measure, total mobility has not been decomposed additively into between and within components - rather between and within mobility measures, unweighted by the shares of between and within inequality, are presented $\left(M^{B}\right.$ and $M^{W}$ in the notation above). The small reduction in between inequality when the horizon is expanded from one to two years is reflected in the low and statistically insignificant mobility measure for between. Within group mobility is correspondingly somewhat higher than total mobility (that is, an individual is more mobile within his or her group than within the distribution as a whole). There is a trend toward higher inequality and reduced mobility over time or age.

The third panel reproduces the measures for a four-year horizon. Mobility rises significantly, driven by a rise in within group mobility. This implies a reduction in inequality of $13.5-23.5 \%$ compared to the inequality average across each year, driven by a fall in within group inequality. The share of between inequality rises slightly to $25-31 \%$ of total inequality, but between mobility remains insignificant. The trend towards higher inequality and reduced mobility over time (or age) remains. As the time horizon is extended further in subsequent panels, the reduction in inequality and increase in mobility slows for horizons measured beginning in earlier years of the sample (we will return to this point).

These results paint the following picture of inequality and mobility. For short time horizons (especially one year), between inequality is a small fraction of inequality. As time horizons lengthen, however, between inequality falls slightly, and somewhat increases its share of inequality, although never exceeding $32 \%$ of the total. As the horizon is expanded from one to 
four years, total inequality falls by $13-23 \%$, and within inequality by $18-29 \%$, suggesting that although an important part of inequality is due to transitory shocks to wages, the larger part is due to long-term causes. Over a ten year horizon, total inequality falls by $27 \%$ and within inequality by $32 \%$. If all characteristics of individuals were observed, the within component would contain only shocks orthogonal to individual characteristics, and should go to zero over long enough horizons. One interpretation of the results is that the core of within inequality that remains over longer horizons represents inequality due to unobservable characteristics of individuals (which include quality of education, for example, as well as "ability").

These inequality results may be expressed more simply by saying that measured total mobility rises as the time horizon is expanded to four years, but rises more slowly thereafter according to some measures, and that most of the level of mobility and the increase in mobility are due to within group mobility. Over time or age, for a given time horizon, both components of inequality rise and mobility (particularly within) falls. The measures of mobility are little affected by measurement error - this is discussed further below.

The techniques used in this first part of the paper do not allow time and age effects to be separated. It is known that mobility is higher among the young, for example, thus falling mobility over time in the NLSY is likely to reflect aging of the sample and time effects (see Atkinson, Bourguignon and Morrisson (1992)). It is a simple matter to calculate the inequality and mobility if the wages are adjusted to eliminate differences due to age. However, it is well known that the return to education, for example, increases with age, so such a simple age adjustment would ignore the fact that inequality is rising with age partly due to the increasing return to education. It is, however, impossible to distinguish between age and time effects on the return to education in the NLSY. ${ }^{9}$

\footnotetext{
It is never possible to identify time, age, and cohort effects; we have simplified the discussion by implicitly
} 
The results examined so far are based upon only one value of inequality aversion (c) and on an unorthodox sample. The sensitivity of the results to the choice of sample is addressed in Table III, which for the same inequality index $(c=0)$ recalculates the measures based upon the sample of individuals who have valid non-zero wage observations in all years 1981 through 1991 . The first remark is that, not surprisingly, this consistent sample does look different from the larger sample: measured inequality and mobility are lower for the consistent sample for shorter time horizons where the samples differ most. Between inequality in the consistent sample is a slightly smaller proportion of the total (20-23\%). Mobility between groups appears higher in this consistent sample, but is still insignificantly different from zero.

Most of the results from Table II, applies to Table III as well, although the standard errors are larger. Inequality falls and mobility rises when the time horizon lengthens, especially up to the four-year horizon, driven by a reduction in within inequality and a rise in within mobility. Inequality falls to between $12.5 \%$ and $22.5 \%$ when the horizon is expanded from one to four years. Inequality rises and mobility falls over time or age (standard errors on inequality are large, though), although the between component rises less over time compared to the larger sample case.

Some of the total mobility results from Tables II and III are graphed in Figure 1 with points labelled " $c=0$ ". The two upper graphs are for the consistent sample, the lower two for the maximum sample. The left two graphs depict horizons beginning in 1981 (1981-2, 19814 etc), while the right two depict horizons ending in 1991 (1990-91, 1988-91 etc). The curves labelled " $c=2$ " indicate that total mobility is not very sensitive, in either sample, to increasing sensitivity to inequality at the top of the distribution. Table IV gives the full results for the maximum sample using $c=2$ (half the coefficient of variation squared), and shows that the assuming that cohort effects are negligible. 
differences between $c=0$ and $c=2$ are not always significant. Between inequality and mobility have levels similar to the $c=0$ case, and hence have a smaller share of total inequality and mobility (and between mobility remains insignificant). Inequality falls by $19.3-26.0 \%$ as the time horizon is expanded from one to four years.

The measures of inequality and mobility were calculated for a wide range of other values of $c$. As $c$ becomes large in absolute magnitude, and more weight is put on one of the tails, inequality rises. Within inequality rises more rapidly, so that between becomes a trivial fraction of total inequality. Focusing on a tail also causes measured mobility to rise until it approaches 1. Figure 2 shows total mobility for a range of c's, and also for a range of time horizons (the initial year being 1981 in all cases, as an illustration), using the maximum sample. Mobility orderings by time horizon are generally, but not perfectly, preserved across c.

The shapes of the curves are driven by changes in the within group inequality. Between mobility is relatively insensitive to $c$ over a wide range of $c$ (these results are not shown). Other results not presented show that the reduction in mobility over time or age holds for a wide but not full range of $c$ 's (between -7 and +5 for the four year time horizon, for example), although the magnitude of the difference in mobility does vary with $c$.

It is customary in studies of wage inequality to focus on those with non-zero wages. Table $\mathrm{V}$ presents some results for samples including individuals with zero earnings in the week prior to the interview. Zeros cannot be used when $c=0$ or $c=1$ (due to the logarithm in the expression), nor when $c<0$ (since division by zero would occur) so $c=2$ is used. Furthermore, no attempt is made here to decompose into between and within, due to the difficulty in predicting which individuals will have a zero wage in a given year, and hence in predicting the wage. ${ }^{10}$ The results for total mobility are plotted in Figure 1, with points labelled "c $=2$, withzeros". The

${ }^{10}$ The decomposition could be performed without regressions, but cell sizes would be very small. 
addition of zeros raises inequality and mobility at all time horizons, and reduces or reverses the pattern of increasing inequality and falling mobility over time or age. If $c=0.5$, the addition of zeros also raises inequality and mobility (these results are not shown).

It can be seen in Figure 1 that the profile of mobility against time horizons is affected by the calendar years (or ages) chosen. If the time horizon begins in 1981 and is expanded forward in time, mobility appears to grow more slowly after four years, while if the horizon begins in 1991 and is expanded backward in time, mobility appears to grow steadily with the time horizon. The reason for this is that mobility over, say, a two year horizon is lower at later ages/years, so that when the horizon begins with younger ages and expands forward to include older ages, the mobility growth is slowed by the inclusion of ages/times of lower mobility. The reverse happens when the horizon begins with later ages/times and expands to include mobile young people. The age/time effect thus influences the time horizon effect.

\section{Annual Earnings}

The wage analysis does not take into account inequality originating from differences in annual hours worked. An overview of the results for total mobility is provided in Figure 3 (laid out in the same way as Figure 1). For $c=2$, the total earnings mobility is very similar to wage mobility in all four panels. For $c=0$, however, earnings mobility is much higher than wage mobility, and is higher than the $c=2$ case (although they are not reported, standard errors in the $c=0$ case are very large). The point estimates suggest that movements through the wage and earnings distribution are similar near the top, where full-time full-year workers are likely to be, but that changes in hours cause a lot of mobility lower down the earning distribution, which does not occur in the wage distribution.

When zeros are added to the earnings distribution (for $c=2$ ) mobility falls, contrary to the case of wages. For $c=0.5$ adding zeros does not significantly change mobility (these results are 
not shown), again unlike the case of wages, where mobility rose. With zeros included, mobility is thus higher in the wage than the earnings distribution.

The fact that the addition of zeros to the wage distribution raises inequality by more than the addition of zeros to the earnings distribution provides a clue to the different responses of mobility to the addition of zeros. The distribution of non-zero wages begins only after some threshold (not at one cent per hour), and hence the addition of zeros adds mass to the distribution some distance below the lowest non-zero wage. Large variation in hours worked per year means that in the case of earnings we can think of the addition of zeros as adding mass just below the lowest earnings, which increases inequality less than in the wage case. As for mobility, in the wage case the fact that some individuals are mobile across the relatively large distance between zero and the rest of the distribution causes mobility to rise. In the case of earnings, the fact that on the whole people at zero tend to stay there dominates the effect of the movers, since the movers do not move as far as in the wage case. It appears more natural to add zeros to the earnings distribution as an extension to accounting for variation in hours.

The detailed results for the maximum sample are shown in Tables VI and VII. The point estimates for between mobility are negative for earnings, although generally insignificant. This has no apparent economic interpretation.

Measurement error in the reporting of earnings will show up as mobility. Validation studies of annual earnings in the PSID and the CPS show the standard deviation of the reporting error to be 0.14 and 0.32 respectively (Bound et. al. (1994), Bound and Krueger (1991)). A year of actual earnings can be taken, and other years simulated by assuming that the individual reports randomly from a band of $7 \%$ (or 15\%) on either side of the base year earnings. This simulated data yields mobility measures of at the most 0.005 (or 0.02 ), not large enough to be of importance (that is, measurement error makes inequality appear to be lower by at most 
$2 \%$ over long time horizons). Errors in reporting of annual hours have much larger standard deviations in these studies, and this coupled with inspection of the NLSY hours data led us to reject annual earnings divided by annual hours as a wage measure. Survey week hourly wages may have higher measurement error than annual earnings, but this will not affect the conclusion that, without zeros, wage mobility is similar to or lower than earnings mobility.

The results of Table VI may be compared with those of Shorrocks (1981), who computes the same measures of total mobility for the labor earnings of male household heads in the PSID. For the cohort aged 20-29 at the beginning of his ("consistent") sample in 1967, he finds that the increase in mobility with time horizon begins to level off after six years, rather than four as found here, for $c=0,1$ and 2 . For $c=2$ he finds a fall in inequality of $19 \%$ over four years and $24 \%$ over six years (beginning in 1967), similar to the results of Table VI which show a reduction of $22-25 \%$ and $25-28 \%$ for four and six year horizons (beginning in 1981). For $c=0$ the comparable reductions in Shorrocks are $27 \%$ and $35 \%$ compared to $33-35 \%$ and $37-38 \%$ in this paper (these results are not reported). Thus, the measures are rather similar, despite the different samples and time period.

Shorrocks examines several age cohorts, and finds that the young are more mobile. This suggests that the fall in mobility over time or age found in this part of the paper is likely to be partly an age effect. This issue will be re-examined in the next section.

The analysis in this section was also carried out for men and women separately. For both wages and earnings, the increase in the standard errors indicates that gender differences in mobility are generally not significant (nor are the point estimates very different in magnitude). 


\section{Transition Probabilities and Mobility}

In the previous section we reported the results from the analysis of inequality measures computed over varying time horizons. It can be clearly seen that measures of inequality computed over several years are always smaller than those computed across sectional data. This is undoubtedly the result of changes in one's position in the distribution over time, and is affected by the transitions from one place in the distribution to another that an individual experiences over the period in question.

Therefore, in the current section we examine changes in the transition probabilities over time. We examine staying probabilities by quintiles, as well as the probability of staying outside the distribution. Furthermore, we consider two measures of mobility that summarize the information contained in the transition matrix (i.e., the matrix containing all transition probabilities): (i) the average quintile jump; and (ii) the mean of the reciprocal exit times.

In order to distinguish between changes in the wages and annual earnings, this section is divided into two main parts. We examine the transition probabilities and measure of mobility for annual earnings in the first part, and for hourly wages in the second part. Qualitatively, most of the results obtained for annual earnings are also true for hourly wages. While the estimated probabilities reported here are for white females, the results for white males are essentially the same and are not reported here for brevity.

\subsection{Nonparametric Estimates of Transition Probabilities}

In this part we nonparametrically estimate the probabilities of transition from one quintile to another, as well as the probability of moves between each of the quintiles out of the distribution of annual earnings or wages and vice versa. We employ a straightforward nonparametric kernel 
estimate for the conditional probabilities, while using a data-based method in selecting the kernel bandwidth.

Let $d_{k i}^{t}$ be a dummy variable that defines the quintile an individual was in, at time $t$, that is, $d_{k i}^{t}=1$ if the $i$ th individual was at the $k$ th quintile at time $t$, and $d_{k i}^{t}=0$ otherwise $(k=1, \ldots, 5)$. Similarly, let $d_{0 i}^{t}=1$ if no earnings reported at year $t$ for the $i$ th individual, and $d_{0 i}^{t}=1$ otherwise. For the estimation reported below, only individuals out of school were considered. Therefore, $d_{0}^{t}=0$ means that the individual was either unemployed or out of the labor force; for the analysis here we will not distinguish between the two.

The conditional transition probabilities of interest are

$$
p_{k j}^{t+1}(x) \equiv \operatorname{Pr}\left(d_{k}^{t+1}=1 \mid d_{j}^{t}=1 ; x\right) \quad(k=0,1, \ldots, 5 ; \quad j=0,1, \ldots, 5)
$$

where $x \in \Re^{q}$ is the vector of conditioning variables.

Note that

$$
p_{k j}^{t+1}(x)=\mathrm{E}\left[d_{k}^{t+1}=1 \mid d_{j}^{t}=1 ; x\right]
$$

We can therefore use the Nadaraya-Watson (Nadaraya (1965) and Watson (1964)) kernel estimate for $p_{k j}^{t+1}(x)$ in $(1)$ :

$$
\hat{p}_{k j}^{t+1}(x)=\frac{\sum_{i=1}^{n_{j}} K\left(\left(x-x_{i}\right) / h_{n}\right) d_{k, i}^{t+1} / n h_{n}^{q}}{\sum_{i=1}^{n_{j}} K\left(\left(x-x_{i}\right) / h_{n}\right) / n h_{n}^{q}},
$$

where $n_{j}$ is the number of observations for which $d_{j}^{t}=1, h_{n}$ is the 'bandwidth', and $K(\cdot)$ is a $q$ dimensional kernel function. ${ }^{11}$

A practical problem arises in choosing $h_{n}$. While in theory we need $h_{n}$ such that $h_{n} \rightarrow 0$ as $n \rightarrow 0$, it is well known that in small samples, the estimate $\hat{p}_{k j}(x)$ can be quite sensitive to the

\footnotetext{
${ }^{11}$ In these computations we used the multivariate normal kernel with the kernel weight matrix being a diagonal matrix formed from the sample variance of the conditioning vector $x$. See for example Silverman (1986).
} 
choice of $h_{n}$. We use here the data dependent least-squares (LS) cross-validation technique to choose the optimal $h_{n}$, defined as

$$
h_{n}^{*}=\arg \min _{h}(h)=\arg \min _{h}\left\{\frac{1}{n} \sum_{i=1}^{n_{j}}\left(d_{k i}-\hat{p}_{k j,-i}\left(x_{i}\right)\right)^{2}\right\}
$$

where $\hat{p}_{k j, i}^{t+1}\left(x_{i}\right)$ is the kernel estimate for $p_{k j}^{t+1}\left(x_{i}\right)$, omitting the $i$ th observation from the formula in (2). ${ }^{12}$ The optimal bandwidth $h_{n}^{*}$ is then used in computing the conditional transition probability for several prespecified values of $x$. For the main variables of interest, i.e., education and experience, the values chosen were 8,12 , and 16 years of education and $100,300,500$, and 700 weeks of labor market experience. The other variables included in the analysis are dummy variables for sex and race, and an age variable (reported in full years). The conditional probabilities reported below are evaluated at the median values for these variables.

Note that while one cannot, in general, separate between the age and time effects, the probability estimates are based on the joint distribution of the dependent and independent variables. The joint distribution of age and the other variables need not be the same as that of time and the other variables, and to this extent we are controlling for age and not time effect. The estimated probabilities are conditioned on age and are being examined over time at the same age. If there had not been sufficient richness in the data to obtain precise estimates, the standard errors would have been large; this is not the case in our study as is shown below.

\section{Standard Errors:}

The general formula for the variance of a nonparametric mean function estimate (i.e., $\left.r_{n}(x)=\hat{\mathrm{E}}(y \mid x)\right)$ is given by

$$
\operatorname{Var}\left(r_{n}(x)\right)=\frac{\sigma^{2}(x)}{n h_{n} f(x)} c(K)
$$

\footnotetext{
12 Leaving out the $i$ th observation eliminates the degenerate solution $h_{n}^{*}=0$. Other methods, such as the likelihood cross-validation, yield choices for $h_{n}^{*}$ very similar to the ones obtained here for the LS cross-validation.
} 
where $\sigma^{2}(x)=\operatorname{Var}(Y \mid X=x), c(K)=\int_{\Re 9} K^{2}(u) d u$, and $f(x)$ is the density of the variable $X$ evaluated at the point $X=x$.

In our case this formula simplifies significantly. For $c(K)$ we have $c(K)=(2 \sqrt{\pi})^{-q}$. Incorporating the fact that the dependent variable is a dummy variable (that takes the values of either 0 or 1 ), the conditional variance $\sigma^{2}(x)$ simplifies to

$$
\operatorname{Var}\left(d_{k}^{t+1}=1 \mid d_{j}^{t}=1 ; x\right)=\operatorname{Pr}\left(d_{k}^{t+1}=1 \mid d_{k}^{t}=1 ; x\right)\left[1-\operatorname{Pr}\left(d_{k}^{t+1}=1 \mid d_{k}^{t}=1 ; x\right)\right]
$$

for which a natural estimate is given by $\hat{\sigma}^{2}=\hat{p}_{k j}^{t+1}(x)\left[1-\hat{p}_{k j}^{t+1}(x)\right]$.

An estimate for $f(x)$ is provided by

$$
f_{n}(x)=\frac{1}{n h_{n}^{* q}} \sum_{i=1}^{n_{j}} K\left(\frac{x-x_{i}}{h_{n}^{*}}\right),
$$

where $h_{n}^{*}$ is optimally chosen using the LS cross-validation method.

Similarly, for the covariance terms we have

$$
\operatorname{Cov}\left(\hat{p}_{k j}, \hat{p}_{l j}\right)=-\operatorname{Pr}\left(d_{k}^{t+1}=1 \mid d_{j}^{t+1}=1 ; x\right) \operatorname{Pr}\left(d_{l}^{t+1}=1 \mid d_{j}^{t+1}=1 ; x\right) \cdot\left(c(K) /\left(n h_{n} f(x)\right)\right)
$$

\section{Imposing restrictions on $P$ :}

Note that the elements in each row of the transition matrix $P$ should sum up to 1 , that is

$$
\sum_{j=0}^{5} \hat{p}_{k j}^{t+1}(x)=1 \quad(k=0, \ldots, 5)
$$

Our estimates, $\hat{p}_{k j}^{t+1}(x)$, are unrestricted. We imposed these restrictions using the minimum distance (MD) framework. Let $p=\operatorname{vec}(P)$ be the stacked vector of the rows of $P$, let $\hat{p}$ be the unrestricted estimate of $p$, and let $V_{p}$ be a consistent estimate of its covariance matrix $\Lambda_{p}$. The 36 elements in $p$ can be expressed in terms of only 30 parameters, through the linear restrictions 
$p=G p^{R}$, where $p^{R}$ is a $30 \times 1$ vector and $G$ is a suitable $(36 \times 30)$ restriction matrix. An efficient feasible MD estimate for $p^{R}$ is given by

$$
\hat{p}^{R}=\left(G^{\prime} V_{p}^{-1} G\right)^{-1} G^{\prime} V_{p}^{-1} \hat{p}
$$

This estimate is asymptotically normal with a covariance matrix given by $\Lambda_{p}^{R}=\left(G^{\prime} \Lambda_{p}^{-1} G\right)^{-1}$. The restricted estimate for the vector $p$ is provided then by $\hat{p}^{\mathrm{MD}}=G \hat{p}^{R}$, with $\operatorname{Var}\left(\hat{p}^{\mathrm{MD}}\right)=$ $G \Lambda_{p}^{R} G^{\prime}$

\section{Measures of Mobility:}

In the analysis below we employ two measures of mobility: (a) average jump (or more properly expected jump); and (b) the harmonic mean of the reciprocal mean exit time. The first measure is given by

$$
A J=\frac{\sum_{i=0}^{5} \sum_{j=0}^{5}|i-j| p_{i j} / 6}{A J^{*}}
$$

where $A J^{*}$ is the maximum attainable value for the numerator. (For the $6 \times 6$ transition matrix considered in our study $A J^{*}=4.8$.) This normalization bounds $A J$ between 0 and 1 , where $A J=0$ only if $p_{i j}=1$ for all $i=j$.

The second measure is rather intuitive, but does not take into account the entire transition matrix. Note that $0<p_{i i}<1(i=0, \ldots, 5)$ is the probability of staying within the same quintile, hence, $1 /\left(1-p_{i i}\right)$ is the mean exit time from that quintile. The measure of mobility, $M P$, is defined therefore as

$$
M P=\frac{(6-\operatorname{trace}(P)) / 5}{M P^{*}}=\frac{\sum_{j=0}^{5}\left(1-p_{j j}\right) / 5}{M P^{*}}
$$

where $P$ is the transition matrix between quintiles from time $t$ to time $t+1, \quad p_{j j}(j=0, \ldots, 5)$ are its diagonal elements, and $M P^{*}$ is the maximum attainable value of the numerator of $M P$ $(1.2$ in the case of a $6 \times 6$ matrix $P)$, so that $0 \leq M P \leq 1$. 


\subsection{Analysis of Annual Earnings}

Figure 4 depicts the unconditional staying probabilities for both annual earnings and wages at five quintiles of the distribution, along with the probabilities of staying outside the distribution. As seen in Figure 4a, the unconditional staying probabilities of annual earnings indicate that individuals at the very top of the distribution are more likely to stay there than the individuals at the lower end of the distribution. The staying probability at the top quintile is the highest, exceeding by far the probability of staying in any other quintile. Nevertheless, the probabilities are quite large at the other quintiles as well. Moreover, the staying probabilities at all quintiles have increased enormously over the entire sample period. A fact not seen in the graph is that the transition probabilities became smaller the farther the quintiles are from each other. This will become clearer from the results for the mobility measures below. Interestingly, the second highest probability is that of staying outside the distribution, i.e., having no earnings (or wage). However, this probability is quite different across groups with distinct labor market characteristics, representing the fact that the probability of becoming employed is highly correlated with observed skills, specifically education and experience.

When conditioning the transition probabilities on other variables, things change quite significantly, with wide differences in the levels and the patterns of changes of the probabilities over time among the various skill groups. The results for the staying probabilities of annual earnings are reported in Table VIII for three education groups: elementary school graduates (8 years of education), high school graduates (12 years of education), and college graduates (16 years of education). The staying probabilities for each group are reported at four alternative experience levels $100,300,500$, and 700 weeks. ${ }^{13}$ Some of these conditional probabilities are

\footnotetext{
${ }^{13}$ Note that some of these probabilities are evaluated within the support of the data, while others are predicted probabilities outside the support of the data. These differences are reflected in the reported standard errors, which are larger, in general, for the later probabilities.
} 
also depicted in Figures 5 through 7. Figures 5 depicts the conditional staying probabilities for the elementary school graduates at four levels of experience, while Figures 6 and 7 depict similar graphs for the high school and college graduates, respectively. Each figure includes the staying probabilities at the second, fourth, and fifth quintiles, as well as the probability of staying outside the distribution. ${ }^{14}$

Figure 5 clearly shows that the transition probabilities for the less educated workers are quite volatile, especially at the very top of the distribution. This is evident not only for the new entrants (i.e., those with 100 weeks of experience), but also for the groups with a longer work history. As can be seen from the first panel of Table VIII, the probabilities are estimated rather accurately, so that the large volatility cannot be attributed, in general, to sampling variation.

Figure 6 demonstrates a somewhat clearer pattern of change, especially for the group with longer labor market experience. While the staying probabilities tend to be higher at the higher quintiles, there are smaller differences toward the end of the sample period. This results from consistent increases in the staying probabilities at the lower end of the distribution with no clear trend at the higher quintiles. Regardless of which quintile an individual is in, it becomes less likely for the individual to move out of that quintile, especially for those at the lower quintiles. Even if a move does occur, it has become more likely that the move will be to a closer quintile. The results (not explicitly shown in the tables and figures) indicate that there is very little mobility between the bottom and the top of the annual earnings distribution. The transitions seem to take place mostly among adjacent quintiles at the lower end of the distribution, that is the transition probabilities shrink toward the main diagonal of the transition matrix.

\footnotetext{
14 The transition probabilities for the first and third quintiles are very similar to that of the second quintile and are therefore omitted for clarity of exposition.
} 
The fact that individuals are more likely to remain poor toward the end of the sample period, together with the fact that the increase in real annual earnings was mainly at the top of the distribution, suggests that the increase in wage inequality (either cross-sectional or one that is computed over several years) reflects widening gaps among the same individuals. Note also that the probability of staying outside the distribution (i.e., having no earnings) has a slightly upward trend as well, indicating that those who have no earnings are decreasingly likely to have positive earnings in subsequent periods, let alone having earnings at the higher quintiles of the annual earning distribution. This phenomenon is more pronounced toward the end of the period leading to an even wider gap between the same individuals.

Considering the fact that the probabilities' estimates are conditioned on observed skills, it seems plausible that the market tends to persistently reward unobserved skills, in particular ability, resulting in low and decreasing mobility over time. Comparison of the staying probabilities across the various experience levels shows that the probabilities are, in general, higher for the more experienced than for the less experienced workers, and more so toward the end of the sample period. This, in turn, further supports the conjecture of rewarding unobserved ability, as the more experienced people tend also to have longer tenure on their jobs, and therefore provide longer periods for the employer to observe them.

A similar picture is revealed for the college graduates' group as is demonstrated in Figure 7. First, it is observed that there are, as for the other education groups, substantial differences in the staying probabilities across the five quintiles with larger probabilities at the higher quintiles. However, there are large differences between the probabilities at the higher and lower quintiles for this education group, mainly due to the fact that the probabilities at the higher quintiles are larger for this group than for the other education groups. This, in turn, leads to lower mobility for the more educated groups of workers. 
Interestingly, the probability of being with no earnings at all is persistently high, especially for the less experienced workers. In addition, in results not shown, the probabilities of entering the distribution at high quintiles are quite small, and more so toward the end of the sample period. If having no earnings meant that an individual were unemployed, then this finding would indicate that even an individual with a relatively high level of education can find it more difficult to find a job than an individual with lower observed education. This is mitigated, however, by the fact that in the sample used here individuals with no earnings might have been out of the labor force.

\section{Measures of mobility:}

In Table IX we report the results (for a few selected years) for two measures of mobility: average quintile jump $(A J)$, and mean of the reciprocal exit times $(M P)$ (defined in (3) and (4), respectively), for the same three education groups analyzed above. The results for the $A J$ and $M P$ measures are also depicted in Figures 8 and 9 , respectively.

A few important results are apparent from Figure 8 for the AJ measure. There was a general continuous decline in the $A J$ measure of mobility representing the fact that the transition probabilities were shrinking toward the main diagonal of the transition matrix. Some differences can be detected among the measures across the various education-experience groups. At any level of labor market experience, mobility is typically larger for the less educated individuals, especially toward the end of the period. Comparison across the various experience levels, at the same level of education, shows that there are smaller differences across experience levels than across education levels. However, mobility tends to be somewhat higher for the less experienced individuals, and more pronouncedly so for the less educated individuals.

It is apparent that the $\mathrm{AJ}$ measures of the various education-experience groups are farther 
away from each other toward the end of the period, and more so for the more experienced groups. The variability in the average jump statistic tends to be much larger for the less skilled groups, but as is apparent from Table IX it is only partially due to sampling variation.

Figure 9 presents the results for the mean of the reciprocal exit times $(M P)$, and is organized in the same fashion as Figure 8. While the $A J$ measure takes into account the off-diagonal probabilities of the transition matrix, the $M P$ measure is based, as described above, only on the diagonal elements of the transition matrix (i.e., the transition probabilities between different quintiles), and is therefore, by itself, less informative. The larger the diagonal terms of the transition matrix $P$ the lower the mobility and the smaller is $M P . M P$ approaches 0 as the diagonal terms (i.e., the staying probabilities) approach 1.

Figures 9a through 9c (for the three levels of experience) indicate similar trends in the MP measures to the AJ measures depicted in Figure 8. As for the $A J$ measure there is clear ordering among the $M P$ measures across the various education groups. In particular, the $M P$ measure is smaller (i.e., indicates less mobility) for the more skilled individuals, especially toward the end of the sample period. This ordering is somewhat sharper than for the $\mathrm{AJ}$ measure, reflecting the fact that the off-diagonal transition probabilities are more spread across the different quintiles for the more skilled individuals, but the diagonal terms are larger as well. That is, the staying probabilities are larger for the more skilled groups, but conditional on moving, the moves are larger.

The similarities in the AJ and MP measures indicate that the staying probabilities and moving probabilities to adjacent quintiles account for most of the moves through the earnings distribution. Sharp increases in the former probabilities, especially those at the lower quintiles, indicate that the poor are more likely to remain poor and increasingly so toward the end of the sample period. 


\subsection{Analysis of Wages}

The results in the previous section indicate major changes in the degree and pattern of mobility for annual earnings. There is a question though still to be answered: what are the sources of these apparent changes? Can these changes be attributed to differential changes across skill groups in the supply of labor (i.e, hours worked)? Or, alternatively: to what extent are the changes in mobility due to changes in the wage rate (i.e., the wages paid per hour of work)? The purpose of this section is to examine which of the two effects was more influential in affecting the changes we documented for annual earnings.

Table $\mathrm{X}$ reports the results for the estimation carried out for hourly wages. The procedure followed is exactly the same as that described for annual carnings. As can be clearly seen from Figure $4 \mathrm{~b}$ the unconditional staying probabilities for wages demonstrate the same general pattern of changes and ordering as for annual earnings. The staying probabilities at all quintiles and outside the distribution are somewhat lower for wages than for annual earnings. Moreover, they have increased in a smoother and more continuous fashion for wages, with much less variation over time.

Similar differences to those revealed for the unconditional probabilities are apparent for the conditional probabilities. Moreover, the pattern of changes for these probabilities is quite similar to those observed for annual earnings. Nonetheless, a few important findings are worth noting: (a) the variability over time of the transition probabilities are significantly larger for wages than for annual earnings; (b) there is much more stability in the transition probabilities for the more educated, more experienced individuals; and (c) for any level of education and at any level of experience, the staying probabilities (as well as the off-diagonal terms) are less 
variable at the higher quintiles than at the lower quintiles. ${ }^{15}$

Some of the more substantial differences in the mobility of wages and annual earnings are apparent from the results for the $A J$ and $M P$ measures. The results for these two measures are reported in Table XI and are graphed in Figures 10 (for the AJ measure) and Figure 11 (for the MP measure). These figures depict the conditional measures of mobility for the same three education groups discussed above, at a few levels of experience, along with the unconditional measures.

As can be seen from these graphs, the general trends of the $A J$ and $M P$ measures are similar to those of annual earnings. However, the ordering of these measures are less pronounced for wages than they are for annual earnings, and the variability in these measures is much larger for wages than for annual earnings. Significant variations in the mobility measures are especially apparent for the least educated individuals, even those with relatively long labor market experience. Nevertheless, the standard errors of these measures are quite large as well. No clear ordering is apparent for the other two education groups at any given level of labor market experience. However, the general picture revealed is of higher mobility in wages for more highly educated individuals.

Note that, in general, the $A J$ measures for wages are larger than those for annual earnings by more than the $M P$ measures. This indicates that the staying probability for annual earnings are larger, but more importantly it indicates that conditional on moving, the moves in wages are larger than those for annual earnings. The fact that there is more mobility in wages than in annual earnings implies that the number of hours worked changes in the reverse direction to changes in wages, which keeps annual earnings less mobile than wages. That is, individuals adjust their hours of work to compensate for changes in their relative wages. Overall, the

\footnotetext{
15 While the relevant figures are omitted for brevity, they are available from the authors upon request.
} 
induced changes of hours worked somewhat offset the changes in the relative wages.

\section{Summary and Conclusions}

The vast changes in the U.S. wage structure have attracted much research over the past few years. Studies that examined changes in earnings, income, and wages concluded, by and large, that the distributions of these variables have expanded considerably, leading to larger variances and significant increases in the inequality measures computed for these distributions, especially in the 1980s. Furthermore, studies that modeled the error component of the earnings, income, and wage distributions reached, by and large, the conclusion that there were significant increases in both the transitory and the permanent components of these distributions.

In this study we use data from the National Longitudinal Survey of Youth (NLSY) in analyzing more specific questions regarding the changes in the earnings and wage distributions. Particularly, in the first part of the analysis we exploit the panel structure of the NLSY to examine measures of wage and earning inequality, computed over different time horizons, and decompose them into between and within components. In the second part we nonparametrically estimate transition probabilities between quintiles of the distributions in order to be able to assess the impact and implications of the observed changes in inequality.

The results from the first part indicate that mobility of individuals through the wage distribution over time means that inequality measured over time horizons longer than a year is somewhat lower than the average yearly inequality. This mobility occurs mainly within groups of individuals with the same observable characteristics, while mobility between groups is generally statistically insignificant.

Within group mobility rises most rapidly over horizons up to four years, reducing wage 
inequality by between $12 \%$ and $26 \%$, depending principally upon the age of the workers. This suggests that although an important part of wage inequality is due to short-term shocks which do not persist longer than four years, the larger part is due to longer term causes. The within group inequality that persists may be due to unobservable characteristics of individuals.

Mobility through the earnings distribution is higher than mobility through the wage distribution for measures of inequality weighting more heavily inequality lower down the distribution. Mobility rises when individuals with zero wages are included in the wage distribution, and falls or stays the same when zeros are added to earnings, depending upon which part of the distribution is weighted more heavily.

In the second part of the study we characterize movement of individuals through the distributions of both earnings and wages. Specifically, we estimate transition probabilities between quintiles as well as the probabilities of moving in and out of the wage (and earnings) distribution.

While differences among individuals with distinct observed characteristics, mainly education and experience, do exist, several features are common to all individuals. The most important finding is the convergence of the probabilities toward the main diagonal of the transition matrix. There is a significant increase in the staying probabilities at each and every quintile, most pronouncedly at the low quintiles. It is also apparent that the farther away the quintiles are from each other (i.e., the farther an element is from the main diagonal), the smaller the probability becomes over the years.

Analysis of two measures of mobility which are based on the transition probabilities matrix indicates a sharp decrease in mobility over time, across all skill groups. Rising inequality and falling mobility together create an increased gap over time between any two individuals who have the same observed skills.

The most important findings of this study can be described as follows: it may seem that the 
increasing wage inequality, computed from cross section data sets, need not worry economists as much as they do; evidently inequality measures computed over longer time horizons are somewhat smaller. However, examination of mobility measures shows that mobility has fallen significantly over time. This resulted from: (a) sharp increase in the staying probability at each point of the wage (and earnings) distribution, especially at the bottom part of the distribution; and (b) significant decrease in the transition probabilities between points in the distribution which are far apart from each other. 


\section{References}

Abowd, J.M. and D. Card (1989): "On the Covariance Structure of Earnings and Hours Changes," Econometrica, 57, pp.411-445.

Atkinson, A.B., Bourguignon and C. Morrisson (1992): Empirical Studies of Earnings Mobility, Philadelphia: Harwood Academic Publishers.

Bound, J., Brown, C., Duncan, G. and W. Rodgers (1994): "Evidence on the Validity of Cross-sectional and Longitudinal Labor Market Data," Journal of Labor Economics, 12, pp.345-368.

Bound, J. and A. Krueger (1991): "The Extent of Measurement Error in Longitudinal Earnings Data: Do Two Wrongs Make a Right?" Journal of Labor Economics, 9, pp.1-24.

Howes, S. and J. Lanjouw (1995): "Making Poverty Comparisons Taking into Account Survey Design: How and Why," Unpublished manuscript.

Katz, L. and K. Murphy (1992): "Changes in Relative Wages, 1963-1987: Supply and Demand Factors," Quarterly Journal of Economics, pp. 35-78.

Katz, L., Loveman, G. and D.Blanchflower (1995). "A Comparison of Changes in the Structure of Wages." In Freeman, R. and L.Katz ed., Differences and Changes in Wage Structures, Chicago: University of Chicago Press.

Levy, F. and R. Murnane (1992): "U.S. Earnings Levels and Earnings Inequality: A Review of Recent Trends and Proposed Explanations," Journal of Economic Literature, 30, pp. 333-381.

Lillard, L.A and Y. Weiss (1979): "Components of Variation in Panel Earnings Data: American Scientists 1960-1970," Econometrica, 47, pp. 437-454.

Lillard, L.A. and R.J. Willis (1978): "Dynamic Aspects of Earnings Mobility," Econometrica, 46, pp. 985-1012.

Maasoumi, E. and S. Zandvakili (1990): "Generalized Entropy Meaures of Mobility for Different Sexes and Income Levels," Journal of Econometrics, 43, pp. 121-133.

MaCurdy, T.E. (1982): "The Use of Time Series Processes to Model the Error Structure of Earnings in a Longitudinal Data Analysis," Journal of Econometrics, 18, pp.83-114.

Moffitt, R. and P. Gottschalk (1993): "Trends in the Covariance of Earnings in the United States: 1969-1987," Institute for Research on Poverty, Discussion paper No. 1001-93.

Morduch, J. and T. Sicular (1994): "Rethinking Inequality Decomposition, with an Application to Rural China," Unpublished manuscript.

Nadaraya, E.A. (1965): "On Nonparametric Estimation of Density Function and Regression," Theory of Probability and its Application, 10, 186-190.

Shorrocks, A.F. (1981): "Income Stability in the United States," in N.A.Klevmarken and J.A.Lybeck eds. The Statics and Dynamics of Income. Clevedon, Tieto. 
Shorrocks, A.F. (1984): "Inequality Decomposition by Population Subgroups," Econometrica, 52, pp.1369- 1385 .

Silverman, B.W. (1986): Density Estimation for Statistics and Data Analysis, New York: Chapman and Hall.

Watson, G.S. (1964): "Smooth Regression Analysis," Sankhyā, Series A, 26, 359-372. 
Table I: A vailable NLSY Data by Earnings and Wages

\begin{tabular}{|c|c|c|c|c|c|c|c|c|c|}
\hline \multirow[b]{2}{*}{ Year } & \multicolumn{2}{|c|}{ Used } & \multicolumn{6}{|c|}{ Omitted } & \multirow[b]{2}{*}{$\begin{array}{r}\text { Tota } \\
\text { Omitted }\end{array}$} \\
\hline & $>0$ & $=0$ & $\begin{array}{r}\text { Self } \\
\text { Empl. }\end{array}$ & Military & $\begin{array}{r}\text { In } \\
\text { School } \\
\end{array}$ & $\begin{array}{r}\text { Non- } \\
\text { interview } \\
\end{array}$ & $\begin{array}{r}\text { No } \\
\text { Grade } \\
\end{array}$ & Missing & \\
\hline \multicolumn{10}{|c|}{ Earnings: } \\
\hline 1979 & 2721 & 586 & 222 & 1313 & 7798 & 545 & 24 & 85 & 9902 \\
\hline 1980 & 3708 & 865 & 284 & 1248 & 6427 & 491 & 24 & 106 & 8474 \\
\hline 1981 & 4614 & 1039 & 390 & 1207 & 5234 & 563 & 24 & 100 & 7418 \\
\hline 1982 & 5482 & 1335 & 465 & 1178 & 4090 & 465 & 24 & 92 & 6222 \\
\hline 1983 & 6273 & 1482 & 426 & 1091 & 3048 & 617 & 24 & 99 & 5206 \\
\hline 1984 & 6415 & 1318 & 422 & 614 & 2412 & 1792 & 24 & 98 & 5264 \\
\hline 1985 & 6657 & 1304 & 437 & 578 & 1741 & 2031 & 24 & 131 & 4811 \\
\hline 1986 & 6669 & 1377 & 427 & 515 & 1435 & 2201 & 24 & 231 & 4602 \\
\hline 1987 & 7012 & 1356 & 496 & 476 & 1170 & 2221 & 24 & 131 & 4387 \\
\hline 1988 & 7022 & 1382 & 551 & 430 & 1131 & 2081 & 24 & 219 & 4217 \\
\hline 1989 & 7056 & 1386 & 520 & 377 & 995 & 2250 & 24 & 214 & 4166 \\
\hline 1990 & 6122 & 1218 & 449 & 323 & 969 & 3668 & 24 & 164 & 5433 \\
\hline \multicolumn{10}{|c|}{ Wages: } \\
\hline 1980 & 3023 & 1998 & 146 & 994 & 5986 & 545 & 24 & 82 & 7695 \\
\hline 1981 & 3838 & 2566 & 161 & 855 & 4744 & 491 & 24 & 97 & 6275 \\
\hline 1982 & 4407 & 2978 & 256 & 825 & 3622 & 563 & 24 & 140 & 5290 \\
\hline 1983 & 5028 & 3376 & 301 & 780 & 2626 & 465 & 24 & 183 & 4196 \\
\hline 1984 & 5721 & 3082 & 368 & 707 & 2078 & 617 & 24 & 190 & 3794 \\
\hline 1985 & 5726 & 2795 & 401 & 400 & 1451 & 1792 & 24 & 148 & 4068 \\
\hline 1986 & 6004 & 2594 & 446 & 328 & 1154 & 2031 & 24 & 157 & 3983 \\
\hline 1987 & 6279 & 2505 & 523 & 302 & 754 & 2201 & 24 & 148 & 3804 \\
\hline 1988 & 6388 & 2498 & 588 & 254 & 599 & 2221 & 24 & 162 & 3686 \\
\hline 1989 & 6413 & 2628 & 636 & 249 & 498 & 2081 & 24 & 195 & 3488 \\
\hline 1990 & 6399 & 2506 & 638 & 211 & 527 & 2250 & 24 & 170 & 3650 \\
\hline 1991 & 5292 & 2403 & 593 & 184 & 410 & 3668 & 24 & 162 & 4879 \\
\hline
\end{tabular}

Note: The sum of columns 2,3 and 10 exceeds 12686 , the total number of observations in the National Longitudinal Survey of Youth (NLSY) since an observation might be omitted from the analysis for more than one criteria. 
TABLE II: Inequality and Mobility for Wages

Maximum Sample, $c=0$

\begin{tabular}{|c|c|c|c|c|c|c|c|}
\hline \multirow[t]{2}{*}{ Year } & \multirow[t]{2}{*}{$N$} & \multicolumn{3}{|c|}{ Inequality } & \multicolumn{3}{|c|}{ Mobility } \\
\hline & & Total & Between & Within & Total & Between & Within \\
\hline 1981 & 3768 & $\begin{array}{c}7.4 \\
(0.4)\end{array}$ & $\begin{array}{c}1.5 \\
(0.1)\end{array}$ & $\begin{array}{c}5.9 \\
(0.4)\end{array}$ & & & \\
\hline 1983 & 4894 & $\begin{array}{c}8.8 \\
(0.4)\end{array}$ & $\begin{array}{c}2.0 \\
(0.1)\end{array}$ & $\begin{array}{c}6.7 \\
(0.5)\end{array}$ & & & \\
\hline 1985 & 5607 & $\begin{array}{c}9.3 \\
(0.4)\end{array}$ & $\begin{array}{c}2.5 \\
(0.1)\end{array}$ & $\begin{array}{c}6.9 \\
(0.4)\end{array}$ & & & \\
\hline 1987 & 6159 & $\begin{array}{c}11.0 \\
(0.5)\end{array}$ & $\begin{array}{c}2.9 \\
(0.1)\end{array}$ & $\begin{array}{c}8.1 \\
(0.5)\end{array}$ & & & \\
\hline 1989 & 6287 & $\begin{array}{c}12.1 \\
(0.5)\end{array}$ & $\begin{array}{c}3.1 \\
(0.1)\end{array}$ & $\begin{array}{c}8.9 \\
(0.6)\end{array}$ & & & \\
\hline 1991 & 5189 & $\begin{array}{r}12.4 \\
(0.6) \\
\end{array}$ & $\begin{array}{c}3.4 \\
(0.2) \\
\end{array}$ & $\begin{array}{r}9.0 \\
(0.7) \\
\end{array}$ & & & \\
\hline $81-82$ & 2556 & $\begin{array}{c}6.4 \\
(0.3)\end{array}$ & $\begin{array}{c}1.5 \\
(0.1)\end{array}$ & $\begin{array}{c}4.8 \\
(0.4)\end{array}$ & $\begin{array}{c}14.8 \\
(1.3)\end{array}$ & $\begin{array}{c}1.2 \\
(0.8)\end{array}$ & $\begin{array}{c}18.4 \\
(1.5)\end{array}$ \\
\hline $84-85$ & 3885 & $\begin{array}{c}7.9 \\
(0.4)\end{array}$ & $\begin{array}{c}2.2 \\
(0.1)\end{array}$ & $\begin{array}{c}5.6 \\
(0.4)\end{array}$ & $\begin{array}{c}11.5 \\
(0.9)\end{array}$ & $\begin{array}{c}1.0 \\
(0.5)\end{array}$ & $\begin{array}{l}15.0 \\
(1.1)\end{array}$ \\
\hline $87-88$ & 4650 & $\begin{array}{c}9.6 \\
(0.5)\end{array}$ & $\begin{array}{c}2.7 \\
(0.1)\end{array}$ & $\begin{array}{c}6.9 \\
(0.5)\end{array}$ & $\begin{array}{c}10.4 \\
(0.9)\end{array}$ & $\begin{array}{c}0.8 \\
(0.5)\end{array}$ & $\begin{array}{l}13.7 \\
(1.0)\end{array}$ \\
\hline $90-91$ & 4100 & $\begin{array}{c}10.6 \\
(0.5) \\
\end{array}$ & $\begin{array}{c}3.2 \\
(0.2) \\
\end{array}$ & $\begin{array}{c}7.4 \\
(0.6) \\
\end{array}$ & $\begin{array}{c}7.2 \\
(0.9) \\
\end{array}$ & $\begin{array}{c}0.6 \\
(0.5) \\
\end{array}$ & $\begin{array}{r}9.8 \\
(1.1) \\
\end{array}$ \\
\hline $81-84$ & 1585 & $\begin{array}{c}5.7 \\
(0.4)\end{array}$ & $\begin{array}{c}1.4 \\
(0.1)\end{array}$ & $\begin{array}{c}4.3 \\
(0.4)\end{array}$ & $\begin{array}{c}23.5 \\
(1.7)\end{array}$ & $\begin{array}{c}2.3 \\
(1.3)\end{array}$ & $\begin{array}{c}28.7 \\
(2.1)\end{array}$ \\
\hline $84-87$ & 2546 & $\begin{array}{c}7.4 \\
(0.4)\end{array}$ & $\begin{array}{c}2.3 \\
(0.2)\end{array}$ & $\begin{array}{c}5.2 \\
(0.5)\end{array}$ & $\begin{array}{c}19.6 \\
(1.3)\end{array}$ & $\begin{array}{c}1.9 \\
(0.9)\end{array}$ & $\begin{array}{c}25.5 \\
(1.6)\end{array}$ \\
\hline $88-91$ & 2733 & $\begin{array}{c}9.0 \\
(0.5) \\
\end{array}$ & $\begin{array}{c}2.8 \\
(0.2) \\
\end{array}$ & $\begin{array}{c}6.2 \\
(0.5) \\
\end{array}$ & $\begin{array}{c}13.5 \\
(1.1) \\
\end{array}$ & $\begin{array}{c}0.4 \\
(0.7) \\
\end{array}$ & $\begin{array}{c}18.4 \\
(1.2) \\
\end{array}$ \\
\hline $81-86$ & 1022 & $\begin{array}{c}5.5 \\
(0.5)\end{array}$ & $\begin{array}{c}1.4 \\
(0.2)\end{array}$ & $\begin{array}{c}4.1 \\
(0.5)\end{array}$ & $\begin{array}{c}25.3 \\
(2.0)\end{array}$ & $\begin{array}{c}2.1 \\
(1.4)\end{array}$ & $\begin{array}{c}30.8 \\
(2.4)\end{array}$ \\
\hline $86-91$ & 1748 & $\begin{array}{c}8.0 \\
(0.5)\end{array}$ & $\begin{array}{c}2.5 \\
(0.2)\end{array}$ & $\begin{array}{c}5.5 \\
(0.6) \\
\end{array}$ & $\begin{array}{c}18.0 \\
(1.3)\end{array}$ & $\begin{array}{c}1.7 \\
(0.9)\end{array}$ & $\begin{array}{c}23.8 \\
(1.5)\end{array}$ \\
\hline $81-88$ & 726 & $\begin{array}{c}5.8 \\
(0.6)\end{array}$ & $\begin{array}{c}1.3 \\
(0.2)\end{array}$ & $\begin{array}{c}4.5 \\
(0.7)\end{array}$ & $\begin{array}{c}26.5 \\
(2.3)\end{array}$ & $\begin{array}{c}3.2 \\
(1.9)\end{array}$ & $\begin{array}{c}31.1 \\
(2.8)\end{array}$ \\
\hline $84-91$ & 1074 & $\begin{array}{c}7.2 \\
(0.6)\end{array}$ & $\begin{array}{c}2.2 \\
(0.2)\end{array}$ & $\begin{array}{c}5.0 \\
(0.7)\end{array}$ & $\begin{array}{c}22.1 \\
(1.8)\end{array}$ & $\begin{array}{c}3.2 \\
(1.4)\end{array}$ & $\begin{array}{c}28.3 \\
(2.1)\end{array}$ \\
\hline $82-91$ & 546 & $\begin{array}{c}6.1 \\
(0.7)\end{array}$ & $\begin{array}{c}1.7 \\
(0.3)\end{array}$ & $\begin{array}{c}4.5 \\
(0.8) \\
\end{array}$ & $\begin{array}{c}26.6 \\
(2.7) \\
\end{array}$ & $\begin{array}{c}5.3 \\
(2.5) \\
\end{array}$ & $\begin{array}{r}32.3 \\
(3.4)\end{array}$ \\
\hline
\end{tabular}

Notes:

1. The wage measure is the hourly wage earned on the main job last week, deflated by the implicit price deflator for personal consumption expenditure.

2. The sample used for each measure consists of all civilian individuals neither in school nor self-employed with valid non-zero wages for the time periods relevant for that particular measure.

3. Inequality is measured using the generalized entropy measure with the inequality aversion parameter set to 0 .

4. All coefficients and standard errors are multiplied by 100 . 
TABLE III: Inequality and Mobility for Wages Consistent Sample, $c=0$

\begin{tabular}{|c|c|c|c|c|c|c|c|}
\hline \multirow[t]{2}{*}{ Year } & \multirow[t]{2}{*}{$N$} & \multicolumn{3}{|c|}{ Inequality } & \multicolumn{3}{|c|}{ Mobility } \\
\hline & & Total & Between & Within & Total & Between & Within \\
\hline 1981 & 381 & $\begin{array}{c}6.8 \\
(0.9)\end{array}$ & $\begin{array}{c}1.3 \\
(0.3)\end{array}$ & $\begin{array}{c}5.5 \\
(1.0)\end{array}$ & & & \\
\hline 1983 & 381 & $\begin{array}{c}7.4 \\
(1.0)\end{array}$ & $\begin{array}{c}1.2 \\
(0.3)\end{array}$ & $\begin{array}{c}6.3 \\
(1.1)\end{array}$ & & & \\
\hline 1985 & 381 & $\begin{array}{c}7.4 \\
(1.3)\end{array}$ & $\begin{array}{c}1.5 \\
(0.4)\end{array}$ & $\begin{array}{c}6.0 \\
(1.4)\end{array}$ & & & \\
\hline 1987 & 381 & $\begin{array}{c}8.9 \\
(1.4)\end{array}$ & $\begin{array}{c}1.7 \\
(0.4)\end{array}$ & $\begin{array}{c}7.2 \\
(1.5)\end{array}$ & & & \\
\hline 1989 & 381 & $\begin{array}{c}9.7 \\
(1.8)\end{array}$ & $\begin{array}{c}1.7 \\
(0.4)\end{array}$ & $\begin{array}{c}8.0 \\
(1.9)\end{array}$ & & & \\
\hline 1991 & 381 & $\begin{array}{c}7.4 \\
(1.1) \\
\end{array}$ & $\begin{array}{c}1.7 \\
(0.4) \\
\end{array}$ & $\begin{array}{c}5.7 \\
(1.2) \\
\end{array}$ & & & \\
\hline $81-82$ & 381 & $\begin{array}{c}6.1 \\
(0.8)\end{array}$ & $\begin{array}{c}1.3 \\
(0.3)\end{array}$ & $\begin{array}{c}4.8 \\
(0.9)\end{array}$ & $\begin{array}{c}12.6 \\
(3.3)\end{array}$ & $\begin{array}{c}2.9 \\
(2.4)\end{array}$ & $\begin{array}{c}14.9 \\
(3.9)\end{array}$ \\
\hline $84-85$ & 381 & $\begin{array}{c}6.9 \\
(1.2)\end{array}$ & $\begin{array}{c}1.3 \\
(0.3)\end{array}$ & $\begin{array}{c}5.6 \\
(1.3)\end{array}$ & $\begin{array}{c}6.6 \\
(1.7)\end{array}$ & $\begin{array}{c}0.3 \\
(1.4)\end{array}$ & $\begin{array}{c}8.0 \\
(2.2)\end{array}$ \\
\hline $87-88$ & 381 & $\begin{array}{c}7.3 \\
(1.1)\end{array}$ & $\begin{array}{c}1.7^{\prime} \\
(0.4)\end{array}$ & $\begin{array}{c}5.7 \\
(1.3)\end{array}$ & $\begin{array}{c}8.5 \\
(2.0)\end{array}$ & $\begin{array}{c}1.3 \\
(1.3)\end{array}$ & $\begin{array}{c}10.4 \\
(2.2)\end{array}$ \\
\hline $90-91$ & 381 & $\begin{array}{c}7.2 \\
(1.0) \\
\end{array}$ & $\begin{array}{c}1.7 \\
(0.4) \\
\end{array}$ & $\begin{array}{c}5.5 \\
(1.1) \\
\end{array}$ & $\begin{array}{c}6.9 \\
(1.9) \\
\end{array}$ & $\begin{array}{c}0.9 \\
(1.2) \\
\end{array}$ & $\begin{array}{c}8.6 \\
(2.2) \\
\end{array}$ \\
\hline $81-84$ & 381 & $\begin{array}{c}5.6 \\
(0.7)\end{array}$ & $\begin{array}{c}1.2 \\
(0.3)\end{array}$ & $\begin{array}{c}4.4 \\
(0.7)\end{array}$ & $\begin{array}{c}22.5 \\
(3.6)\end{array}$ & $\begin{array}{c}3.8 \\
(3.1)\end{array}$ & $\begin{array}{l}26.3 \\
(4.5)\end{array}$ \\
\hline $84-87$ & 381 & $\begin{array}{c}6.6 \\
(1.0)\end{array}$ & $\begin{array}{c}1.5 \\
(0.3)\end{array}$ & $\begin{array}{c}5.1 \\
(1.1)\end{array}$ & $\begin{array}{l}16.6 \\
(2.9)\end{array}$ & $\begin{array}{c}1.3 \\
(1.9)\end{array}$ & $\begin{array}{c}20.2 \\
(3.4)\end{array}$ \\
\hline $88-91$ & 381 & $\begin{array}{c}7.1 \\
(1.0)\end{array}$ & $\begin{array}{c}1.7 \\
(0.4)\end{array}$ & $\begin{array}{c}5.4 \\
(1.1)\end{array}$ & $\begin{array}{r}12.5 \\
(2.8) \\
\end{array}$ & $\begin{array}{c}1.0 \\
(2.0) \\
\end{array}$ & $\begin{array}{r}15.6 \\
(3.4) \\
\end{array}$ \\
\hline $81-86$ & 381 & $\begin{array}{c}5.6 \\
(0.8)\end{array}$ & $\begin{array}{c}1.3 \\
(0.3)\end{array}$ & $\begin{array}{c}4.3 \\
(0.9)\end{array}$ & $\begin{array}{l}24.0 \\
(3.2)\end{array}$ & $\begin{array}{c}4.4 \\
(2.6)\end{array}$ & $\begin{array}{c}28.3 \\
(3.8)\end{array}$ \\
\hline $86-91$ & 381 & $\begin{array}{c}6.9 \\
(1.0) \\
\end{array}$ & $\begin{array}{c}1.7 \\
(0.3)\end{array}$ & $\begin{array}{c}5.2 \\
(1.1)\end{array}$ & $\begin{array}{r}15.6 \\
(2.5)\end{array}$ & $\begin{array}{c}1.1 \\
(1.8)\end{array}$ & $\begin{array}{c}19.4 \\
(3.0) \\
\end{array}$ \\
\hline $81-88$ & 381 & $\begin{array}{c}5.5 \\
(0.8)\end{array}$ & $\begin{array}{c}1.3 \\
(0.3)\end{array}$ & $\begin{array}{c}4.2 \\
(0.9)\end{array}$ & $\begin{array}{c}26.3 \\
(3.1)\end{array}$ & $\begin{array}{c}5.1 \\
(2.6)\end{array}$ & $\begin{array}{c}31.1 \\
(3.7)\end{array}$ \\
\hline 84-91 & 381 & $\begin{array}{c}6.4 \\
(0.9) \\
\end{array}$ & $\begin{array}{c}1.6 \\
(0.3)\end{array}$ & $\begin{array}{c}4.8 \\
(1.0)\end{array}$ & $\begin{array}{r}19.8 \\
(2.8)\end{array}$ & $\begin{array}{c}1.2 \\
(2.1)\end{array}$ & $\begin{array}{c}24.5 \\
(3.5)\end{array}$ \\
\hline $82-91$ & 381 & $\begin{array}{c}6.0 \\
(0.9)\end{array}$ & $\begin{array}{c}1.5 \\
(0.3)\end{array}$ & $\begin{array}{c}4.5 \\
(1.0)\end{array}$ & $\begin{array}{r}24.4 \\
(3.0) \\
\end{array}$ & $\begin{array}{c}2.0 \\
(2.3)\end{array}$ & $\begin{array}{c}29.7 \\
(3.6)\end{array}$ \\
\hline
\end{tabular}

Notes:

1. The wage measure is the hourly wage earned on the main job last week, deflated by the implicit price deflator for personal consumption expenditure.

2. The sample consists of civilian individuals neither in school nor self-employed with valid non-zero wages for the years 1981-1991.

3. Inequality is measured using the generalized entropy measure with the inequality aversion parameter set to 0 .

4. All coefficients and standard errors are multiplied by 100 . 
TABLE IV: Inequality and Mobility for Wages Maximum Sample, $c=2$

\begin{tabular}{|c|c|c|c|c|c|c|c|}
\hline \multirow[t]{2}{*}{ Year } & \multirow[t]{2}{*}{$N$} & \multicolumn{3}{|c|}{ Inequality } & \multicolumn{3}{|c|}{ Mobility } \\
\hline & & Total & Between & Within & Total & Between & Within \\
\hline 1981 & 3768 & $\begin{array}{c}9.3 \\
(0.4)\end{array}$ & $\begin{array}{c}1.5 \\
(0.1)\end{array}$ & $\begin{array}{c}7.8 \\
(0.5)\end{array}$ & & & \\
\hline 1983 & 4894 & $\begin{array}{c}10.7 \\
(0.4)\end{array}$ & $\begin{array}{c}2.1 \\
(0.2)\end{array}$ & $\begin{array}{c}8.7 \\
(0.5)\end{array}$ & & & \\
\hline 1985 & 5607 & $\begin{array}{c}10.3 \\
(0.4)\end{array}$ & $\begin{array}{c}2.5 \\
(0.2)\end{array}$ & $\begin{array}{c}7.7 \\
(0.5)\end{array}$ & & & \\
\hline 1987 & 6159 & $\begin{array}{c}13.1 \\
(0.5)\end{array}$ & $\begin{array}{c}3.0 \\
(0.2)\end{array}$ & $\begin{array}{c}10.1 \\
(0.6)\end{array}$ & & & \\
\hline 1989 & 6287 & $\begin{array}{c}15.5 \\
(0.5)\end{array}$ & $\begin{array}{c}3.1 \\
(0.2)\end{array}$ & $\begin{array}{c}12.3 \\
(0.6)\end{array}$ & & & \\
\hline 1991 & 5189 & $\begin{array}{c}18.1 \\
(0.7) \\
\end{array}$ & $\begin{array}{c}3.5 \\
(0.2) \\
\end{array}$ & $\begin{array}{l}14.6 \\
(0.8) \\
\end{array}$ & & & \\
\hline $81-82$ & 2556 & $\begin{array}{c}7.5 \\
(0.4)\end{array}$ & $\begin{array}{c}1.5 \\
(0.1)\end{array}$ & $\begin{array}{c}5.9 \\
(0.5)\end{array}$ & $\begin{array}{c}17.4 \\
(1.0)\end{array}$ & $\begin{array}{c}1.2 \\
(0.9)\end{array}$ & $\begin{array}{c}20.8 \\
(1.3)\end{array}$ \\
\hline $84-85$ & 3885 & $\begin{array}{c}8.8 \\
(0.4)\end{array}$ & $\begin{array}{c}2.3 \\
(0.2)\end{array}$ & $\begin{array}{c}6.5 \\
(0.5)\end{array}$ & $\begin{array}{c}11.4 \\
(0.6)\end{array}$ & $\begin{array}{c}1.0 \\
(0.7)\end{array}$ & $\begin{array}{c}14.5 \\
(0.9)\end{array}$ \\
\hline $87-88$ & 4650 & $\begin{array}{c}11.6 \\
(0.5)\end{array}$ & $\begin{array}{c}2.8 \\
(0.2)\end{array}$ & $\begin{array}{c}8.8 \\
(0.6)\end{array}$ & $\begin{array}{c}12.5 \\
(0.6)\end{array}$ & $\begin{array}{c}0.9 \\
(0.6)\end{array}$ & $\begin{array}{l}15.6 \\
(0.8)\end{array}$ \\
\hline $90-91$ & 4100 & $\begin{array}{l}12.6 \\
(0.5) \\
\end{array}$ & $\begin{array}{c}3.2 \\
(0.2) \\
\end{array}$ & $\begin{array}{c}9.3 \\
(0.6) \\
\end{array}$ & $\begin{array}{r}14.5 \\
(0.6) \\
\end{array}$ & $\begin{array}{c}0.7 \\
(0.6) \\
\end{array}$ & $\begin{array}{r}18.5 \\
(0.9) \\
\end{array}$ \\
\hline $81-84$ & 1585 & $\begin{array}{c}6.5 \\
(0.4)\end{array}$ & $\begin{array}{c}1.4 \\
(0.2)\end{array}$ & $\begin{array}{c}5.1 \\
(0.5)\end{array}$ & $\begin{array}{c}26.0 \\
(1.4)\end{array}$ & $\begin{array}{c}2.3 \\
(1.4)\end{array}$ & $\begin{array}{c}30.7 \\
(1.9)\end{array}$ \\
\hline $84-87$ & 2546 & $\begin{array}{c}8.6 \\
(0.5)\end{array}$ & $\begin{array}{c}2.3 \\
(0.2)\end{array}$ & $\begin{array}{c}6.3 \\
(0.6)\end{array}$ & $\begin{array}{c}22.3 \\
(1.0)\end{array}$ & $\begin{array}{c}2.1 \\
(1.1)\end{array}$ & $\begin{array}{c}27.8 \\
(1.4)\end{array}$ \\
\hline $88-91$ & 2733 & $\begin{array}{l}10.1 \\
(0.5) \\
\end{array}$ & $\begin{array}{c}2.9 \\
(0.3) \\
\end{array}$ & $\begin{array}{c}7.1 \\
(0.6) \\
\end{array}$ & $\begin{array}{r}19.3 \\
(0.8) \\
\end{array}$ & $\begin{array}{c}0.4 \\
(0.8) \\
\end{array}$ & $\begin{array}{l}25.1 \\
(1.1)\end{array}$ \\
\hline $81-86$ & 1022 & $\begin{array}{c}6.1 \\
(0.5)\end{array}$ & $\begin{array}{c}1.4 \\
(0.2)\end{array}$ & $\begin{array}{c}4.7 \\
(0.6)\end{array}$ & $\begin{array}{c}25.5 \\
(1.6)\end{array}$ & $\begin{array}{c}2.0 \\
(1.6)\end{array}$ & $\begin{array}{c}30.4 \\
(2.2)\end{array}$ \\
\hline $86-91$ & 1748 & $\begin{array}{c}8.8 \\
(0.5) \\
\end{array}$ & $\begin{array}{c}2.6 \\
(0.3) \\
\end{array}$ & $\begin{array}{c}6.2 \\
(0.7)\end{array}$ & $\begin{array}{r}22.7 \\
(1.1) \\
\end{array}$ & $\begin{array}{c}1.7 \\
(1.1)\end{array}$ & $\begin{array}{r}29.0 \\
(1.5)\end{array}$ \\
\hline $81-88$ & 726 & $\begin{array}{c}6.4 \\
(0.6)\end{array}$ & $\begin{array}{c}1.2 \\
(0.2)\end{array}$ & $\begin{array}{c}\mathbf{5 . 2} \\
(0.7)\end{array}$ & $\begin{array}{c}27.0 \\
(2.0)\end{array}$ & $\begin{array}{c}3.1 \\
(2.0)\end{array}$ & $\begin{array}{c}31.0 \\
(2.7)\end{array}$ \\
\hline $84-91$ & 1074 & $\begin{array}{c}8.1 \\
(0.6) \\
\end{array}$ & $\begin{array}{c}2.3 \\
(0.3)\end{array}$ & $\begin{array}{c}5.8 \\
(0.8)\end{array}$ & $\begin{array}{r}26.7 \\
(1.6)\end{array}$ & $\begin{array}{c}3.4 \\
(1.6)\end{array}$ & $\begin{array}{c}33.1 \\
(2.1)\end{array}$ \\
\hline 82-91 & 546 & $\begin{array}{c}6.8 \\
(0.7)\end{array}$ & $\begin{array}{c}1.7 \\
(0.3)\end{array}$ & $\begin{array}{c}5.1 \\
(0.9)\end{array}$ & $\begin{array}{r}31.5 \\
(2.5)\end{array}$ & $\begin{array}{c}5.3 \\
(2.8) \\
\end{array}$ & $\begin{array}{c}37.4 \\
(3.4)\end{array}$ \\
\hline
\end{tabular}

Notes:

1. The wage measure is the hourly wage earned on the main job last week, deflated by the implicit price deflator for personal consumption expenditure.

2. The sample used for each measure consists of all civilian individuals neither in school nor self-employed with valid non-zero wages for the time periods relevant for that particular measure.

3. Inequality is measured using the generalized entropy measure with the inequality aversion parameter set to 2 .

4. All coefficients and standard errors are multiplied by 100 . 
TABLE V: Inequality and Mobility for Wages Samples Include Zeros, $c=2$

\begin{tabular}{|c|c|c|c|c|c|c|}
\hline \multirow[b]{2}{*}{ Year } & \multicolumn{3}{|c|}{ Maximum Sample } & \multicolumn{3}{|c|}{ Consistent Sample } \\
\hline & $N$ & $\begin{array}{c}\text { Inequality } \\
\text { Total }\end{array}$ & $\begin{array}{c}\text { Mobility } \\
\text { Total }\end{array}$ & $N$ & $\begin{array}{c}\text { Inequality } \\
\text { Total }\end{array}$ & $\begin{array}{c}\text { Mobility } \\
\text { Total }\end{array}$ \\
\hline 1981 & 6322 & $\begin{array}{c}39.6 \\
(1.8)\end{array}$ & & 2013 & $\begin{array}{c}39.0 \\
(3.0)\end{array}$ & \\
\hline 1983 & 8246 & $\begin{array}{c}43.0 \\
(1.7)\end{array}$ & & 2013 & $\begin{array}{c}39.5 \\
(2.9)\end{array}$ & \\
\hline 1985 & 8388 & $\begin{array}{c}33.7 \\
(1.2)\end{array}$ & & 2013 & $\begin{array}{c}35.1 \\
(2.6)\end{array}$ & \\
\hline 1987 & 8649 & $\begin{array}{c}33.6 \\
(1.2)\end{array}$ & & 2013 & $\begin{array}{c}33.0 \\
(2.4)\end{array}$ & \\
\hline 1989 & 8901 & $\begin{array}{c}38.4 \\
(1.3)\end{array}$ & & 2013 & $\begin{array}{c}43.9 \\
(3.3)\end{array}$ & \\
\hline 1991 & 7575 & $\begin{array}{l}45.2 \\
(1.7) \\
\end{array}$ & & 2013 & $\begin{array}{r}38.2 \\
(2.7) \\
\end{array}$ & \\
\hline $81-82$ & 5485 & $\begin{array}{c}32.4 \\
(1.5)\end{array}$ & $\begin{array}{c}20.9 \\
(0.8)\end{array}$ & 2013 & $\begin{array}{c}31.9 \\
(2.3)\end{array}$ & $\begin{array}{l}17.7 \\
(1.1)\end{array}$ \\
\hline $84-85$ & 7156 & $\begin{array}{c}29.6 \\
(1.1)\end{array}$ & $\begin{array}{c}15.7 \\
(0.6)\end{array}$ & 2013 & $\begin{array}{c}30.1 \\
(2.1)\end{array}$ & $\begin{array}{c}12.4 \\
(0.9)\end{array}$ \\
\hline $87-88$ & 7634 & $\begin{array}{c}28.1 \\
(1.0)\end{array}$ & $\begin{array}{l}17.2 \\
(0.6)\end{array}$ & 2013 & $\begin{array}{r}27.9 \\
(2.0)\end{array}$ & $\begin{array}{l}14.3 \\
(0.9)\end{array}$ \\
\hline $90-91$ & 6819 & $\begin{array}{l}31.6 \\
(1.2) \\
\end{array}$ & $\begin{array}{c}19.6 \\
(0.6) \\
\end{array}$ & 2013 & $\begin{array}{c}30.6 \\
(2.1) \\
\end{array}$ & $\begin{array}{l}15.9 \\
(1.0)\end{array}$ \\
\hline $81-84$ & 4500 & $\begin{array}{c}27.1 \\
(1.3)\end{array}$ & $\begin{array}{c}31.7 \\
(1.0)\end{array}$ & 2013 & $\begin{array}{c}25.9 \\
(1.8)\end{array}$ & $\begin{array}{c}31.0 \\
(1.3)\end{array}$ \\
\hline $84-87$ & 5833 & $\begin{array}{l}25.6 \\
(1.1)\end{array}$ & $\begin{array}{l}27.5 \\
(0.8)\end{array}$ & 2013 & $\begin{array}{l}26.0 \\
(1.8)\end{array}$ & $\begin{array}{l}24.3 \\
(1.2)\end{array}$ \\
\hline 88-91 & 5719 & $\begin{array}{l}25.5 \\
(1.0) \\
\end{array}$ & $\begin{array}{r}27.7 \\
(0.7) \\
\end{array}$ & 2013 & $\begin{array}{r}27.2 \\
(1.9) \\
\end{array}$ & $\begin{array}{l}26.8 \\
(1.2) \\
\end{array}$ \\
\hline $81-86$ & 3583 & $\begin{array}{l}24.7 \\
(1.3)\end{array}$ & $\begin{array}{l}34.8 \\
(1.1)\end{array}$ & 2013 & $\begin{array}{c}24.5 \\
(1.7)\end{array}$ & $\begin{array}{r}33.4 \\
(1.3)\end{array}$ \\
\hline $86-91$ & 4572 & $\begin{array}{r}23.2 \\
(1.0) \\
\end{array}$ & $\begin{array}{l}31.5 \\
(0.8)\end{array}$ & 2013 & $\begin{array}{r}25.3 \\
(1.7) \\
\end{array}$ & $\begin{array}{r}30.3 \\
(1.3) \\
\end{array}$ \\
\hline $81-88$ & 2993 & $\begin{array}{l}23.2 \\
(1.3)\end{array}$ & $\begin{array}{l}37.0 \\
(1.2)\end{array}$ & 2013 & $\begin{array}{c}22.8 \\
(1.6)\end{array}$ & $\begin{array}{l}35.7 \\
(1.4)\end{array}$ \\
\hline $84-91$ & 3634 & $\begin{array}{c}23.1 \\
(1.2) \\
\end{array}$ & $\begin{array}{r}34.6 \\
(1.0) \\
\end{array}$ & 2013 & $\begin{array}{r}23.9 \\
(1.6) \\
\end{array}$ & $\begin{array}{r}33.4 \\
(1.3) \\
\end{array}$ \\
\hline $82-91$ & 2546 & $\begin{array}{c}22.7 \\
(1.4)\end{array}$ & $\begin{array}{c}38.1 \\
(1.2)\end{array}$ & 2013 & $\begin{array}{l}22.7 \\
(1.5)\end{array}$ & $\begin{array}{l}37.6 \\
(1.4)\end{array}$ \\
\hline
\end{tabular}

Notes:

1. The wage measure is the hourly wage earned on the main job last week, deflated by the implicit price deflator for personal consumption expenditure.

2. The maximum and consistent samples are described in Tables I and II, respectively.

3. Inequality is measured using the generalized entropy measure with the inequality aversion parameter set to 2 .

4. All coefficients and standard errors are multiplied by 100 . 
TABLE VI: Inequality and Mobility for Earnings Maximum Sample, $c=2$

\begin{tabular}{|c|c|c|c|c|c|c|c|}
\hline \multirow[t]{2}{*}{ Year } & \multirow[t]{2}{*}{$N$} & \multicolumn{3}{|c|}{ Inequality } & \multicolumn{3}{|c|}{ Mobility } \\
\hline & & Total & Between & Within & Total & Between & Within \\
\hline 1980 & 3290 & $\begin{array}{c}22.2 \\
(1.2)\end{array}$ & $\begin{array}{c}9.7 \\
(1.4)\end{array}$ & $\begin{array}{c}12.5 \\
(2.4)\end{array}$ & & & \\
\hline 1982 & 4971 & $\begin{array}{l}25.3 \\
(1.2)\end{array}$ & $\begin{array}{l}10.0 \\
(1.2)\end{array}$ & $\begin{array}{c}15.3 \\
(2.1)\end{array}$ & & & \\
\hline 1984 & 5926 & $\begin{array}{c}22.4 \\
(0.9)\end{array}$ & $\begin{array}{c}9.2 \\
(0.9)\end{array}$ & $\begin{array}{l}13.2 \\
(1.7)\end{array}$ & & & \\
\hline 1986 & 6171 & $\begin{array}{l}21.9 \\
(0.8)\end{array}$ & $\begin{array}{c}6.6 \\
(0.6)\end{array}$ & $\begin{array}{l}15.3 \\
(1.3)\end{array}$ & & & \\
\hline 1988 & 6487 & $\begin{array}{c}19.8 \\
(0.7)\end{array}$ & $\begin{array}{c}6.2 \\
(0.6)\end{array}$ & $\begin{array}{c}13.5 \\
(1.1)\end{array}$ & & & \\
\hline 1990 & 5769 & $\begin{array}{r}27.3 \\
(1.0) \\
\end{array}$ & $\begin{array}{c}7.3 \\
(0.7) \\
\end{array}$ & $\begin{array}{c}20.0 \\
(1.5)\end{array}$ & & & \\
\hline $80-81$ & 2425 & $\begin{array}{c}16.0 \\
(0.9)\end{array}$ & $\begin{array}{c}5.9 \\
(0.8)\end{array}$ & $\begin{array}{c}10.1 \\
(1.5)\end{array}$ & $\begin{array}{c}12.6 \\
(0.8)\end{array}$ & $\begin{array}{c}-0.5 \\
(3.3)\end{array}$ & $\begin{array}{c}18.7 \\
(3.5)\end{array}$ \\
\hline 83-84 & 4134 & $\begin{array}{l}17.3 \\
(0.8)\end{array}$ & $\begin{array}{c}6.8 \\
(0.7)\end{array}$ & $\begin{array}{c}10.5 \\
(1.3)\end{array}$ & $\begin{array}{c}12.0 \\
(0.6)\end{array}$ & $\begin{array}{l}-4.5 \\
(2.5)\end{array}$ & $\begin{array}{c}20.1 \\
(2.5)\end{array}$ \\
\hline $86-87$ & 4884 & $\begin{array}{c}17.1 \\
(0.7)\end{array}$ & $\begin{array}{c}5.9 \\
(0.5)\end{array}$ & $\begin{array}{l}11.3 \\
(1.0)\end{array}$ & $\begin{array}{c}9.5 \\
(0.4)\end{array}$ & $\begin{array}{c}-3.8 \\
(1.6)\end{array}$ & $\begin{array}{l}15.1 \\
(1.7)\end{array}$ \\
\hline $89-90$ & 4641 & $\begin{array}{r}21.0 \\
(0.9) \\
\end{array}$ & $\begin{array}{c}5.9 \\
(0.5) \\
\end{array}$ & $\begin{array}{l}15.0 \\
(1.1)\end{array}$ & $\begin{array}{c}7.4 \\
(0.3) \\
\end{array}$ & $\begin{array}{l}-3.0 \\
(1.4)\end{array}$ & $\begin{array}{c}10.9 \\
(1.5)\end{array}$ \\
\hline $80-83$ & 1614 & $\begin{array}{c}12.0 \\
(0.8)\end{array}$ & $\begin{array}{c}3.5 \\
(0.5)\end{array}$ & $\begin{array}{c}8.6 \\
(1.2)\end{array}$ & $\begin{array}{c}24.6 \\
(1.3)\end{array}$ & $\begin{array}{c}-5.5 \\
(4.9)\end{array}$ & $\begin{array}{c}32.4 \\
(5.4)\end{array}$ \\
\hline $83-86$ & 2868 & $\begin{array}{c}13.0 \\
(0.7)\end{array}$ & $\begin{array}{c}4.7 \\
(0.5)\end{array}$ & $\begin{array}{c}8.3 \\
(1.0)\end{array}$ & $\begin{array}{c}19.2 \\
(0.9)\end{array}$ & $\begin{array}{c}-5.2 \\
(3.3)\end{array}$ & $\begin{array}{l}28.7 \\
(3.4)\end{array}$ \\
\hline $87-90$ & 3290 & $\begin{array}{r}15.3 \\
(0.7) \\
\end{array}$ & $\begin{array}{c}5.0 \\
(0.4) \\
\end{array}$ & $\begin{array}{c}10.3 \\
(1.0)\end{array}$ & $\begin{array}{r}14.6 \\
(0.6) \\
\end{array}$ & $\begin{array}{c}-3.7 \\
(1.7)\end{array}$ & $\begin{array}{r}21.3 \\
(1.9) \\
\end{array}$ \\
\hline $80-85$ & 1176 & $\begin{array}{c}10.6 \\
(0.8)\end{array}$ & $\begin{array}{c}3.1 \\
(0.5)\end{array}$ & $\begin{array}{c}7.5 \\
(1.1)\end{array}$ & $\begin{array}{c}27.8 \\
(1.6)\end{array}$ & $\begin{array}{c}-3.2 \\
(4.5)\end{array}$ & $\begin{array}{c}35.8 \\
(5.2)\end{array}$ \\
\hline $85-90$ & 2258 & $\begin{array}{l}13.1 \\
(0.7) \\
\end{array}$ & $\begin{array}{c}4.4 \\
(0.4) \\
\end{array}$ & $\begin{array}{c}8.7 \\
(1.0)\end{array}$ & $\begin{array}{l}19.7 \\
(0.9)\end{array}$ & $\begin{array}{c}-3.2 \\
(2.2)\end{array}$ & $\begin{array}{c}27.8 \\
(2.5)\end{array}$ \\
\hline $80-87$ & 899 & $\begin{array}{c}9.1 \\
(0.8)\end{array}$ & $\begin{array}{c}2.7 \\
(0.5)\end{array}$ & $\begin{array}{c}6.4 \\
(1.1)\end{array}$ & $\begin{array}{c}28.7 \\
(1.9)\end{array}$ & $\begin{array}{c}-4.3 \\
(4.9)\end{array}$ & $\begin{array}{c}37.2 \\
(5.6)\end{array}$ \\
\hline $83-90$ & 1474 & $\begin{array}{l}10.8 \\
(0.7) \\
\end{array}$ & $\begin{array}{c}3.6 \\
(0.4) \\
\end{array}$ & $\begin{array}{c}7.2 \\
(1.0)\end{array}$ & $\begin{array}{r}24.5 \\
(1.3)\end{array}$ & $\begin{array}{l}-1.5 \\
(3.1)\end{array}$ & $\begin{array}{c}33.1 \\
(3.5)\end{array}$ \\
\hline $81-90$ & 801 & $\begin{array}{c}9.0 \\
(0.8)\end{array}$ & $\begin{array}{c}2.7 \\
(0.4)\end{array}$ & $\begin{array}{c}6.3 \\
(1.1)\end{array}$ & $\begin{array}{c}27.5 \\
(1.9)\end{array}$ & $\begin{array}{c}-5.0 \\
(4.6)\end{array}$ & $\begin{array}{c}36.1 \\
(5.3)\end{array}$ \\
\hline
\end{tabular}

Notes:

1. Earnings are computed as annual earnings deflated by the implicit price deflator for personal consumption expenditure.

2. The sample used for each measure consists of all civilian individuals with valid non-zero wages for the time periods relevant for that particular measure.

3. Inequality is measured using the generalized entropy measure with the inequality aversion parameter set to 2 .

4. All coefficients and standard errors are multiplied by 100 . 
TABLE VII: Inequality and Mobility for Earnings Maximum Sample Including Zeros, $c=2$

\begin{tabular}{|c|c|c|c|c|c|c|}
\hline \multirow[b]{2}{*}{ Year } & \multirow[b]{2}{*}{$N$} & \multicolumn{2}{|c|}{ Maximum Sample } & \multicolumn{3}{|c|}{ Consistent Sample } \\
\hline & & $\begin{array}{c}\text { Inequality } \\
\text { Total }\end{array}$ & $\begin{array}{c}\text { Mobility } \\
\text { Total }\end{array}$ & $N$ & $\begin{array}{c}\text { Inequality } \\
\text { Total }\end{array}$ & $\begin{array}{c}\text { Mobility } \\
\text { Total }\end{array}$ \\
\hline 1980 & 4148 & $\begin{array}{l}35.3 \\
(1.9)\end{array}$ & & 936 & $\begin{array}{l}25.5 \\
(2.6)\end{array}$ & \\
\hline 1982 & 6296 & $\begin{array}{c}39.8 \\
(1.8)\end{array}$ & & 936 & $\begin{array}{c}27.5 \\
(2.9)\end{array}$ & \\
\hline 1984 & 7239 & $\begin{array}{l}34.0 \\
(1.3)\end{array}$ & & 936 & $\begin{array}{l}26.6 \\
(2.7)\end{array}$ & \\
\hline 1986 & 7540 & $\begin{array}{c}33.8 \\
(1.3)\end{array}$ & & 936 & $\begin{array}{c}26.3 \\
(2.7)\end{array}$ & \\
\hline 1988 & 7860 & $\begin{array}{c}31.4 \\
(1.1)\end{array}$ & & 936 & $\begin{array}{c}28.1 \\
(2.8)\end{array}$ & \\
\hline 1990 & 6979 & $\begin{array}{l}40.5 \\
(1.5) \\
\end{array}$ & & 936 & $\begin{array}{r}29.9 \\
(2.9) \\
\end{array}$ & \\
\hline $80-81$ & 3300 & $\begin{array}{c}30.0 \\
(1.7)\end{array}$ & $\begin{array}{c}9.7 \\
(0.5)\end{array}$ & 936 & $\begin{array}{c}23.6 \\
(2.4)\end{array}$ & $\begin{array}{c}8.9 \\
(0.9)\end{array}$ \\
\hline $83-84$ & 5589 & $\begin{array}{c}31.8 \\
(1.4)\end{array}$ & $\begin{array}{c}9.1 \\
(0.4)\end{array}$ & 936 & $\begin{array}{l}24.9 \\
(2.5)\end{array}$ & $\begin{array}{c}7.4 \\
(0.8)\end{array}$ \\
\hline $86-87$ & 6265 & $\begin{array}{c}29.5 \\
(1.2)\end{array}$ & $\begin{array}{c}7.6 \\
(0.3)\end{array}$ & 936 & $\begin{array}{c}24.9 \\
(2.5)\end{array}$ & $\begin{array}{c}6.5 \\
(0.7)\end{array}$ \\
\hline $89-90$ & 5892 & $\begin{array}{l}34.5 \\
(1.4) \\
\end{array}$ & $\begin{array}{r}6.2 \\
(0.3) \\
\end{array}$ & 936 & $\begin{array}{r}27.3 \\
(2.7) \\
\end{array}$ & $\begin{array}{c}4.6 \\
(0.5) \\
\end{array}$ \\
\hline $80-83$ & 2462 & $\begin{array}{c}27.5 \\
(1.8)\end{array}$ & $\begin{array}{c}17.8 \\
(0.9)\end{array}$ & 936 & $\begin{array}{r}22.3 \\
(2.2)\end{array}$ & $\begin{array}{c}16.7 \\
(1.3)\end{array}$ \\
\hline $83-86$ & 4139 & $\begin{array}{c}26.9 \\
(1.3)\end{array}$ & $\begin{array}{l}14.9 \\
(0.6)\end{array}$ & 936 & $\begin{array}{l}23.2 \\
(2.3)\end{array}$ & $\begin{array}{c}14.5 \\
(1.2)\end{array}$ \\
\hline $87-90$ & 4381 & $\begin{array}{l}28.1 \\
(1.3) \\
\end{array}$ & $\begin{array}{l}12.0 \\
(0.5) \\
\end{array}$ & 936 & $\begin{array}{r}25.5 \\
(2.5) \\
\end{array}$ & $\begin{array}{c}9.3 \\
(0.8) \\
\end{array}$ \\
\hline $80-85$ & 1910 & $\begin{array}{c}26.3 \\
(1.9)\end{array}$ & $\begin{array}{l}19.7 \\
(1.0)\end{array}$ & 936 & $\begin{array}{l}21.8 \\
(2.1)\end{array}$ & $\begin{array}{c}19.2 \\
(1.4)\end{array}$ \\
\hline $85-90$ & 3163 & $\begin{array}{l}25.6 \\
(1.3) \\
\end{array}$ & $\begin{array}{r}16.4 \\
(0.7) \\
\end{array}$ & 936 & $\begin{array}{l}23.7 \\
(2.3) \\
\end{array}$ & $\begin{array}{l}14.7 \\
(1.1) \\
\end{array}$ \\
\hline $80-87$ & 1469 & $\begin{array}{l}23.0 \\
(1.9)\end{array}$ & $\begin{array}{l}22.0 \\
(1.3)\end{array}$ & 936 & $\begin{array}{l}21.0 \\
(2.1)\end{array}$ & $\begin{array}{l}22.0 \\
(1.5)\end{array}$ \\
\hline $83-90$ & 2229 & $\begin{array}{l}23.4 \\
(1.5) \\
\end{array}$ & $\begin{array}{l}20.6 \\
(1.0) \\
\end{array}$ & 936 & $\begin{array}{l}22.4 \\
(2.2) \\
\end{array}$ & $\begin{array}{r}18.9 \\
(1.4) \\
\end{array}$ \\
\hline $81-90$ & 1296 & $\begin{array}{c}21.8 \\
(1.8)\end{array}$ & $\begin{array}{c}24.1 \\
(1.4)\end{array}$ & 936 & $\begin{array}{c}21.4 \\
(2.1)\end{array}$ & $\begin{array}{c}22.3 \\
(1.5)\end{array}$ \\
\hline
\end{tabular}

Notes:

1. Earnings are computed as annual earnings deflated by the implicit price deflator for personal consumption expenditure.

2. The maximum and consistent samples are described in Table I and II, respectively. 3. Inequality is measured using the generalized entropy measure with the inequality aversion parameter set to 2 .

4. All coefficients and standard errors are multiplied by 100 . 
TABLE VIII: Conditional Staying Probabilities of Earnings, by Quintiles

\begin{tabular}{|c|c|c|c|c|c|c|c|c|c|c|c|c|}
\hline & $\mathbf{0}^{\mathbf{a}}$ & $\mathbf{1}^{\mathbf{b}}$ & $2^{c}$ & $\mathbf{3}^{\mathbf{d}}$ & $4^{e}$ & $\mathbf{5}^{\mathbf{f}}$ & $\mathbf{0}^{\mathbf{a}}$ & $1^{b}$ & $2^{c}$ & $\mathbf{3}^{\mathbf{d}}$ & $4^{e}$ & $\mathbf{5}^{\mathrm{f}}$ \\
\hline \multicolumn{13}{|c|}{ Elementary School Graduates (8 Years of Education): } \\
\hline & \multicolumn{6}{|c|}{100 Weeks of Experience } & \multicolumn{6}{|c|}{300 Weeks of Experience } \\
\hline 1980 & $\begin{array}{c}.74 \\
(.01)\end{array}$ & $\begin{array}{c}.31 \\
(.16)\end{array}$ & $\begin{array}{c}.32 \\
(.06)\end{array}$ & $\begin{array}{c}.33 \\
(.03)\end{array}$ & $\begin{array}{c}.46 \\
(.03)\end{array}$ & $\begin{array}{c}.66 \\
(.03)\end{array}$ & $\begin{array}{c}.69 \\
(.06)\end{array}$ & $\begin{array}{c}.31 \\
(.17)\end{array}$ & $\begin{array}{c}.32 \\
(.07)\end{array}$ & $\begin{array}{c}.36 \\
(.05)\end{array}$ & $\begin{array}{c}.49 \\
(.06)\end{array}$ & $\begin{array}{c}.68 \\
(.05)\end{array}$ \\
\hline 1984 & $\begin{array}{c}.72 \\
(.01)\end{array}$ & $\begin{array}{c}.42 \\
(.05)\end{array}$ & $\begin{array}{c}.37 \\
(.06)\end{array}$ & $\begin{array}{c}.51 \\
(.07)\end{array}$ & $\begin{array}{c}.61 \\
(.02)\end{array}$ & $\begin{array}{c}.63 \\
(.01)\end{array}$ & $\begin{array}{c}.72 \\
(.02)\end{array}$ & $\begin{array}{c}.43 \\
(.05)\end{array}$ & $\begin{array}{c}.36 \\
(.06)\end{array}$ & $\begin{array}{c}.51 \\
(.08)\end{array}$ & $\begin{array}{c}.60 \\
(.02)\end{array}$ & $\begin{array}{c}.69 \\
(.01)\end{array}$ \\
\hline 1987 & $\begin{array}{c}.69 \\
(.01)\end{array}$ & $\begin{array}{c}.47 \\
(.05)\end{array}$ & $\begin{array}{c}.52 \\
(.02)\end{array}$ & $\begin{array}{c}.41 \\
(.07)\end{array}$ & $\begin{array}{c}.42 \\
(.04)\end{array}$ & $\begin{array}{c}.41 \\
(.05)\end{array}$ & $\begin{array}{c}.72 \\
(.01)\end{array}$ & $\begin{array}{c}.50 \\
(.03)\end{array}$ & $\begin{array}{c}.57 \\
(.02)\end{array}$ & $\begin{array}{c}.44 \\
(.06)\end{array}$ & $\begin{array}{c}.41 \\
(.02)\end{array}$ & $\begin{array}{c}.50 \\
(.04)\end{array}$ \\
\hline 1990 & $\begin{array}{c}.75 \\
(.02)\end{array}$ & $\begin{array}{c}.58 \\
(.08)\end{array}$ & $\begin{array}{l}.55 \\
(.03)\end{array}$ & $\begin{array}{c}.50 \\
(.08)\end{array}$ & $\begin{array}{c}.67 \\
(.08)\end{array}$ & $\begin{array}{c}.61 \\
(.05)\end{array}$ & $\begin{array}{c}.72 \\
(.02)\end{array}$ & $\begin{array}{c}.57 \\
(.04)\end{array}$ & $\begin{array}{c}.58 \\
(.02)\end{array}$ & $\begin{array}{c}.51 \\
(.07)\end{array}$ & $\begin{array}{c}.71 \\
(.03)\end{array}$ & $\begin{array}{c}.59 \\
(.02)\end{array}$ \\
\hline & \multicolumn{6}{|c|}{500 Weeks of Experience } & \multicolumn{6}{|c|}{700 Weeks of Experience } \\
\hline 1980 & $\begin{array}{c}.60 \\
(.24)\end{array}$ & $\begin{array}{c}.32 \\
(.19)\end{array}$ & $\begin{array}{c}.32 \\
(.10)\end{array}$ & $\begin{array}{c}.38 \\
(.13)\end{array}$ & $\begin{array}{c}.51 \\
(.24)\end{array}$ & $\begin{array}{c}.77 \\
(.18)\end{array}$ & $\begin{array}{c}.46 \\
(.26)\end{array}$ & $\begin{array}{c}.33 \\
(.27)\end{array}$ & $\begin{array}{c}.31 \\
(.17)\end{array}$ & $\begin{array}{c}.42 \\
(.28)\end{array}$ & $\begin{array}{c}.52 \\
(.28)\end{array}$ & $\begin{array}{c}.92 \\
(.29)\end{array}$ \\
\hline 1984 & $\begin{array}{c}.65 \\
(.08)\end{array}$ & $\begin{array}{l}.41 \\
(.07)\end{array}$ & $\begin{array}{c}.35 \\
(.07)\end{array}$ & $\begin{array}{c}.50 \\
(.10)\end{array}$ & $\begin{array}{c}.59 \\
(.04)\end{array}$ & $\begin{array}{c}.73 \\
(.05)\end{array}$ & $\begin{array}{c}.41 \\
(.26)\end{array}$ & $\begin{array}{c}.41 \\
(.11)\end{array}$ & $\begin{array}{c}.36 \\
(.11)\end{array}$ & $\begin{array}{c}.48 \\
(.18)\end{array}$ & $\begin{array}{c}.61 \\
(.13)\end{array}$ & $\begin{array}{r}.63 \\
(.28)\end{array}$ \\
\hline 1987 & $\begin{array}{c}.77 \\
(.04)\end{array}$ & $\begin{array}{c}.51 \\
(.05)\end{array}$ & $\begin{array}{c}.59 \\
(.03)\end{array}$ & $\begin{array}{l}.44 \\
(.07)\end{array}$ & $\begin{array}{c}.69 \\
(.03)\end{array}$ & $\begin{array}{c}.49 \\
(.05)\end{array}$ & $\begin{array}{c}.72 \\
(.10)\end{array}$ & $\begin{array}{c}.53 \\
(.11)\end{array}$ & $\begin{array}{c}.55 \\
(.08)\end{array}$ & $\begin{array}{c}.42 \\
(.13)\end{array}$ & $\begin{array}{c}.75 \\
(.13)\end{array}$ & $\begin{array}{c}.54 \\
(.09)\end{array}$ \\
\hline 1990 & $\begin{array}{c}.66 \\
(.03)\end{array}$ & $\begin{array}{c}.58 \\
(.04)\end{array}$ & $\begin{array}{c}.59 \\
(.02)\end{array}$ & $\begin{array}{c}.53 \\
(.07)\end{array}$ & $\begin{array}{c}.72 \\
(.03)\end{array}$ & $\begin{array}{c}.61 \\
(.02)\end{array}$ & $\begin{array}{c}.61 \\
(.05)\end{array}$ & $\begin{array}{c}.62 \\
(.06)\end{array}$ & $\begin{array}{c}.58 \\
(.04)\end{array}$ & $\begin{array}{c}.54 \\
(.08)\end{array}$ & $\begin{array}{c}.71 \\
(.04)\end{array}$ & $\begin{array}{c}.68 \\
(.03)\end{array}$ \\
\hline \multicolumn{13}{|c|}{ High School Graduates (12 Years of Education): } \\
\hline & \multicolumn{6}{|c|}{100 Weeks of Experience } & \multicolumn{6}{|c|}{300 Weeks of Experience } \\
\hline 1980 & $\begin{array}{c}.63 \\
(.01)\end{array}$ & $\begin{array}{c}.34 \\
(.16)\end{array}$ & $\begin{array}{c}.31 \\
(.06)\end{array}$ & $\begin{array}{c}.34 \\
(.02)\end{array}$ & $\begin{array}{c}.52 \\
(.01)\end{array}$ & $\begin{array}{c}.54 \\
(.00)\end{array}$ & $\begin{array}{c}.60 \\
(.04)\end{array}$ & $\begin{array}{c}.34 \\
(.16)\end{array}$ & $\begin{array}{c}.31 \\
(.07)\end{array}$ & $\begin{array}{c}.35 \\
(.04)\end{array}$ & $\begin{array}{c}.55 \\
(.03)\end{array}$ & $\begin{array}{c}.70 \\
(.03)\end{array}$ \\
\hline 1984 & $\begin{array}{c}.69 \\
(.01)\end{array}$ & $\begin{array}{c}.42 \\
(.04)\end{array}$ & $\begin{array}{c}.37 \\
(.05)\end{array}$ & $\begin{array}{c}.51 \\
(.07)\end{array}$ & $\begin{array}{c}.61 \\
(.02)\end{array}$ & $\begin{array}{c}.62 \\
(.00)\end{array}$ & $\begin{array}{c}.71 \\
(.01)\end{array}$ & $\begin{array}{c}.42 \\
(.05)\end{array}$ & $\begin{array}{c}.37 \\
(.06)\end{array}$ & $\begin{array}{c}.51 \\
(.07)\end{array}$ & $\begin{array}{c}.61 \\
(.02)\end{array}$ & $\begin{array}{c}.66 \\
(.00)\end{array}$ \\
\hline 1987 & $\begin{array}{c}.68 \\
(.00)\end{array}$ & $\begin{array}{c}.48 \\
(.03)\end{array}$ & $\begin{array}{c}.52 \\
(.01)\end{array}$ & $\begin{array}{c}.40 \\
(.05)\end{array}$ & $\begin{array}{c}.64 \\
(.01)\end{array}$ & $\begin{array}{c}.57 \\
(.02)\end{array}$ & $\begin{array}{c}.72 \\
(.00)\end{array}$ & $\begin{array}{c}.49 \\
(.02)\end{array}$ & $\begin{array}{c}.55 \\
(.01)\end{array}$ & $\begin{array}{c}.44 \\
(.05)\end{array}$ & $\begin{array}{c}.61 \\
(.00)\end{array}$ & $\begin{array}{c}.52 \\
(.01)\end{array}$ \\
\hline 1990 & $\begin{array}{c}.75 \\
(.02)\end{array}$ & $\begin{array}{c}.57 \\
(.05)\end{array}$ & $\begin{array}{c}.55 \\
(.03)\end{array}$ & $\begin{array}{c}.50 \\
(.07)\end{array}$ & $\begin{array}{c}.75 \\
(.04)\end{array}$ & $\begin{array}{c}.66 \\
(.03)\end{array}$ & $\begin{array}{c}.72 \\
(.01)\end{array}$ & $\begin{array}{c}.57 \\
(.02)\end{array}$ & $\begin{array}{l}.58 \\
(.02)\end{array}$ & $\begin{array}{c}.53 \\
(.06)\end{array}$ & $\begin{array}{c}.75 \\
(.02)\end{array}$ & $\begin{array}{c}.63 \\
(.01)\end{array}$ \\
\hline & \multicolumn{6}{|c|}{500 Weeks of Experience } & \multicolumn{6}{|c|}{700 Weeks of Experience } \\
\hline 1980 & $\begin{array}{c}.51 \\
(.22)\end{array}$ & $\begin{array}{c}.34 \\
(.19)\end{array}$ & $\begin{array}{c}.31 \\
(.09)\end{array}$ & $\begin{array}{c}.37 \\
(.10)\end{array}$ & $\begin{array}{c}.55 \\
(.14)\end{array}$ & $\begin{array}{c}.73 \\
(.13)\end{array}$ & $\begin{array}{c}.40 \\
(.26)\end{array}$ & $\begin{array}{c}.33 \\
(.26)\end{array}$ & $\begin{array}{c}.30 \\
(.16)\end{array}$ & $\begin{array}{c}.40 \\
(.28)\end{array}$ & $\begin{array}{c}.56 \\
(.28)\end{array}$ & $\begin{array}{c}.92 \\
(.28)\end{array}$ \\
\hline 1984 & $\begin{array}{c}.66 \\
(.04)\end{array}$ & $\begin{array}{c}.41 \\
(.06)\end{array}$ & $\begin{array}{l}.36 \\
(.06)\end{array}$ & $\begin{array}{c}.53 \\
(.08)\end{array}$ & $\begin{array}{c}.61 \\
(.03)\end{array}$ & $\begin{array}{c}.73 \\
(.01)\end{array}$ & $\begin{array}{c}.46 \\
(.24)\end{array}$ & $\begin{array}{c}.41 \\
(.10)\end{array}$ & $\begin{array}{c}.36 \\
(.10)\end{array}$ & $\begin{array}{l}.50 \\
(.15)\end{array}$ & $\begin{array}{c}.61 \\
(.08)\end{array}$ & $\begin{array}{c}.76 \\
(.26)\end{array}$ \\
\hline 1987 & $\begin{array}{c}.63 \\
(.02)\end{array}$ & $\begin{array}{c}.51 \\
(.03)\end{array}$ & $\begin{array}{c}.56 \\
(.02)\end{array}$ & $\begin{array}{c}.44 \\
(.05)\end{array}$ & $\begin{array}{c}.70 \\
(.01)\end{array}$ & $\begin{array}{c}.64 \\
(.02)\end{array}$ & $\begin{array}{c}.65 \\
(.07)\end{array}$ & $\begin{array}{c}.52 \\
(.08)\end{array}$ & $\begin{array}{c}.55 \\
(.05)\end{array}$ & $\begin{array}{c}.43 \\
(.08)\end{array}$ & $\begin{array}{c}.77 \\
(.05)\end{array}$ & $\begin{array}{c}.73 \\
(.05)\end{array}$ \\
\hline 1990 & $\begin{array}{c}.68 \\
(.02)\end{array}$ & $\begin{array}{l}.59 \\
(.02)\end{array}$ & $\begin{array}{c}.59 \\
(.02)\end{array}$ & $\begin{array}{c}.55 \\
(.06)\end{array}$ & $\begin{array}{c}.74 \\
(.01)\end{array}$ & $\begin{array}{c}.66 \\
(.01)\end{array}$ & $\begin{array}{c}.64 \\
(.03)\end{array}$ & $\begin{array}{c}.63 \\
(.04)\end{array}$ & $\begin{array}{c}.58 \\
(.02)\end{array}$ & $\begin{array}{c}.56 \\
(.07)\end{array}$ & $\begin{array}{l}.73 \\
(.02)\end{array}$ & $\begin{array}{c}.73 \\
(.02)\end{array}$ \\
\hline
\end{tabular}


TABLE VIII (Continued)

\begin{tabular}{|c|c|c|c|c|c|c|c|c|c|c|c|c|}
\hline & $\mathbf{0}^{\mathbf{a}}$ & $1^{\mathbf{b}}$ & $2^{\mathbf{c}}$ & $\mathbf{3}^{\mathrm{d}}$ & $4^{e}$ & $5^{f}$ & $\mathbf{0}^{\mathbf{a}}$ & $\mathbf{1}^{\mathbf{b}}$ & $2^{\mathrm{c}}$ & $\mathbf{3}^{\mathrm{d}}$ & $4^{e}$ & $5^{f}$ \\
\hline \multicolumn{13}{|c|}{ College Graduates (16 Years of Education): } \\
\hline & \multicolumn{6}{|c|}{100 Weeks of Experience } & \multicolumn{6}{|c|}{300 Weeks of Experience } \\
\hline 1980 & $\begin{array}{c}.73 \\
(.03)\end{array}$ & $\begin{array}{c}.36 \\
(.17)\end{array}$ & $\begin{array}{c}.30 \\
(.07)\end{array}$ & $\begin{array}{c}.35 \\
(.04)\end{array}$ & $\begin{array}{c}.55 \\
(.03)\end{array}$ & $\begin{array}{c}1.0 \\
(.00)\end{array}$ & $\begin{array}{c}.72 \\
(.10)\end{array}$ & $\begin{array}{c}.37 \\
(.18)\end{array}$ & $\begin{array}{c}.30 \\
(.08)\end{array}$ & $\begin{array}{c}.35 \\
(.06)\end{array}$ & $\begin{array}{c}.58 \\
(.07)\end{array}$ & $\begin{array}{c}1.0 \\
(.00)\end{array}$ \\
\hline 1984 & $\begin{array}{c}.69 \\
(.02)\end{array}$ & $\begin{array}{c}.35 \\
(.05)\end{array}$ & $\begin{array}{c}.36 \\
(.06)\end{array}$ & $\begin{array}{c}.45 \\
(.07)\end{array}$ & $\begin{array}{c}.56 \\
(.02)\end{array}$ & $\begin{array}{c}.71 \\
(.01)\end{array}$ & $\begin{array}{c}.67 \\
(.03)\end{array}$ & $\begin{array}{c}.39 \\
(.05)\end{array}$ & $\begin{array}{c}.35 \\
(.06)\end{array}$ & $\begin{array}{c}.46 \\
(.08)\end{array}$ & $\begin{array}{c}.58 \\
(.02)\end{array}$ & $\begin{array}{c}.77 \\
(.01)\end{array}$ \\
\hline 1987 & $\begin{array}{c}.76 \\
(.02)\end{array}$ & $\begin{array}{c}.46 \\
(.03)\end{array}$ & $\begin{array}{c}.52 \\
(.02)\end{array}$ & $\begin{array}{c}.34 \\
(.05)\end{array}$ & $\begin{array}{c}.45 \\
(.01)\end{array}$ & $\begin{array}{c}.85 \\
(.01)\end{array}$ & $\begin{array}{c}.72 \\
(.01)\end{array}$ & $\begin{array}{l}.49 \\
(.03)\end{array}$ & $\begin{array}{c}.52 \\
(.02)\end{array}$ & $\begin{array}{c}.39 \\
(.05)\end{array}$ & $\begin{array}{c}.61 \\
(.01)\end{array}$ & $\begin{array}{c}.81 \\
(.01)\end{array}$ \\
\hline 1990 & $\begin{array}{l}.75 \\
(.03)\end{array}$ & $\begin{array}{c}.58 \\
(.04)\end{array}$ & $\begin{array}{c}.57 \\
(.03)\end{array}$ & $\begin{array}{c}.52 \\
(.07)\end{array}$ & $\begin{array}{c}.82 \\
(.03)\end{array}$ & $\begin{array}{c}.77 \\
(.02)\end{array}$ & $\begin{array}{c}.72 \\
(.02)\end{array}$ & $\begin{array}{c}.58 \\
(.03)\end{array}$ & $\begin{array}{c}.60 \\
(.02)\end{array}$ & $\begin{array}{c}.51 \\
(.07)\end{array}$ & $\begin{array}{c}.76 \\
(.02)\end{array}$ & $\begin{array}{c}.76 \\
(.01)\end{array}$ \\
\hline & \multicolumn{6}{|c|}{500 Weeks of Experience } & \multicolumn{6}{|c|}{700 Weeks of Experience } \\
\hline 1980 & $\begin{array}{c}.79 \\
(.26)\end{array}$ & $\begin{array}{c}.35 \\
(.23)\end{array}$ & $\begin{array}{c}.30 \\
(.12)\end{array}$ & $\begin{array}{c}.36 \\
(.17)\end{array}$ & $\begin{array}{c}.60 \\
(.26)\end{array}$ & $\begin{array}{c}.84 \\
(.22)\end{array}$ & $\begin{array}{c}.79 \\
(.26)\end{array}$ & $\begin{array}{c}.34 \\
(.27)\end{array}$ & $\begin{array}{c}.29 \\
(.18)\end{array}$ & $\begin{array}{c}.37 \\
(.28)\end{array}$ & $\begin{array}{c}.62 \\
(.28)\end{array}$ & $\begin{array}{c}.93 \\
(.29)\end{array}$ \\
\hline 1984 & $\begin{array}{c}.70 \\
(.07)\end{array}$ & $\begin{array}{l}.40 \\
(.07)\end{array}$ & $\begin{array}{c}.36 \\
(.07)\end{array}$ & $\begin{array}{c}.49 \\
(.10)\end{array}$ & $\begin{array}{c}.58 \\
(.04)\end{array}$ & $\begin{array}{c}.82 \\
(.04)\end{array}$ & $\begin{array}{c}.75 \\
(.24)\end{array}$ & $\begin{array}{c}.40 \\
(.12)\end{array}$ & $\begin{array}{c}.37 \\
(.11)\end{array}$ & $\begin{array}{c}.48 \\
(.17)\end{array}$ & $\begin{array}{c}.59 \\
(.10)\end{array}$ & $\begin{array}{c}.88 \\
(.28)\end{array}$ \\
\hline 1987 & $\begin{array}{c}.60 \\
(.03)\end{array}$ & $\begin{array}{c}.51 \\
(.05)\end{array}$ & $\begin{array}{c}.53 \\
(.02)\end{array}$ & $\begin{array}{c}.42 \\
(.06)\end{array}$ & $\begin{array}{c}.53 \\
(.01)\end{array}$ & $\begin{array}{c}.80 \\
(.01)\end{array}$ & $\begin{array}{c}.69 \\
(.09)\end{array}$ & $\begin{array}{c}.51 \\
(.10)\end{array}$ & $\begin{array}{c}.54 \\
(.06)\end{array}$ & $\begin{array}{c}.41 \\
(.07)\end{array}$ & $\begin{array}{c}.37 \\
(.07)\end{array}$ & $\begin{array}{c}.86 \\
(.04)\end{array}$ \\
\hline 1990 & $\begin{array}{c}.66 \\
(.02)\end{array}$ & $\begin{array}{c}.59 \\
(.03)\end{array}$ & $\begin{array}{l}.60 \\
(.02)\end{array}$ & $\begin{array}{c}.52 \\
(.07)\end{array}$ & $\begin{array}{c}.73 \\
(.02)\end{array}$ & $\begin{array}{c}.80 \\
(.01)\end{array}$ & $\begin{array}{l}.61 \\
(.04)\end{array}$ & $\begin{array}{l}.59 \\
(.05)\end{array}$ & $\begin{array}{c}.58 \\
(.03)\end{array}$ & $\begin{array}{c}.53 \\
(.07)\end{array}$ & $\begin{array}{l}.74 \\
(.02)\end{array}$ & $\begin{array}{c}.88 \\
(.02)\end{array}$ \\
\hline
\end{tabular}

Note: See data section for the definition of the variables. The reported numbers are nonparametric predictions of the transition probabilities. The numbers in parentheses are standard errors.

a Staying out of the labor market or unemployed, i.e., no earnings.

b Staying in the first quintile.

c Staying in the second quintile.

d Staying in the third quintile.

e Staying in the fourth quintile.

f Staying in the fifth quintile. 
TABLE IX: Mobility Measures of Earnings by Education and Experience Levels (Based on Breakdown by Quintiles)

\begin{tabular}{|c|c|c|c|c|c|c|c|c|}
\hline \multirow[b]{2}{*}{ Experience $\mathbf{a}^{\mathbf{a}}$} & \multicolumn{4}{|c|}{ Average Jump } & \multirow{2}{*}{$\frac{\text { Mean }}{100}$} & \multicolumn{2}{|c|}{ Reciprocal Exit } & \multirow{2}{*}{$\frac{\text { Time }}{700}$} \\
\hline & 100 & 300 & 500 & 700 & & 300 & 500 & \\
\hline
\end{tabular}

Elementary School Graduates:

$\begin{array}{lcccccccc}1980 & .17 & .17 & .16 & .16 & .53 & .53 & .52 & .51 \\ & (.01) & (.01) & (.03) & (.07) & (.03) & (.04) & (.08) & (.11) \\ 1982 & .14 & .14 & .13 & .13 & .50 & .48 & .46 & .46 \\ & (.01) & (.01) & (.02) & (.05) & (.03) & (.03) & (.04) & (.08) \\ 1984 & .13 & .13 & .14 & .17 & .46 & .45 & .46 & .52 \\ & (.01) & (.01) & (.01) & (.06) & (.02) & (.02) & (.03) & (.08) \\ 1986 & .14 & .14 & .15 & .15 & .48 & .48 & .48 & .49 \\ & (.01) & (.01) & (.01) & (.02) & .02) & (.02) & (.02) & (.06) \\ 1988 & .13 & .13 & .12 & .10 & .47 & .45 & .42 & .35 \\ & (.01) & (.01) & (.01) & (.01) & (.02) & (.01) & (.02) & (.03) \\ 1990 & .12 & .11 & .11 & .10 & .39 & .39 & .38 & .38 \\ & (.01) & (.01) & (.01) & (.01) & (.03) & (.02) & (.02) & (.02)\end{array}$

High School Graduates:

$\begin{array}{lcccccccc}1980 & .18 & .17 & .17 & .16 & .55 & .53 & .53 & .51 \\ & (.01) & (.01) & (.03) & (.06) & (.03) & (.03) & (.06) & (.11) \\ 1982 & .15 & .14 & .14 & .15 & .49 & .49 & .49 & .50 \\ & (.01) & (.01) & (.01) & (.05) & (.03) & (.03) & (.04) & (.08) \\ 1984 & .13 & .13 & .13 & .14 & .46 & .46 & .45 & .48 \\ & (.01) & (.01) & (.01) & (.04) & (.02) & (.02) & (.02) & (.07) \\ 1986 & .13 & .14 & .13 & .13 & .47 & .47 & .46 & .45 \\ & (.01) & .01) & (.01) & (.02) & (.02) & (.02) & (.02) & (.04) \\ 1988 & .12 & .12 & .11 & .10 & .43 & .42 & .39 & .36 \\ & (.01) & (.01) & (.01) & (.01) & (.01) & (.01) & (.01) & (.02) \\ 1990 & .10 & .10 & .10 & .09 & .37 & .37 & .36 & .36 \\ & (.01) & (.00) & (.00) & (.01) & (.02) & (.01) & (.01) & (.02)\end{array}$


TABLE IX (Continued)

\begin{tabular}{|c|c|c|c|c|c|c|c|c|}
\hline \multirow[b]{2}{*}{ Experience $^{\mathbf{a}}$} & \multicolumn{4}{|c|}{ Average Jump } & Mean & \multicolumn{3}{|c|}{ Reciprocal Exit Time } \\
\hline & 100 & 300 & 500 & 700 & 100 & 300 & 500 & 700 \\
\hline \multicolumn{9}{|c|}{ College Graduates: } \\
\hline 1980 & $\begin{array}{c}.14 \\
(.01)\end{array}$ & $\begin{array}{c}.14 \\
(.01)\end{array}$ & $\begin{array}{l}.14 \\
(.04)\end{array}$ & $\begin{array}{c}.13 \\
(.07)\end{array}$ & $\begin{array}{c}.45 \\
(.03)\end{array}$ & $\begin{array}{c}.45 \\
(.04)\end{array}$ & $\begin{array}{c}.46 \\
(.09)\end{array}$ & $\begin{array}{r}.44 \\
(.11)\end{array}$ \\
\hline 1982 & $\begin{array}{c}.14 \\
(.01)\end{array}$ & $\begin{array}{c}.14 \\
(.01)\end{array}$ & $\begin{array}{c}.15 \\
(.02)\end{array}$ & $\begin{array}{c}.16 \\
(.05)\end{array}$ & $\begin{array}{c}.49 \\
(.03)\end{array}$ & $\begin{array}{c}.49 \\
(.03)\end{array}$ & $\begin{array}{c}.50 \\
(.05)\end{array}$ & $\begin{array}{c}.53 \\
(.08)\end{array}$ \\
\hline 1984 & $\begin{array}{c}.15 \\
(.01)\end{array}$ & $\begin{array}{c}.14 \\
(.01)\end{array}$ & $\begin{array}{c}.13 \\
(.01)\end{array}$ & $\begin{array}{c}.13 \\
(.04)\end{array}$ & $\begin{array}{c}.48 \\
(.02)\end{array}$ & $\begin{array}{c}.46 \\
(.02)\end{array}$ & $\begin{array}{c}.44 \\
(.03)\end{array}$ & $\begin{array}{c}.42 \\
(.08)\end{array}$ \\
\hline 1986 & $\begin{array}{c}.12 \\
(.01)\end{array}$ & $\begin{array}{c}.12 \\
(.01)\end{array}$ & $\begin{array}{c}.12 \\
(.01)\end{array}$ & $\begin{array}{c}.12 \\
(.02)\end{array}$ & $\begin{array}{c}.44 \\
(.02)\end{array}$ & $\begin{array}{c}.44 \\
(.02)\end{array}$ & $\begin{array}{c}.42 \\
(.02)\end{array}$ & $\begin{array}{c}.41 \\
(.04)\end{array}$ \\
\hline 1988 & $\begin{array}{c}.11 \\
(.01)\end{array}$ & $\begin{array}{c}.11 \\
(.01)\end{array}$ & $\begin{array}{l}.10 \\
(.01)\end{array}$ & $\begin{array}{c}.09 \\
(.01)\end{array}$ & $\begin{array}{c}.40 \\
(.01)\end{array}$ & $\begin{array}{c}.39 \\
(.01)\end{array}$ & $\begin{array}{c}.37 \\
(.01)\end{array}$ & $\begin{array}{c}.35 \\
(.02)\end{array}$ \\
\hline 1990 & $\begin{array}{c}.09 \\
(.01)\end{array}$ & $\begin{array}{c}.10 \\
(.01)\end{array}$ & $\begin{array}{l}.10 \\
(.01)\end{array}$ & $\begin{array}{l}.10 \\
(.01)\end{array}$ & $\begin{array}{c}.33 \\
(.02)\end{array}$ & $\begin{array}{l}.34 \\
(.01)\end{array}$ & $\begin{array}{c}.35 \\
(.01)\end{array}$ & $\begin{array}{l}.35 \\
(.02)\end{array}$ \\
\hline
\end{tabular}

Note: See the exact definition for average quintile jump (AJ) and mean of the reciprocal exit time (MP) in the text. The numbers in parentheses are standard errors.

a Experience is measured in weeks. 
TABLE X: Conditional Staying Probabilities of Wages, by Quintiles

\begin{tabular}{|c|c|c|c|c|c|c|c|c|c|c|c|c|}
\hline & $\mathbf{0}^{\mathbf{a}}$ & $1^{b}$ & $2^{c}$ & $3^{d}$ & $4^{e}$ & $\mathbf{5}^{\mathrm{f}}$ & $\mathbf{0}^{\mathbf{a}}$ & $\mathbf{1}^{\mathbf{b}}$ & $2^{\mathbf{c}}$ & $3^{d}$ & $4^{e}$ & $5^{f}$ \\
\hline \multicolumn{13}{|c|}{ Elementary School Graduates (8 Years of Education): } \\
\hline & \multicolumn{6}{|c|}{100 Weeks of Experience } & \multicolumn{6}{|c|}{300 Weeks of Experience } \\
\hline 1980 & $\begin{array}{c}.80 \\
(.00)\end{array}$ & $\begin{array}{c}.28 \\
(.13)\end{array}$ & $\begin{array}{c}.29 \\
(.04)\end{array}$ & $\begin{array}{c}.30 \\
(.04)\end{array}$ & $\begin{array}{c}.34 \\
(.03)\end{array}$ & $\begin{array}{c}.06 \\
(.02)\end{array}$ & $\begin{array}{c}.50 \\
(.12)\end{array}$ & $\begin{array}{c}.40 \\
(.14)\end{array}$ & $\begin{array}{c}.30 \\
(.08)\end{array}$ & $\begin{array}{c}.31 \\
(.06)\end{array}$ & $\begin{array}{c}.41 \\
(.09)\end{array}$ & $\begin{array}{c}.37 \\
(.10)\end{array}$ \\
\hline 1984 & $\begin{array}{c}.84 \\
(.00)\end{array}$ & $\begin{array}{c}.39 \\
(.02)\end{array}$ & $\begin{array}{c}.36 \\
(.03)\end{array}$ & $\begin{array}{c}.36 \\
(.02)\end{array}$ & $\begin{array}{l}.40 \\
(.03)\end{array}$ & $\begin{array}{c}.49 \\
(.02)\end{array}$ & $\begin{array}{c}.59 \\
(.02)\end{array}$ & $\begin{array}{c}.39 \\
(.03)\end{array}$ & $\begin{array}{c}.38 \\
(.03)\end{array}$ & $\begin{array}{c}.39 \\
(.03)\end{array}$ & $\begin{array}{c}.46 \\
(.03)\end{array}$ & $\begin{array}{c}.33 \\
(.02)\end{array}$ \\
\hline 1987 & $\begin{array}{c}.79 \\
(.00)\end{array}$ & $\begin{array}{c}.40 \\
(.02)\end{array}$ & $\begin{array}{c}.36 \\
(.02)\end{array}$ & $\begin{array}{c}.42 \\
(.03)\end{array}$ & $\begin{array}{c}.54 \\
(.03)\end{array}$ & $\begin{array}{c}.55 \\
(.02)\end{array}$ & $\begin{array}{c}.61 \\
(.01)\end{array}$ & $\begin{array}{c}.45 \\
(.02)\end{array}$ & $\begin{array}{c}.39 \\
(.02)\end{array}$ & $\begin{array}{c}.44 \\
(.03)\end{array}$ & $\begin{array}{c}.53 \\
(.02)\end{array}$ & $\begin{array}{c}.52 \\
(.02)\end{array}$ \\
\hline 1991 & $\begin{array}{c}.81 \\
(.02)\end{array}$ & $\begin{array}{c}.48 \\
(.05)\end{array}$ & $\begin{array}{c}.31 \\
(.05)\end{array}$ & $\begin{array}{c}.07 \\
(.05)\end{array}$ & $\begin{array}{c}.57 \\
(.10)\end{array}$ & $\begin{array}{c}.50 \\
(.06)\end{array}$ & $\begin{array}{c}.71 \\
(.01)\end{array}$ & $\begin{array}{c}.52 \\
(.02)\end{array}$ & $\begin{array}{c}.40 \\
(.02)\end{array}$ & $\begin{array}{c}.39 \\
(.03)\end{array}$ & $\begin{array}{c}.50 \\
(.03)\end{array}$ & $\begin{array}{c}.50 \\
(.04)\end{array}$ \\
\hline & \multicolumn{6}{|c|}{500 Weeks of Experience } & \multicolumn{6}{|c|}{700 Weeks of Experience } \\
\hline 1980 & $\begin{array}{c}.16 \\
(.27)\end{array}$ & $\begin{array}{c}.32 \\
(.21)\end{array}$ & $\begin{array}{c}.30 \\
(.12)\end{array}$ & $\begin{array}{c}.31 \\
(.11)\end{array}$ & $\begin{array}{c}.46 \\
(.27)\end{array}$ & $\begin{array}{c}.37 \\
(.26)\end{array}$ & $\begin{array}{c}.05 \\
(.29)\end{array}$ & $\begin{array}{c}.31 \\
(.24)\end{array}$ & $\begin{array}{c}.30 \\
(.26)\end{array}$ & $\begin{array}{c}.31 \\
(.28)\end{array}$ & $\begin{array}{c}.52 \\
(.28)\end{array}$ & $\begin{array}{c}.28 \\
(.29)\end{array}$ \\
\hline 1984 & $\begin{array}{c}.61 \\
(.16)\end{array}$ & $\begin{array}{c}.38 \\
(.06)\end{array}$ & $\begin{array}{c}.39 \\
(.08)\end{array}$ & $\begin{array}{c}.23 \\
(.10)\end{array}$ & $\begin{array}{c}.47 \\
(.05)\end{array}$ & $\begin{array}{c}.45 \\
(.06)\end{array}$ & $\begin{array}{l}.31 \\
(.29)\end{array}$ & $\begin{array}{c}.32 \\
(.25)\end{array}$ & $\begin{array}{c}.37 \\
(.15)\end{array}$ & $\begin{array}{c}.28 \\
(.25)\end{array}$ & $\begin{array}{c}.47 \\
(.11)\end{array}$ & $\begin{array}{c}.55 \\
(.25)\end{array}$ \\
\hline 1987 & $\begin{array}{c}.37 \\
(.03)\end{array}$ & $\begin{array}{c}.52 \\
(.03)\end{array}$ & $\begin{array}{c}.42 \\
(.03)\end{array}$ & $\begin{array}{c}.45 \\
(.03)\end{array}$ & $\begin{array}{c}.53 \\
(.03)\end{array}$ & $\begin{array}{c}.51 \\
(.02)\end{array}$ & $\begin{array}{c}.34 \\
(.23)\end{array}$ & $\begin{array}{c}.58 \\
(.11)\end{array}$ & $\begin{array}{c}.47 \\
(.07)\end{array}$ & $\begin{array}{c}.47 \\
(.07)\end{array}$ & $\begin{array}{c}.51 \\
(.07)\end{array}$ & $\begin{array}{c}.51 \\
(.13)\end{array}$ \\
\hline 1991 & $\begin{array}{c}.64 \\
(.02)\end{array}$ & $\begin{array}{c}.54 \\
(.02)\end{array}$ & $\begin{array}{c}.56 \\
(.02)\end{array}$ & $\begin{array}{c}.61 \\
(.03)\end{array}$ & $\begin{array}{c}.54 \\
(.03)\end{array}$ & $\begin{array}{c}.47 \\
(.04)\end{array}$ & $\begin{array}{c}.50 \\
(.05)\end{array}$ & $\begin{array}{c}.55 \\
(.04)\end{array}$ & $\begin{array}{c}.61 \\
(.03)\end{array}$ & $\begin{array}{c}.64 \\
(.05)\end{array}$ & $\begin{array}{c}.62 \\
(.04)\end{array}$ & $\begin{array}{c}.61 \\
(.05)\end{array}$ \\
\hline \multicolumn{13}{|l|}{ High } \\
\hline & \multicolumn{6}{|c|}{100 Weeks of Experience } & \multicolumn{6}{|c|}{300 Weeks of Experience } \\
\hline 1980 & $\begin{array}{c}.56 \\
(.00)\end{array}$ & $\begin{array}{c}.23 \\
(.12)\end{array}$ & $\begin{array}{c}.30 \\
(.02)\end{array}$ & $\begin{array}{c}.31 \\
(.04)\end{array}$ & $\begin{array}{l}.40 \\
(.02)\end{array}$ & $\begin{array}{c}.39 \\
(.01)\end{array}$ & $\begin{array}{c}.38 \\
(.04)\end{array}$ & $\begin{array}{c}.20 \\
(.13)\end{array}$ & $\begin{array}{c}.31 \\
(.04)\end{array}$ & $\begin{array}{c}.32 \\
(.05)\end{array}$ & $\begin{array}{c}.46 \\
(.04)\end{array}$ & $\begin{array}{c}.48 \\
(.04)\end{array}$ \\
\hline 1984 & $\begin{array}{c}.65 \\
(.00)\end{array}$ & $\begin{array}{c}.37 \\
(.01)\end{array}$ & $\begin{array}{c}.37 \\
(.02)\end{array}$ & $\begin{array}{c}.39 \\
(.01)\end{array}$ & $\begin{array}{l}.46 \\
(.02)\end{array}$ & $\begin{array}{c}.44 \\
(.01)\end{array}$ & $\begin{array}{c}.51 \\
(.00)\end{array}$ & $\begin{array}{c}.36 \\
(.02)\end{array}$ & $\begin{array}{c}.39 \\
(.02)\end{array}$ & $\begin{array}{c}.49 \\
(.01)\end{array}$ & $\begin{array}{c}.49 \\
(.02)\end{array}$ & $\begin{array}{c}.60 \\
(.01)\end{array}$ \\
\hline 1987 & $\begin{array}{c}.70 \\
(.00)\end{array}$ & $\begin{array}{c}.45 \\
(.01)\end{array}$ & $\begin{array}{c}.39 \\
(.02)\end{array}$ & $\begin{array}{c}.42 \\
(.02)\end{array}$ & $\begin{array}{c}.48 \\
(.02)\end{array}$ & $\begin{array}{c}.64 \\
(.01)\end{array}$ & $\begin{array}{c}.62 \\
(.00)\end{array}$ & $\begin{array}{c}.51 \\
(.01)\end{array}$ & $\begin{array}{c}.40 \\
(.01)\end{array}$ & $\begin{array}{c}.45 \\
(.02)\end{array}$ & $\begin{array}{c}.44 \\
(.01)\end{array}$ & $\begin{array}{c}.61 \\
(.01)\end{array}$ \\
\hline 1991 & $\begin{array}{c}.80 \\
(.02)\end{array}$ & $\begin{array}{c}.53 \\
(.04)\end{array}$ & $\begin{array}{c}.36 \\
(.04)\end{array}$ & $\begin{array}{c}.20 \\
(.05)\end{array}$ & $\begin{array}{c}.54 \\
(.06)\end{array}$ & $\begin{array}{c}.41 \\
(.05)\end{array}$ & $\begin{array}{c}.69 \\
(.01)\end{array}$ & $\begin{array}{c}.53 \\
(.01)\end{array}$ & $\begin{array}{c}.49 \\
(.01)\end{array}$ & $\begin{array}{c}.46 \\
(.02)\end{array}$ & $\begin{array}{c}.51 \\
(.02)\end{array}$ & $\begin{array}{c}.60 \\
(.02)\end{array}$ \\
\hline & \multicolumn{6}{|c|}{500 Weeks of Experience } & \multicolumn{6}{|c|}{700 Weeks of Experience } \\
\hline 1980 & $\begin{array}{c}.26 \\
(.24)\end{array}$ & $\begin{array}{c}.22 \\
(.20)\end{array}$ & $\begin{array}{c}.31 \\
(.10)\end{array}$ & $\begin{array}{c}.32 \\
(.09)\end{array}$ & $\begin{array}{c}.49 \\
(.20)\end{array}$ & $\begin{array}{c}.40 \\
(.24)\end{array}$ & $\begin{array}{c}.11 \\
(.29)\end{array}$ & $\begin{array}{c}.26 \\
(.24)\end{array}$ & $\begin{array}{c}.31 \\
(.23)\end{array}$ & $\begin{array}{c}.32 \\
(.24)\end{array}$ & $\begin{array}{c}.51 \\
(.28)\end{array}$ & $\begin{array}{c}.28 \\
(.29)\end{array}$ \\
\hline 1984 & $\begin{array}{c}.25 \\
(.05)\end{array}$ & $\begin{array}{l}.36 \\
(.04)\end{array}$ & $\begin{array}{l}.40 \\
(.05)\end{array}$ & $\begin{array}{c}.61 \\
(.03)\end{array}$ & $\begin{array}{c}.48 \\
(.03)\end{array}$ & $\begin{array}{c}.65 \\
(.03)\end{array}$ & $\begin{array}{c}.05 \\
(.27)\end{array}$ & $\begin{array}{c}.33 \\
(.16)\end{array}$ & $\begin{array}{c}.37 \\
(.15)\end{array}$ & $\begin{array}{c}.71 \\
(.24)\end{array}$ & $\begin{array}{c}.48 \\
(.08)\end{array}$ & $\begin{array}{l}.71 \\
(.23)\end{array}$ \\
\hline 1987 & $\begin{array}{c}.44 \\
(.01)\end{array}$ & $\begin{array}{c}.55 \\
(.02)\end{array}$ & $\begin{array}{c}.43 \\
(.02)\end{array}$ & $\begin{array}{c}.47 \\
(.02)\end{array}$ & $\begin{array}{c}.50 \\
(.02)\end{array}$ & $\begin{array}{c}.55 \\
(.01)\end{array}$ & $\begin{array}{c}.52 \\
(.06)\end{array}$ & $\begin{array}{c}.67 \\
(.05)\end{array}$ & $\begin{array}{c}.45 \\
(.05)\end{array}$ & $\begin{array}{c}.49 \\
(.04)\end{array}$ & $\begin{array}{c}.54 \\
(.04)\end{array}$ & $\begin{array}{l}.54 \\
(.07)\end{array}$ \\
\hline 1991 & $\begin{array}{c}.61 \\
(.01)\end{array}$ & $\begin{array}{c}.54 \\
(.01)\end{array}$ & $\begin{array}{c}.54 \\
(.01)\end{array}$ & $\begin{array}{c}.57 \\
(.01)\end{array}$ & $\begin{array}{c}.56 \\
(.01)\end{array}$ & $\begin{array}{c}.52 \\
(.01)\end{array}$ & $\begin{array}{c}.53 \\
(.01)\end{array}$ & $\begin{array}{c}.54 \\
(.02)\end{array}$ & $\begin{array}{c}.58 \\
(.01)\end{array}$ & $\begin{array}{c}.58 \\
(.01)\end{array}$ & $\begin{array}{c}.62 \\
(.02)\end{array}$ & $\begin{array}{c}.64 \\
(.02)\end{array}$ \\
\hline
\end{tabular}


TABLE X (Continued)

\begin{tabular}{|c|c|c|c|c|c|c|c|c|c|c|c|c|}
\hline & $0^{\mathbf{a}}$ & $1^{b}$ & $2^{c}$ & $3^{d}$ & $4^{e}$ & $5^{f}$ & $0^{\mathbf{a}}$ & $1^{b}$ & $2^{c}$ & $3^{d}$ & $4^{e}$ & $5^{f}$ \\
\hline \multicolumn{13}{|c|}{ College Graduates (16 Years of Education): } \\
\hline & \multicolumn{6}{|c|}{100 Weeks of Experience } & \multicolumn{6}{|c|}{300 Weeks of Experience } \\
\hline 1980 & .47 & .00 & .31 & .32 & .37 & .54 & .56 & .00 & .31 & .32 & .39 & .70 \\
\hline \multirow{2}{*}{1984} & .35 & .33 & .36 & .43 & .47 & .71 & .58 & .32 & .36 & .37 & .48 & .77 \\
\hline & $(.01)$ & $(.02)$ & $(.02)$ & $(.02)$ & $(.02)$ & $(.01)$ & $(.01)$ & $(.03)$ & $(.03)$ & $(.02)$ & $(.03)$ & $(.01)$ \\
\hline \multirow[t]{2}{*}{1987} & .59 & .48 & .37 & .40 & .48 & .63 & .49 & .44 & .38 & .42 & .48 & .71 \\
\hline & $(.01)$ & $(.02)$ & $(.02)$ & $(.02)$ & $(.02)$ & $(.01)$ & $(.01)$ & $(.02)$ & $(.02)$ & $(.02)$ & $(.02)$ & $(.01)$ \\
\hline \multirow[t]{2}{*}{1991} & .75 & .47 & .61 & .40 & .49 & .62 & .70 & .50 & .57 & .38 & .51 & .69 \\
\hline & \multicolumn{6}{|c|}{500 Weeks of Experience } & \multicolumn{6}{|c|}{700 Weeks of Experience } \\
\hline \multirow[t]{2}{*}{1980} & .72 & .04 & .31 & .33 & .40 & .83 & .56 & .06 & .30 & .33 & .40 & .74 \\
\hline & $(.27)$ & $(.22)$ & $(.14)$ & $(.13)$ & $(.28)$ & $(.27)$ & $(.29)$ & $(.25)$ & $(.28)$ & $(.28)$ & $(.28)$ & $(.29)$ \\
\hline \multirow[t]{2}{*}{1984} & .52 & .34 & .37 & .52 & .49 & .82 & .28 & .38 & .37 & .66 & .50 & .90 \\
\hline & $(.12)$ & $(.06)$ & $(.09)$ & $(.08)$ & $(.04)$ & $(.04)$ & $(.28)$ & $(.22)$ & $(.15)$ & $(.25)$ & $(.09)$ & $(.27)$ \\
\hline \multirow[t]{2}{*}{1987} & .54 & .35 & .42 & .44 & .52 & .77 & .58 & .40 & .44 & .45 & .51 & .80 \\
\hline & $(.02)$ & $(.03)$ & $(.03)$ & $(.03)$ & $(.02)$ & $(.01)$ & $(.19)$ & $(.06)$ & $(.06)$ & $(.06)$ & $(.05)$ & $(.07)$ \\
\hline \multirow[t]{2}{*}{1991} & .66 & .50 & .53 & .44 & .50 & .74 & .64 & .48 & .59 & .51 & .51 & .79 \\
\hline & $(.01)$ & $(.01)$ & $(.02)$ & $(.01)$ & $(.01)$ & $(.01)$ & $(.02)$ & $(.02)$ & $(.03)$ & $(.02)$ & $(.02)$ & $(.01)$ \\
\hline
\end{tabular}

Note: See data section for the definition of the variables. The reported numbers are nonparametric predictions of the transition probabilities. The numbers in parentheses are standard errors.

a Staying out of the labor market or unemployed, i.e. no wage.

b Staying in the first quintile.

c Staying in the second quintile.

d Staying in the third quintile.

e Staying in the fourth quintile.

f Staying in the fifth quintile. 
TABLE XI: Mobility Measures of Wages by Education and Experience Levels (Based on Breakdown by Quintiles)

\begin{tabular}{|c|c|c|c|c|c|c|c|c|}
\hline \multirow[b]{2}{*}{ Experience $\mathbf{a}^{\mathbf{a}}$} & \multicolumn{4}{|c|}{ Average Jump } & \multicolumn{4}{|c|}{ Mean Reciprocal Exit Time } \\
\hline & 100 & 300 & 500 & 700 & 100 & 300 & 500 & 700 \\
\hline \multicolumn{9}{|c|}{ Elementary School Graduates: } \\
\hline 1980 & $\begin{array}{c}.28 \\
(.02)\end{array}$ & $\begin{array}{c}.28 \\
(.03)\end{array}$ & $\begin{array}{c}.31 \\
(.07)\end{array}$ & $\begin{array}{c}.33 \\
(.08)\end{array}$ & $\begin{array}{c}.65 \\
(.02)\end{array}$ & $\begin{array}{c}.62 \\
(.04)\end{array}$ & $\begin{array}{c}.68 \\
(.09)\end{array}$ & $\begin{array}{c}.70 \\
(.11)\end{array}$ \\
\hline 1982 & $\begin{array}{c}.25 \\
(.01)\end{array}$ & $\begin{array}{c}.21 \\
(.01)\end{array}$ & $\begin{array}{c}.18 \\
(.05)\end{array}$ & $\begin{array}{c}.12 \\
(.08)\end{array}$ & $\begin{array}{c}.58 \\
(.01)\end{array}$ & $\begin{array}{c}.47 \\
(.02)\end{array}$ & $\begin{array}{c}.43 \\
(.06)\end{array}$ & $\begin{array}{c}.35 \\
(.11)\end{array}$ \\
\hline 1984 & $\begin{array}{c}.22 \\
(.00)\end{array}$ & $\begin{array}{c}.26 \\
(.01)\end{array}$ & $\begin{array}{c}.27 \\
(.03)\end{array}$ & $\begin{array}{c}.29 \\
(.08)\end{array}$ & $\begin{array}{c}.53 \\
(.01)\end{array}$ & $\begin{array}{c}.58 \\
(.01)\end{array}$ & $\begin{array}{c}.58 \\
(.04)\end{array}$ & $\begin{array}{c}.62 \\
(.09)\end{array}$ \\
\hline 1986 & $\begin{array}{l}.18 \\
(.00)\end{array}$ & $\begin{array}{c}.19 \\
(.01)\end{array}$ & $\begin{array}{c}.17 \\
(.01)\end{array}$ & $\begin{array}{l}.18 \\
(.06)\end{array}$ & $\begin{array}{c}.49 \\
(.01)\end{array}$ & $\begin{array}{c}.50 \\
(.01)\end{array}$ & $\begin{array}{c}.43 \\
(.02)\end{array}$ & $\begin{array}{c}.43 \\
(.07)\end{array}$ \\
\hline 1988 & $\begin{array}{l}.18 \\
(.01)\end{array}$ & $\begin{array}{c}.23 \\
(.01)\end{array}$ & $\begin{array}{c}.20 \\
(.01)\end{array}$ & $\begin{array}{l}.19 \\
(.03)\end{array}$ & $\begin{array}{c}.51 \\
(.02)\end{array}$ & $\begin{array}{c}.54 \\
(.01)\end{array}$ & $\begin{array}{c}.50 \\
(.01)\end{array}$ & $\begin{array}{c}.50 \\
(.04)\end{array}$ \\
\hline 1991 & $\begin{array}{c}.23 \\
(.01)\end{array}$ & $\begin{array}{c}.22 \\
(.01)\end{array}$ & $\begin{array}{c}.19 \\
(.01)\end{array}$ & $\begin{array}{l}.18 \\
(.01)\end{array}$ & $\begin{array}{c}.54 \\
(.02)\end{array}$ & $\begin{array}{c}.50 \\
(.01)\end{array}$ & $\begin{array}{l}.44 \\
(.01)\end{array}$ & $\begin{array}{c}.41 \\
(.02)\end{array}$ \\
\hline
\end{tabular}

High School Graduates:

$\begin{array}{lcccccccc}1980 & .26 & .28 & .30 & .32 & .63 & .64 & .67 & .70 \\ & (.01) & (.02) & (.06) & (.08) & (.02) & (.03) & (.08) & (.11) \\ 1982 & .21 & .22 & .19 & .17 & .55 & .57 & .54 & .51 \\ & (.01) & (.01) & (.02) & (.08) & (.00) & (.01) & (.04) & (.11) \\ 1984 & .21 & .20 & .23 & .25 & .55 & .53 & .54 & .56 \\ & (.00) & (.00) & (.01) & (.06) & (.01) & (.01) & (.02) & (.08) \\ 1986 & .18 & .20 & .22 & .25 & .50 & .50 & .52 & .56 \\ & (.00) & (.00) & (.00) & (.03) & (.01) & (.01) & (.01) & (.04) \\ 1988 & .19 & .20 & .20 & .19 & .50 & .51 & .50 & .50 \\ & (.00) & (.00) & (.00) & (.01) & .01) & (.01) & (.01) & (.02) \\ 1991 & .19 & .18 & .18 & .17 & .53 & .45 & .44 & .42 \\ & (.01) & (.00) & (.00) & (.00) & (.02) & (.01) & (.00) & (.01)\end{array}$


TABLE XI (Continued)

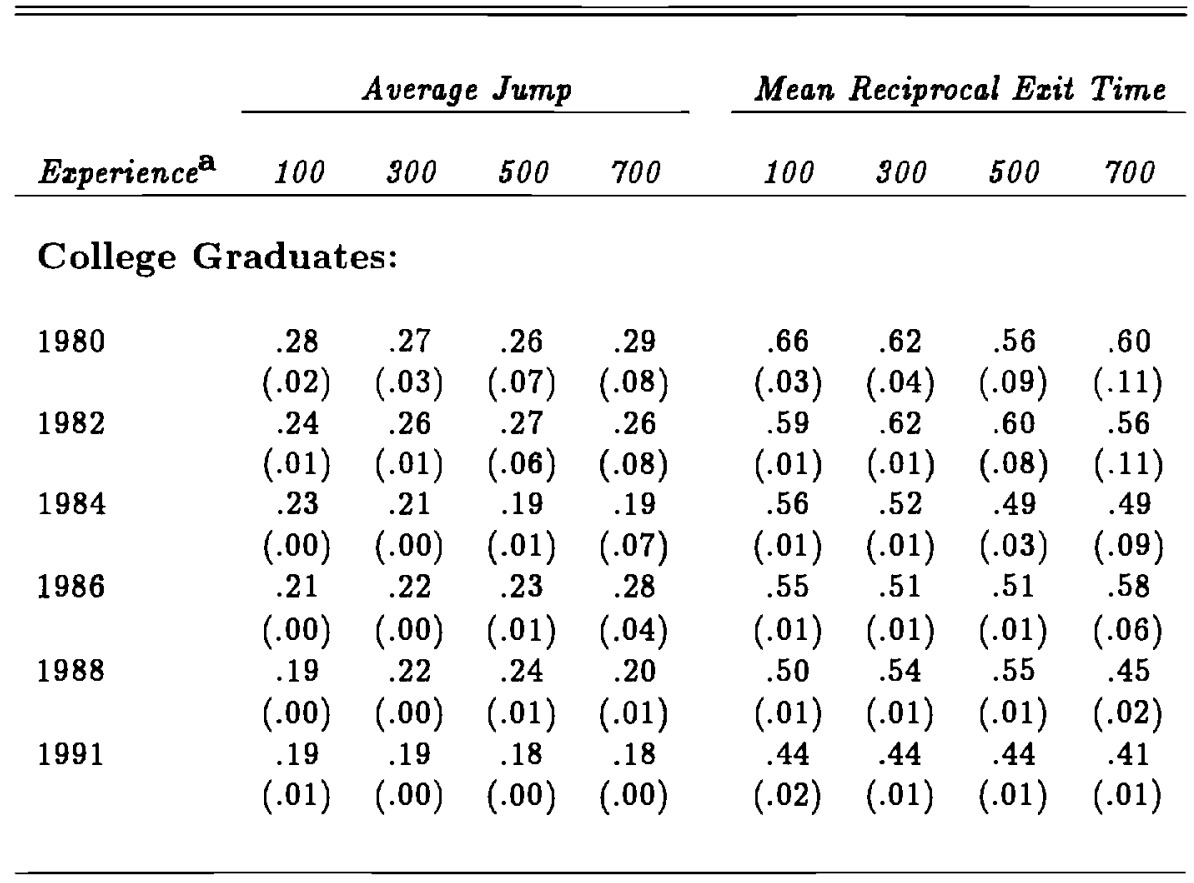

Note: See the exact definition for average quintile jump (AJ) and mean of the reciprocal exit time (MP) in the text. The numbers in parentheses are standard errors.

a Experience is measured in weeks. 
Figure 1: Total Wage Mobility

a. Consistent Sample-Horizon Begins in 1981

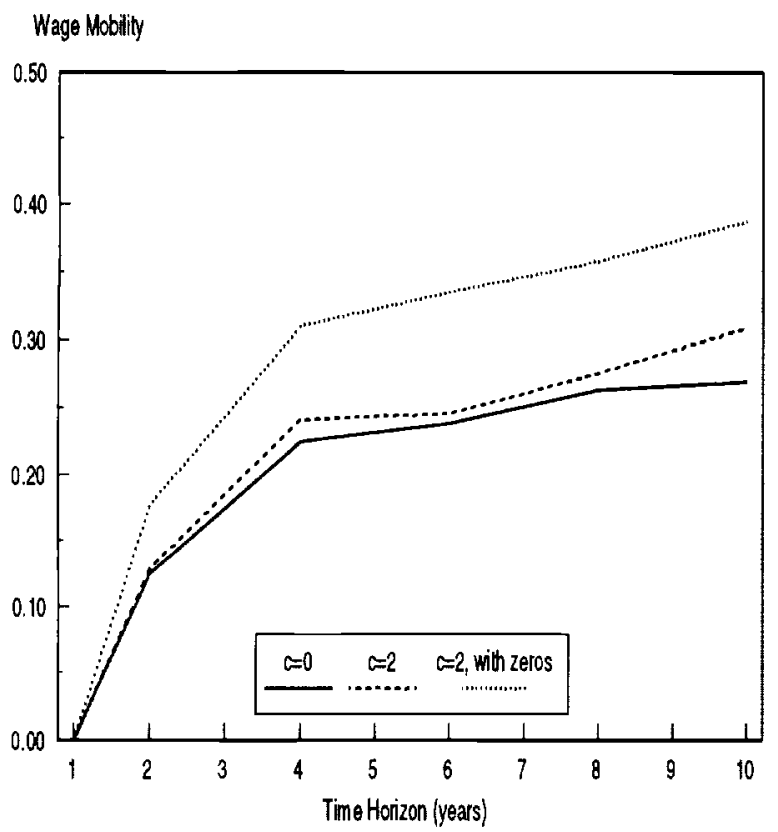

c. Maximum Sample-Horizon Begins in 1981

Wage Mobility

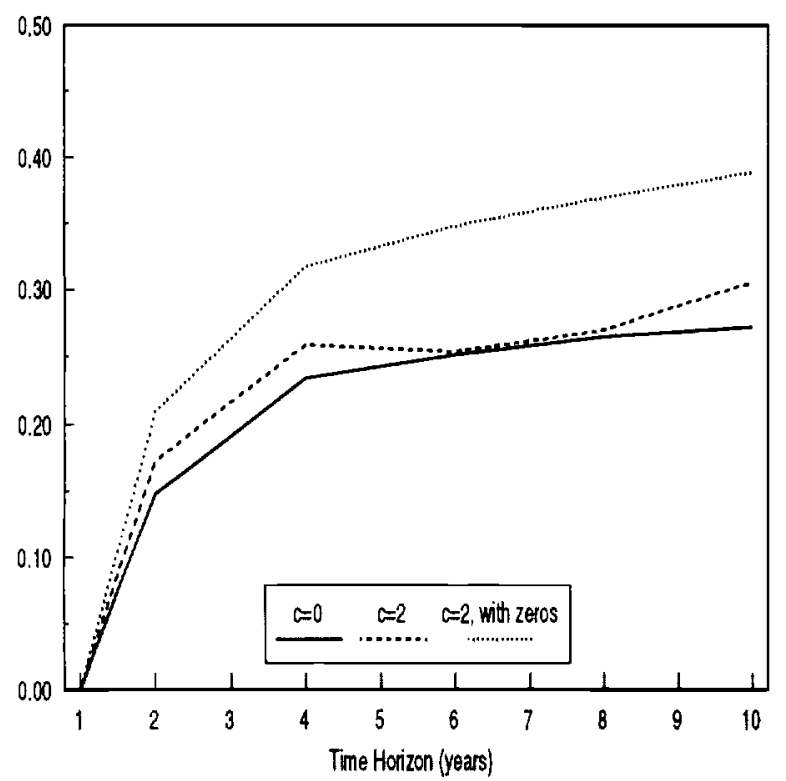

b. Consistent Sample-Horizon Ends in 1991

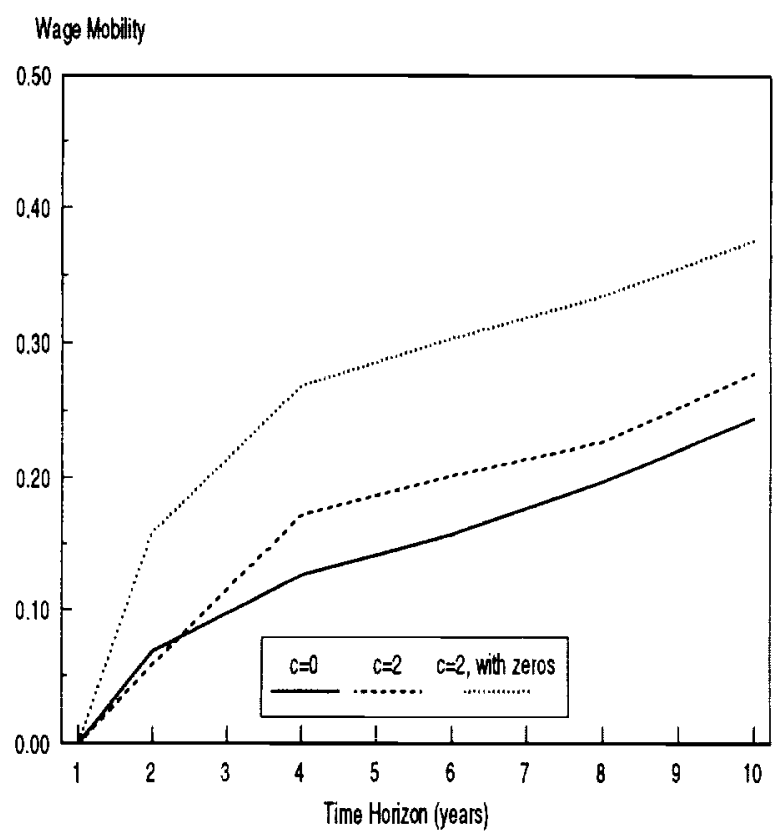

d. Maximum Sample-Horizon Ends in 1991

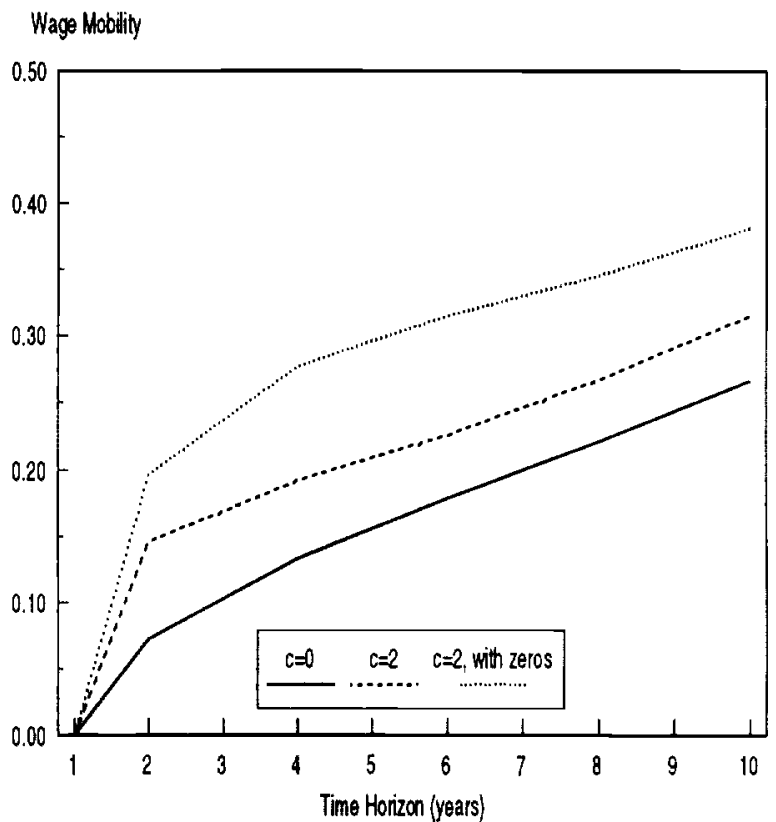


Figure 2: Total Wage Mobility as a Function of $c$ for Time Horizons Beginning in 1981, Maximum Sample

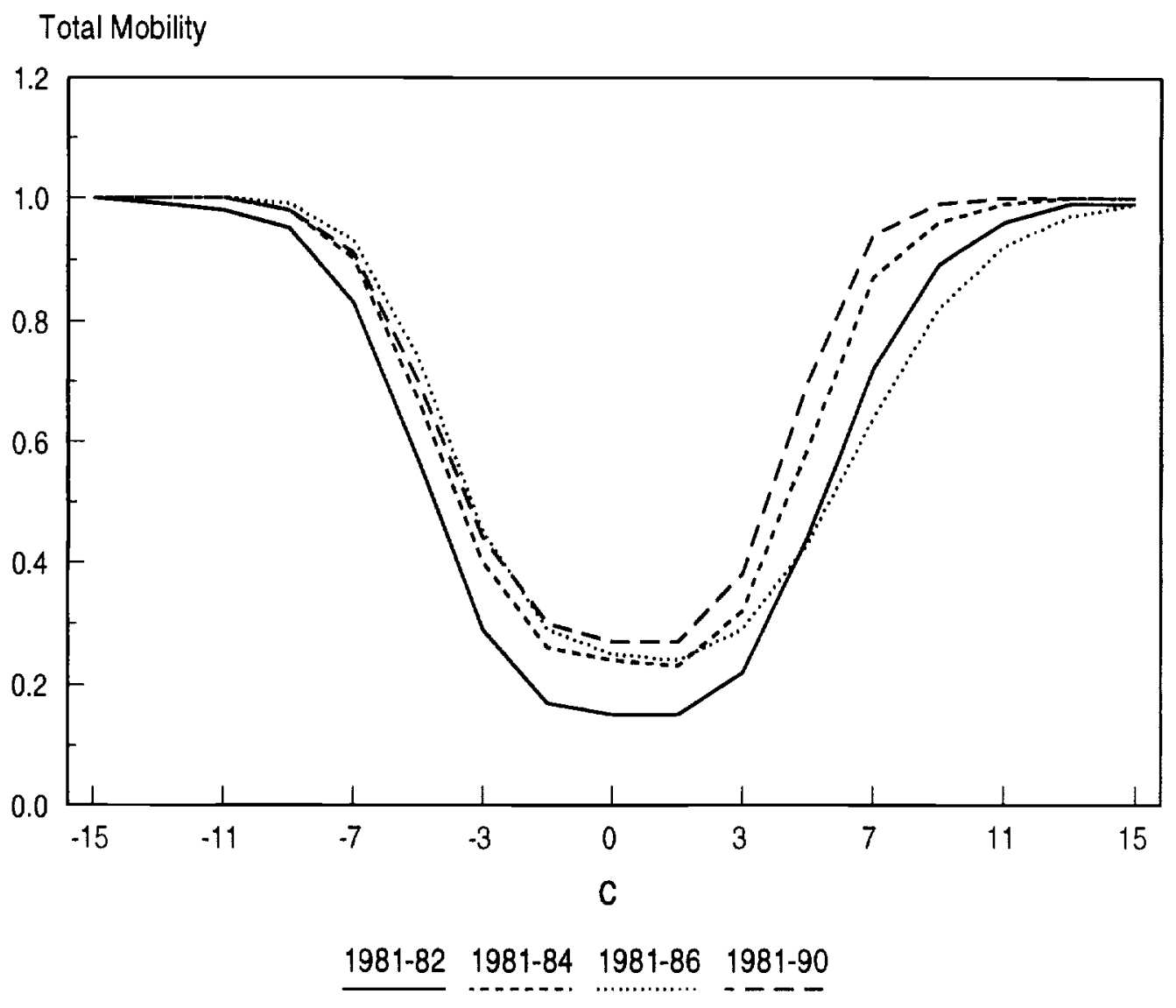


Figure 3: Total Earnings Mobility

a. Consistent Sample, Horizon Begins in 1981

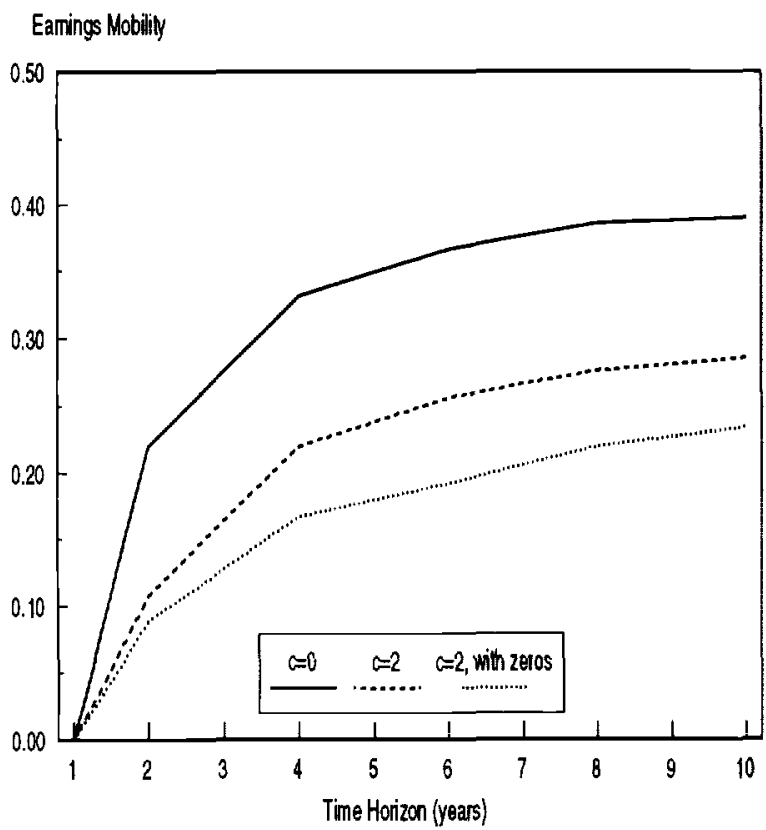

c. Maximum Sample, Honizon Begins in 1981

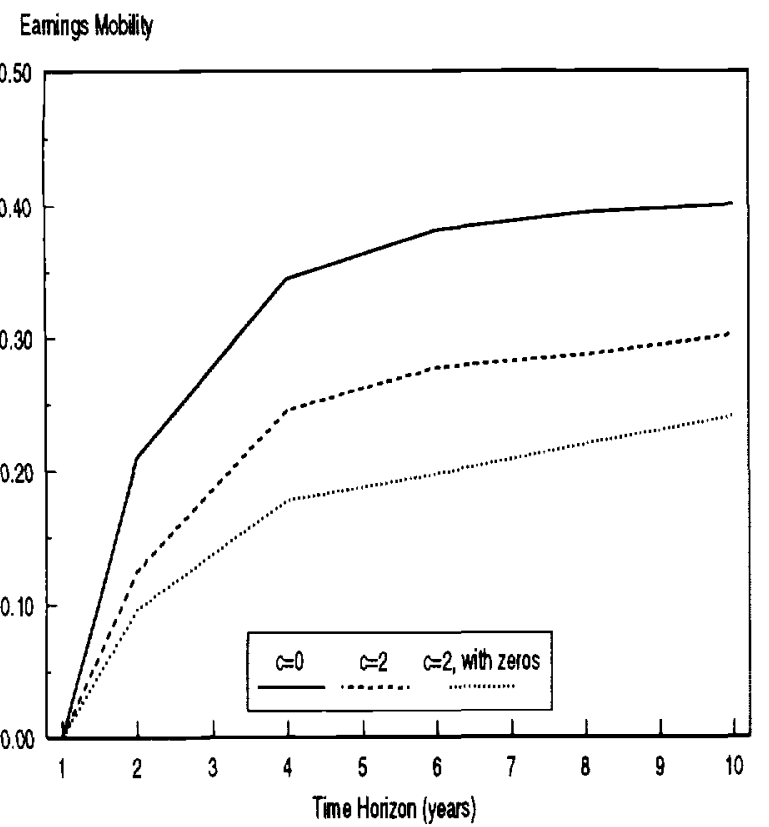

b. Consistent Sample, Horizon Ends in 1991

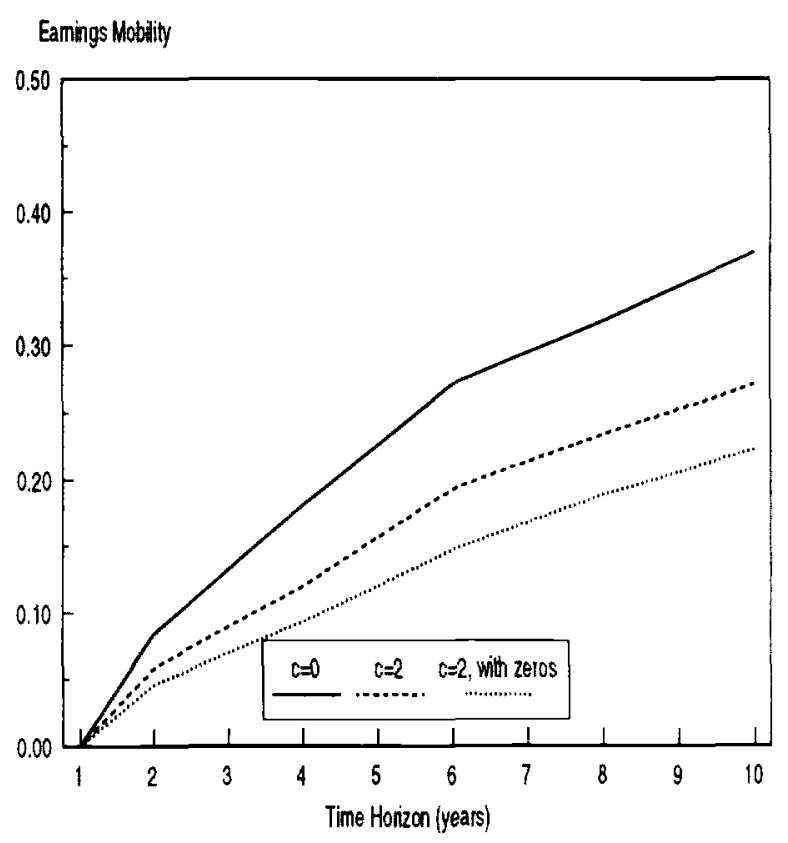

d. Maximum Sample, Horizon Ends in 1991

Eamings Moblity

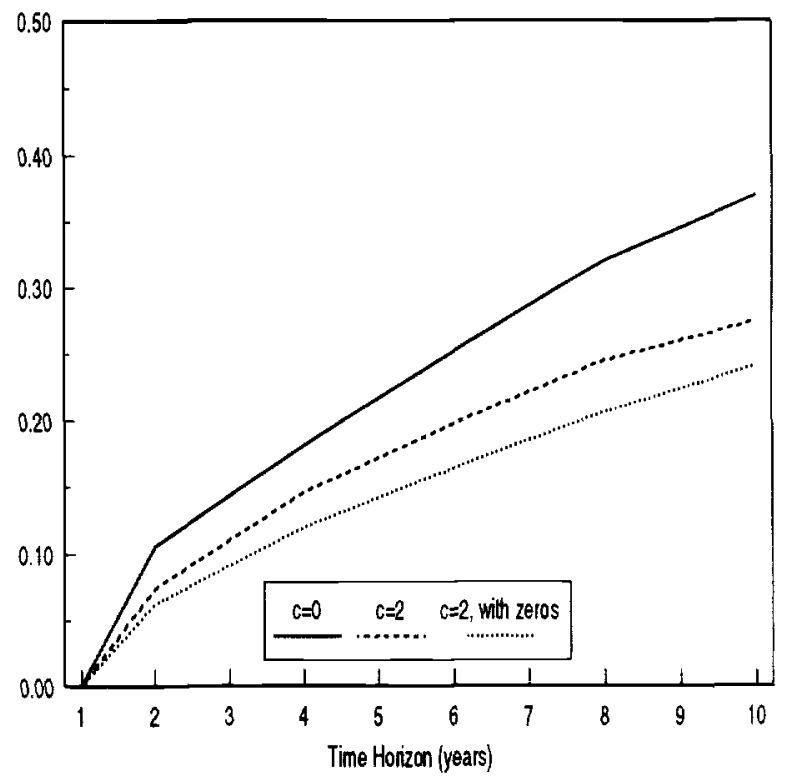




\section{Figure 4: Unconditional Staying Probabilities, by Quintiles}

\section{a. Earnings}

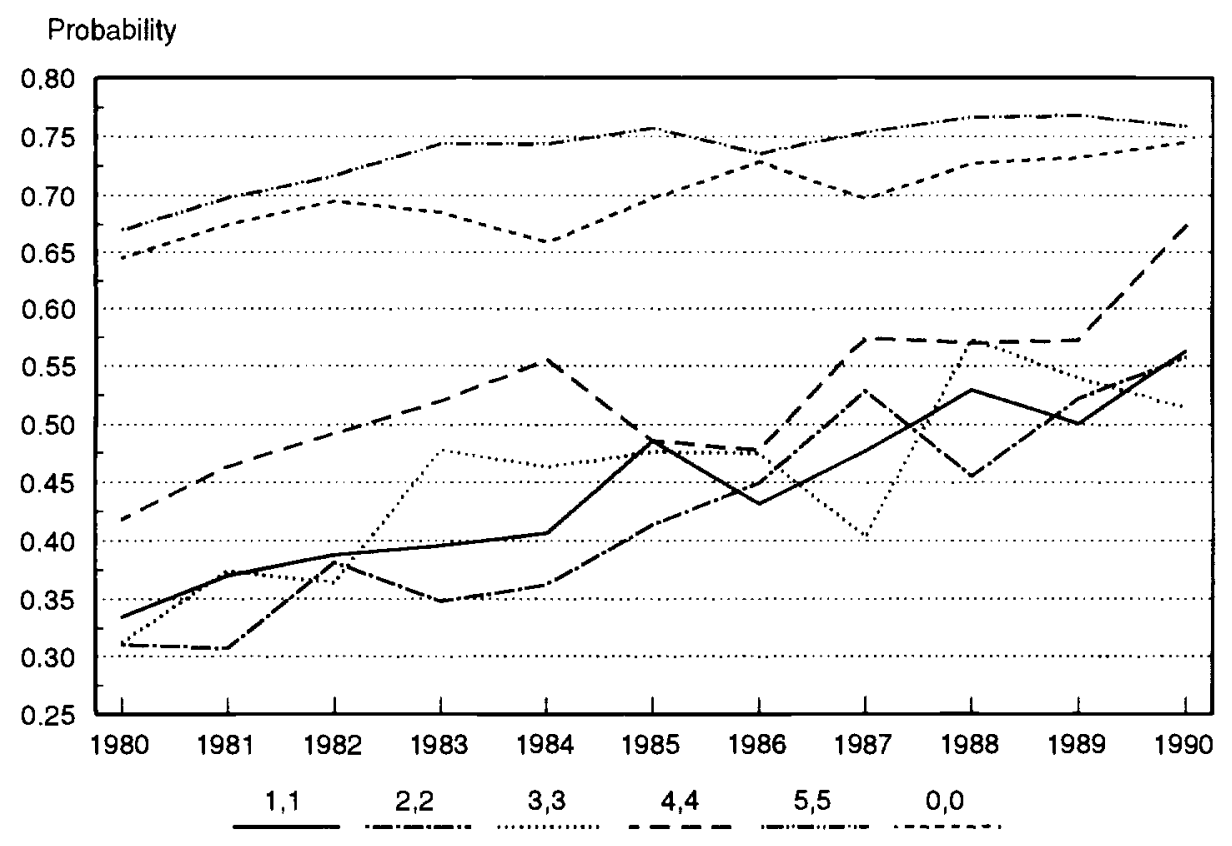

b. Wages

Probability

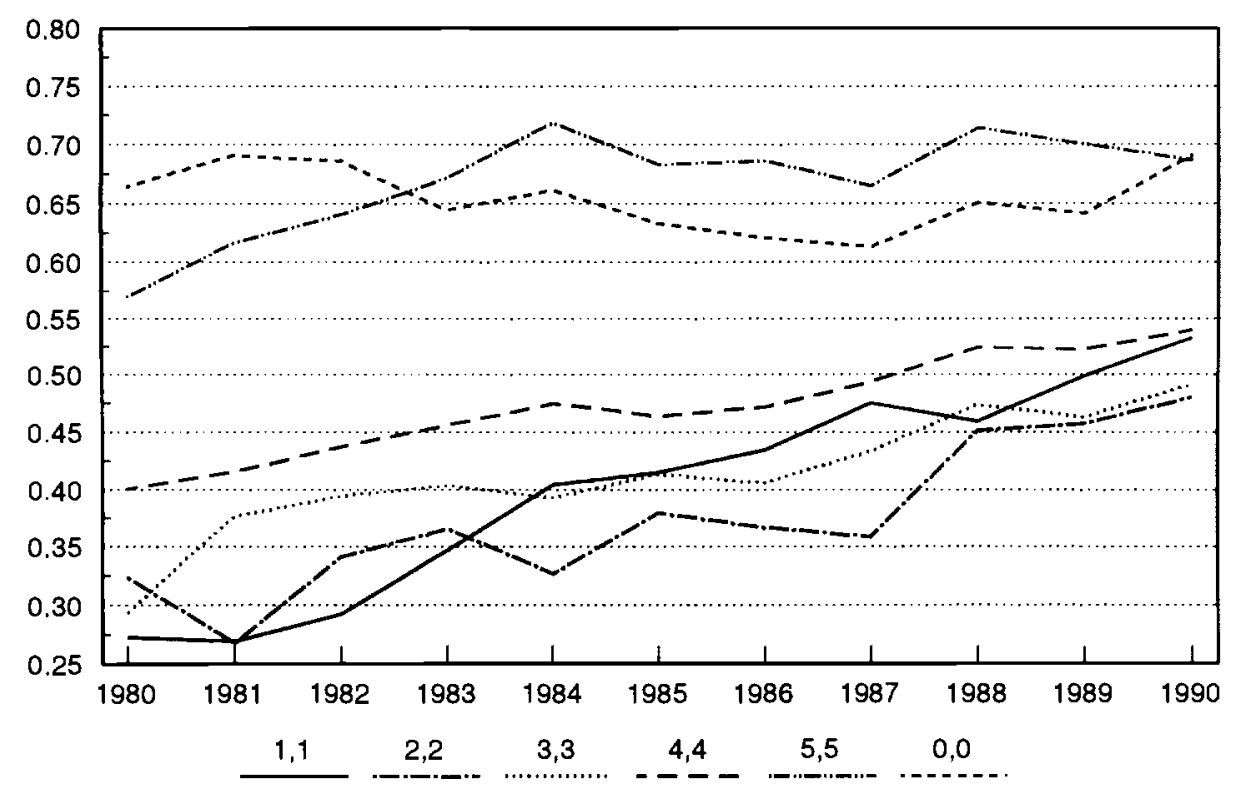

Note: The notation $\mathbf{2 , 2}$ denotes the probability of staying in the second quintile, and similarly for the other quintiles. The notation 0,0 denotes staying outside the distribution. 


\section{Figure 5: Conditional Staying Probabilities of Earnings, by Quintiles Elementary School Graduates}

\section{a. 100 Weeks of Experience}

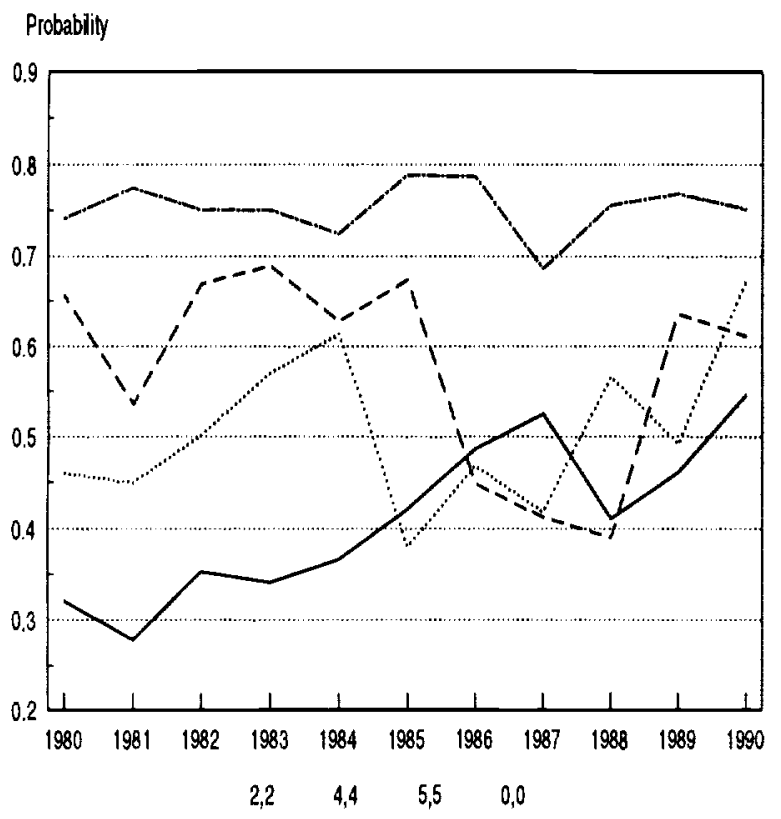

c. 500 Weeks of Experience

Probability

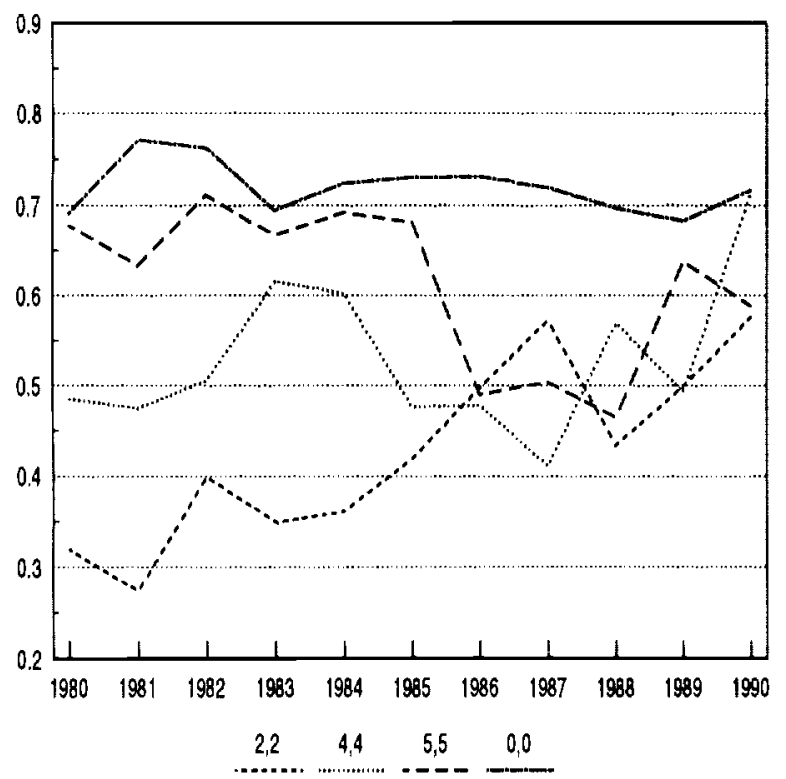

\section{b. 300 Weeks of Expenience}

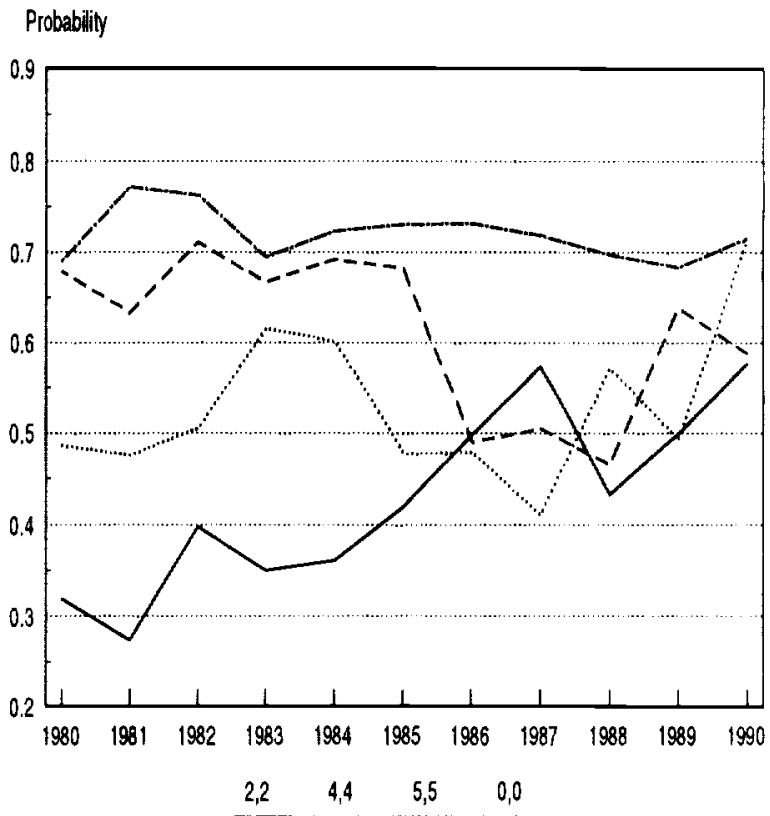

Note: The notation 2,2 denotes the probability of staying in the second quintile, and similarly for the other quintiles. The notation 0,0 denotes staying outside the distribution. 


\section{Figure 6: Conditional Staying Probabilities of Earnings, by Quintiles High School Graduates}

a. 100 Weeks of Experience

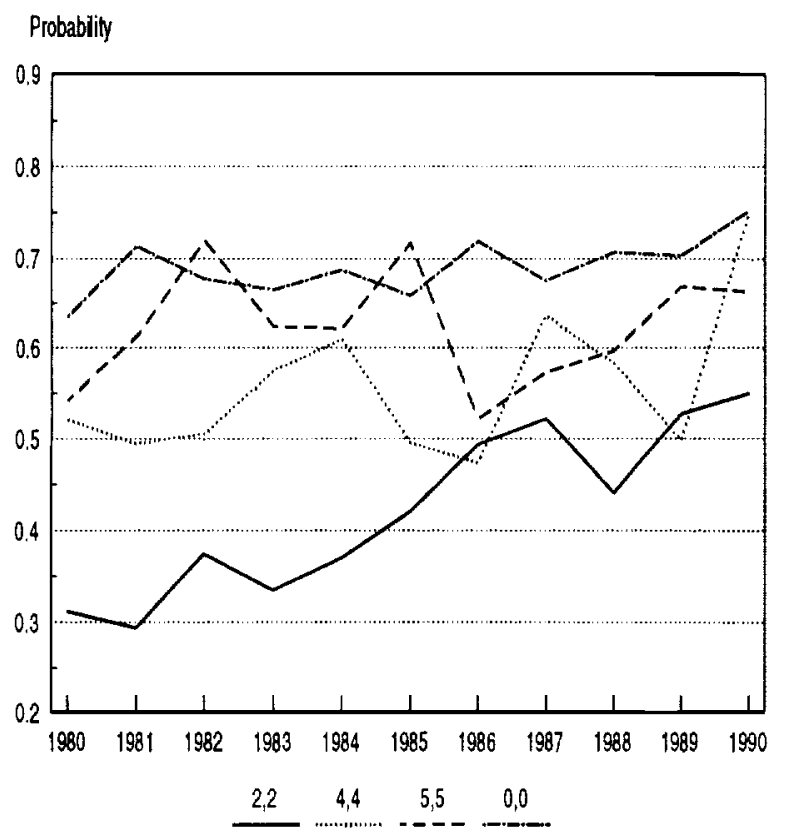

\section{c. 500 Weeks of Experience}

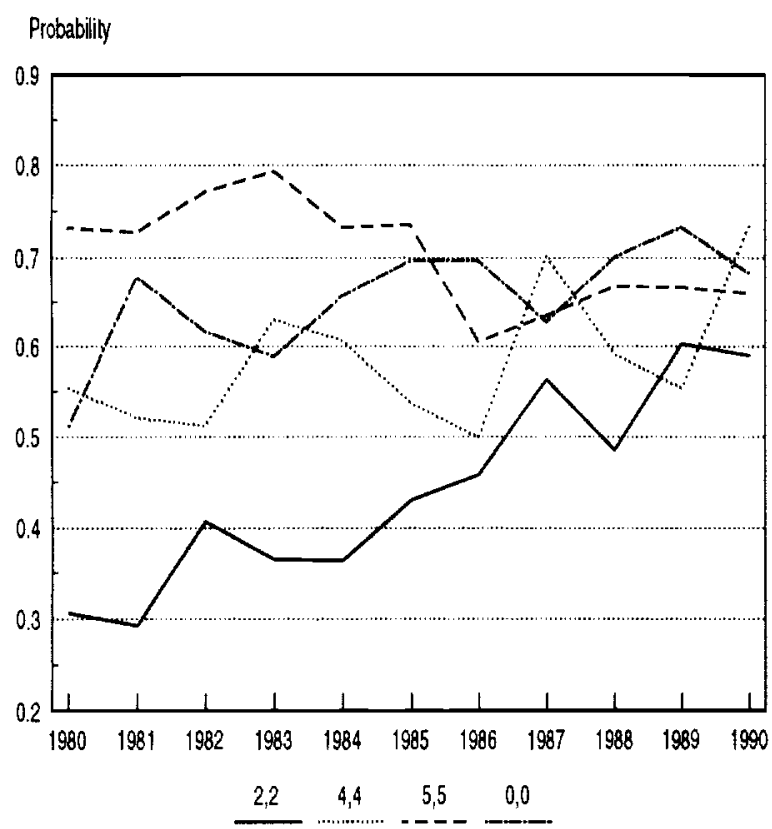

\section{b. 300 Weeks of Experience}

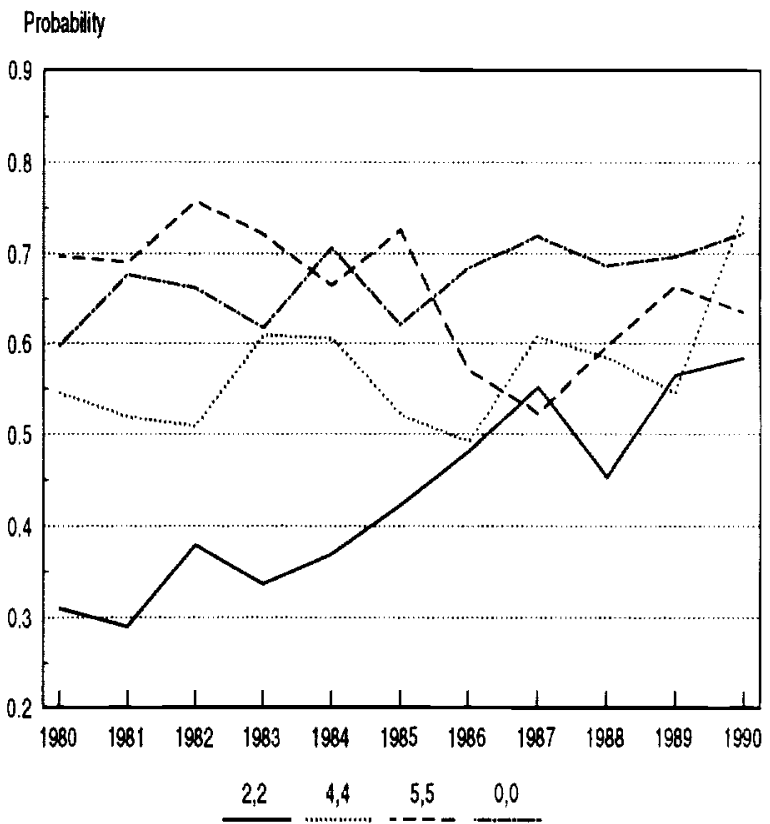

Note: The notation 2,2 denotes the probability of staying in the second quintile, and similarly for the other quintiles. The notation 0,0 denotes staying outside the distribution. 


\section{Figure 7: Conditional Staying Probabilities of Earnings, by Quintiles College Graduates}

\section{a. 100 Weeks of Experience}

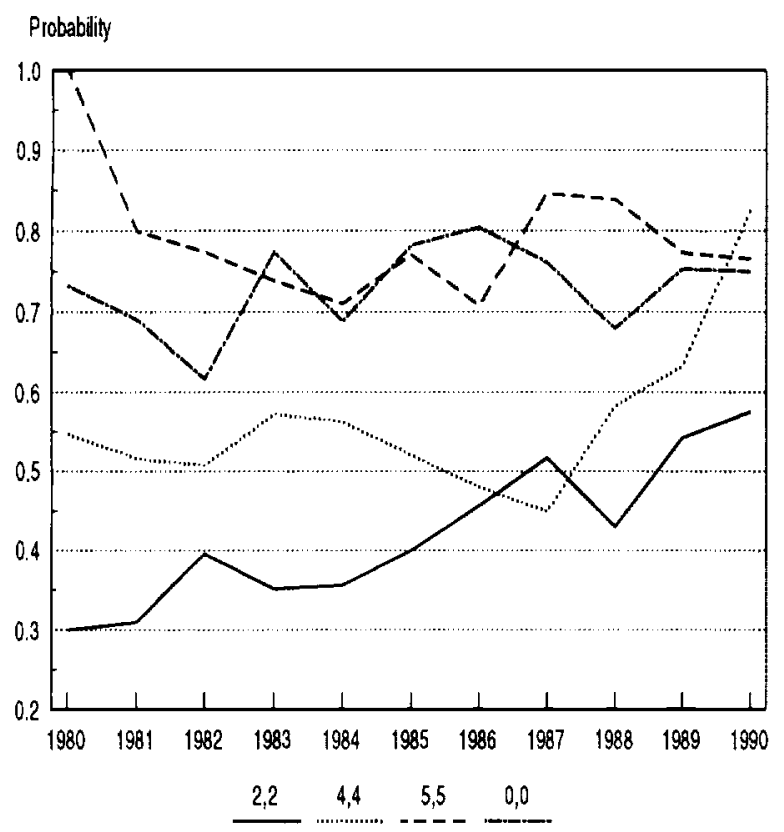

\section{c. 500 Weeks of Experience}

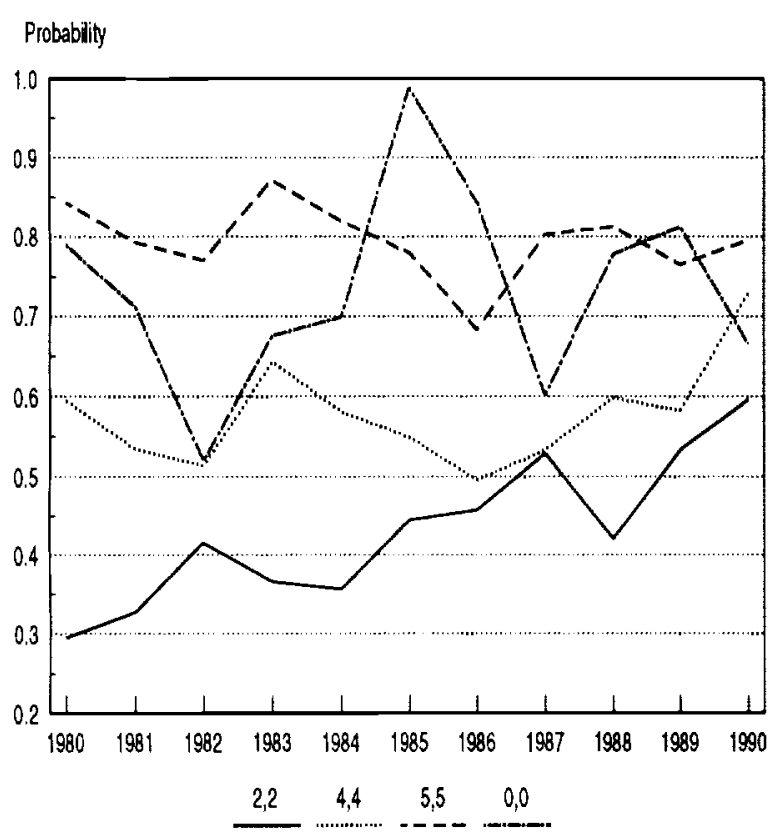

\section{b. 300 Weeks of Experience}

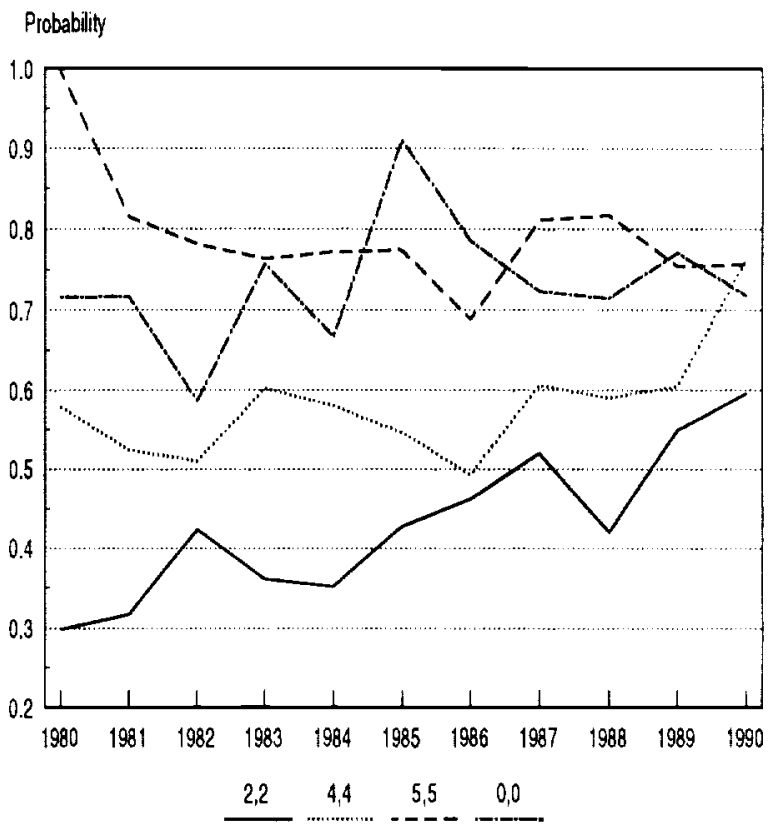

Note: The notation 2,2 denotes the probability of staying in the second quintile, and similarly for the other quintiles. The notation 0,0 denotes staying outside the distribution. 


\section{Figure 8: Average Quintile Jump of Earnings by Experience and Education}

\section{a. 100 Weeks of Expenence}

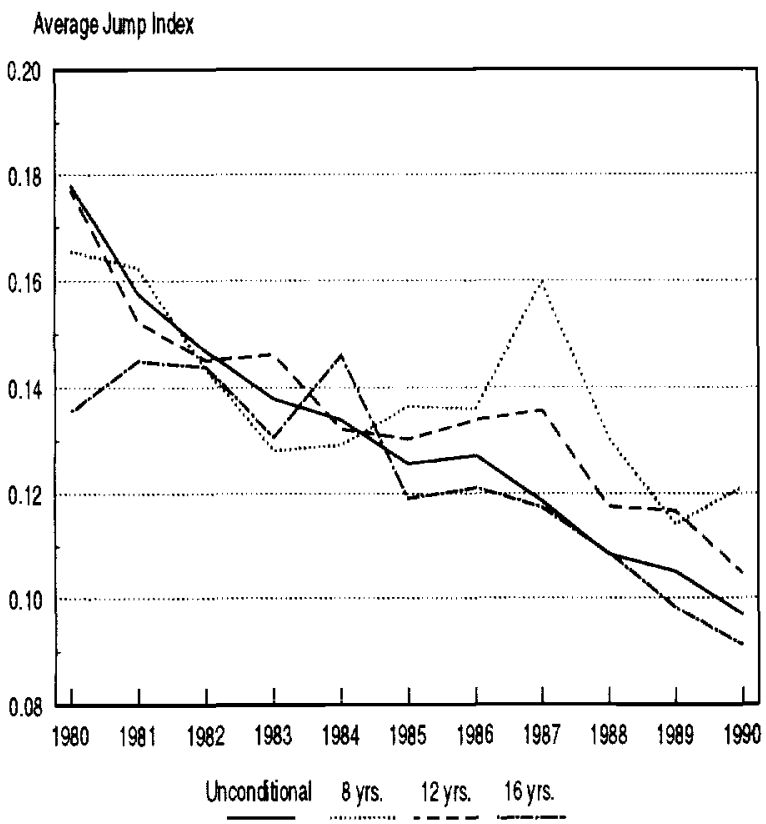

\section{c. 500 Weeks of Experience}

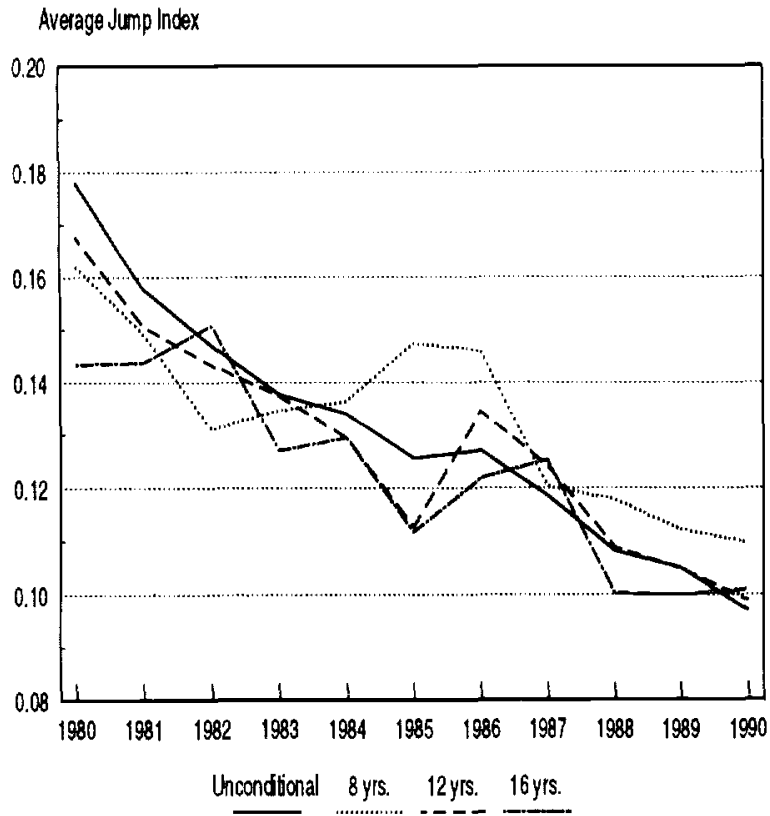

\section{b. 300 Weeks of Experience}

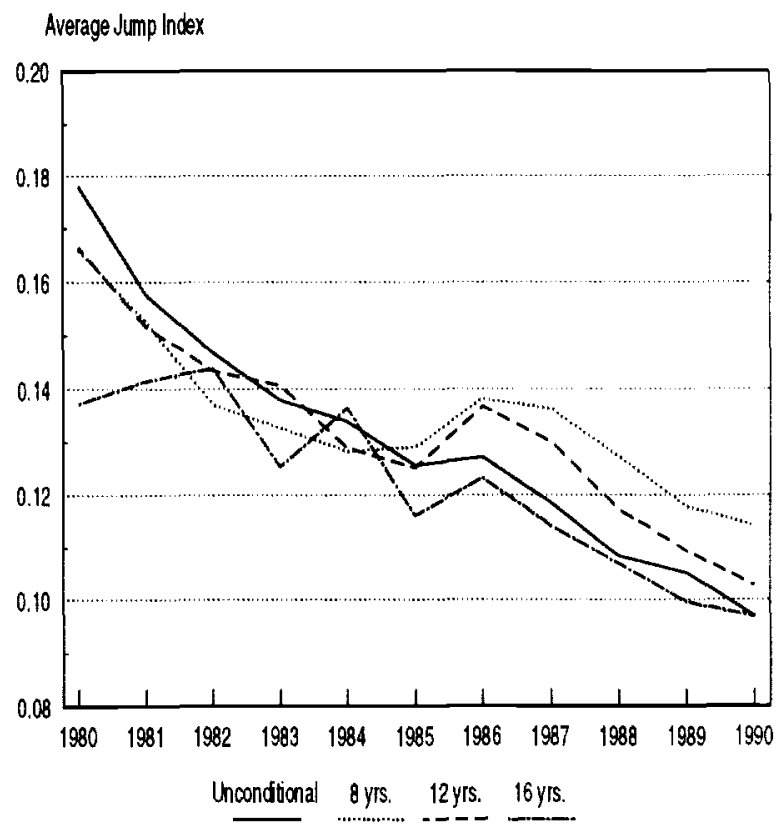

Note: See the text for the definition of the Average Jump index. 8 yrs. denotes elementary school graduates, and simlilarly for the other levels of education. Unconditional denotes the measure calculated for the entire sample. 
Figure 9: Mean of Reciprocal Exit Time of Earnings by Experience and Education

\section{a. 100 Weeks of Experience}

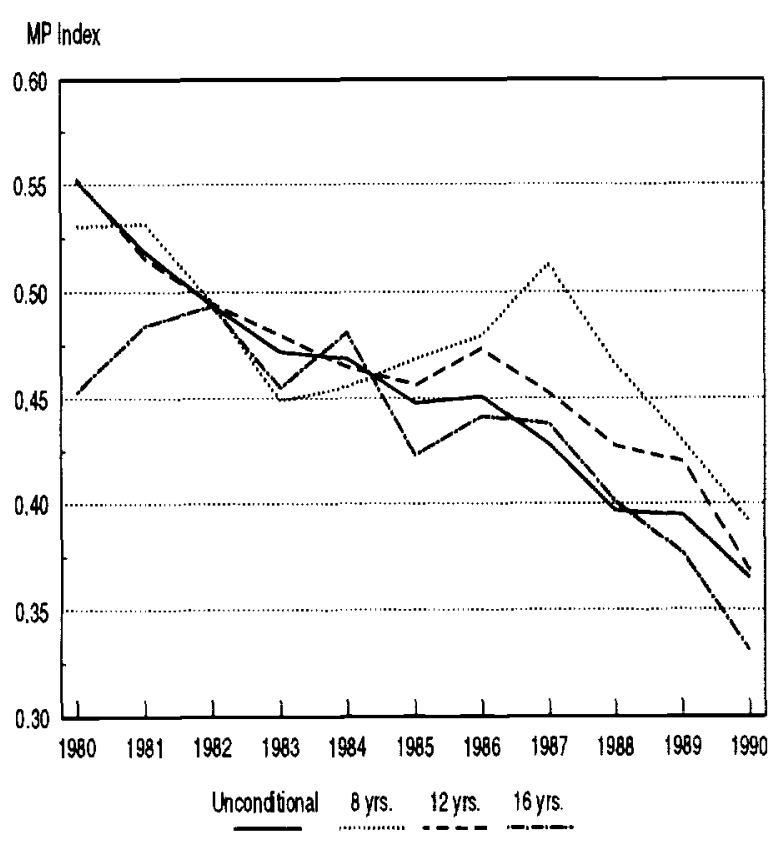

\section{c. 500 Weeks of Experience}

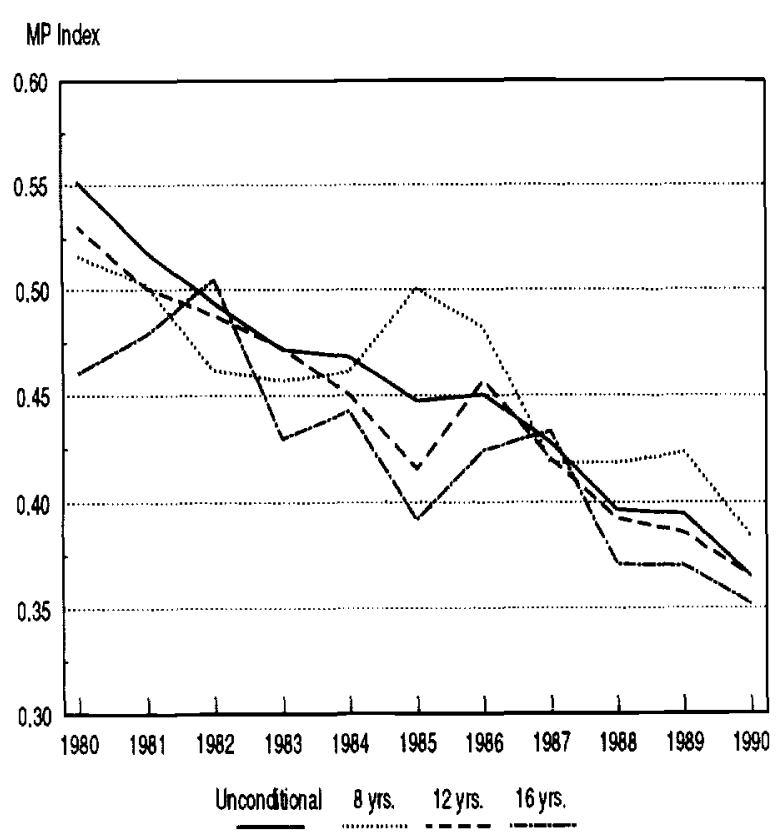

\section{b. 300 Weeks of Experience}

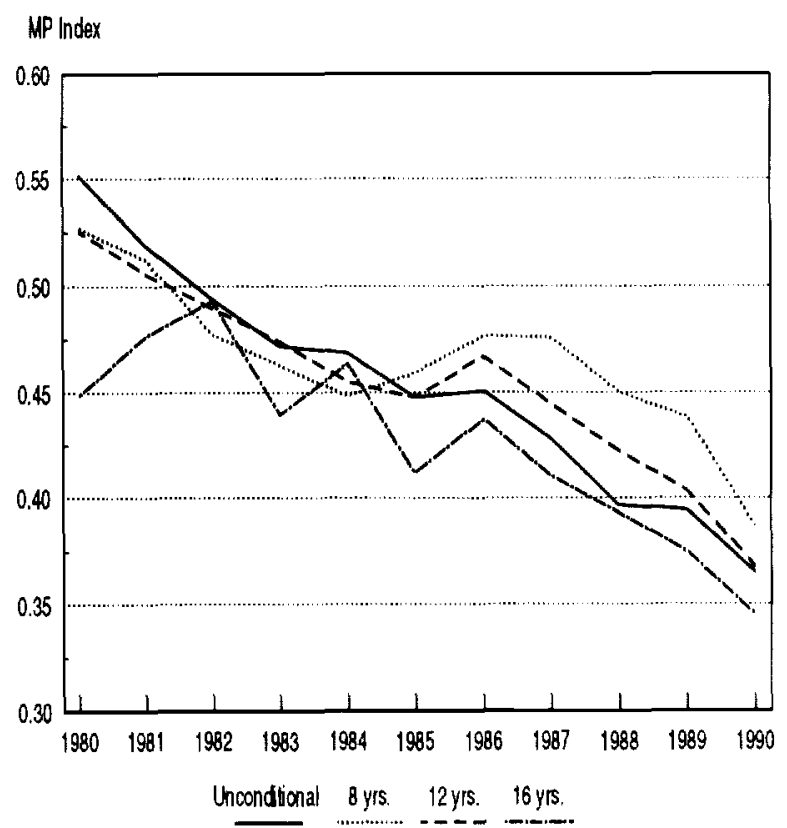

Note: See the text for the definition of the MP index. 8 yrs. denotes elementary school graduates, and simlilarly for the other levels of education. Unconditional denotes the measure calculated for the entire sample. 


\section{Figure 10: Average Quintile Jump of Wages by Experience and Education}

\section{a. 100 Weeks of Experience}

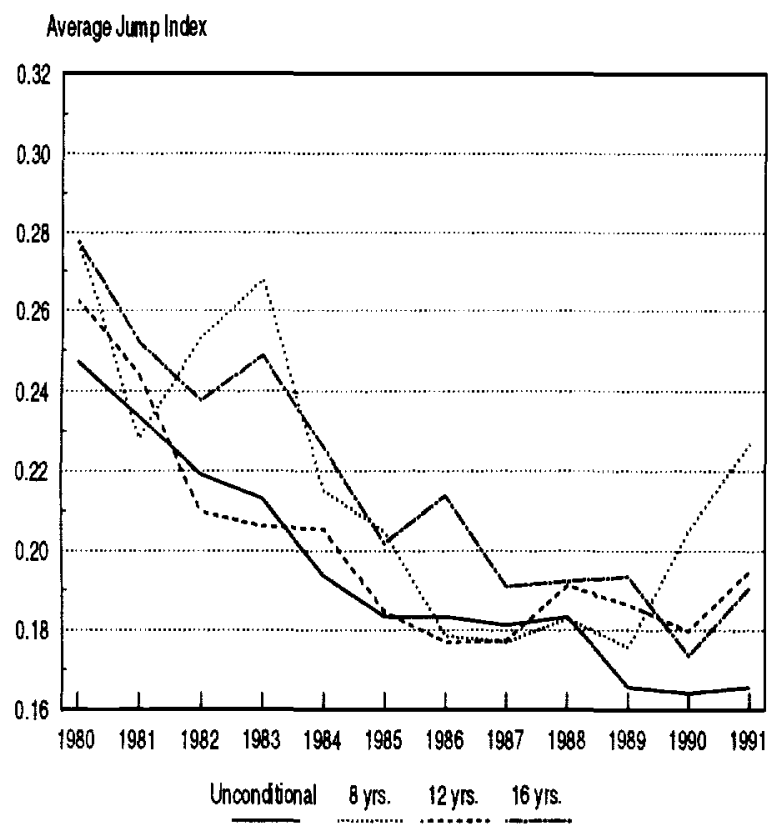

\section{c. 500 Weeks of Experience}

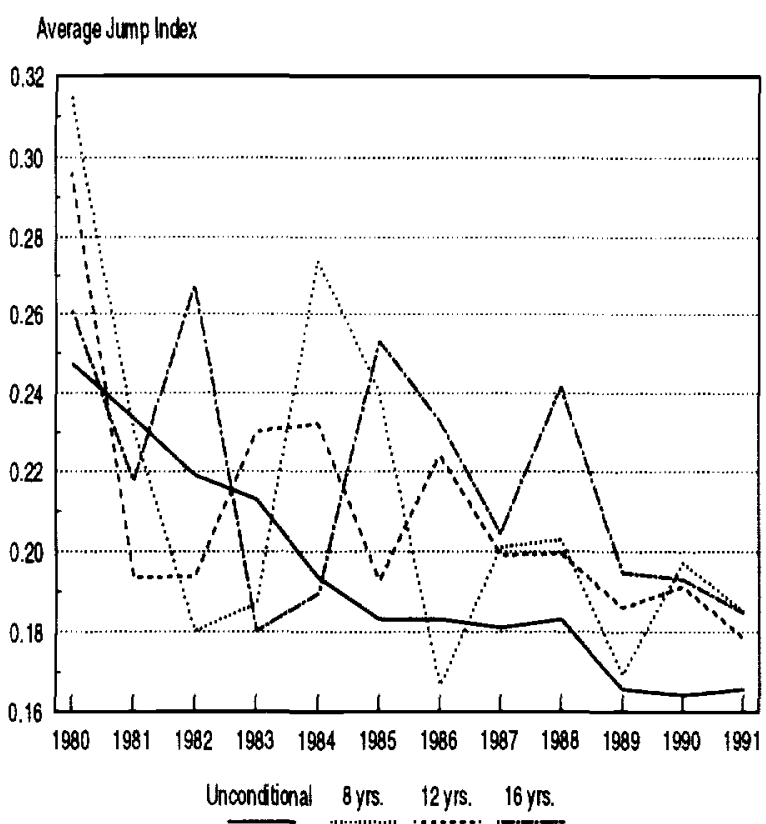

\section{b. 300 Weeks of Experience}

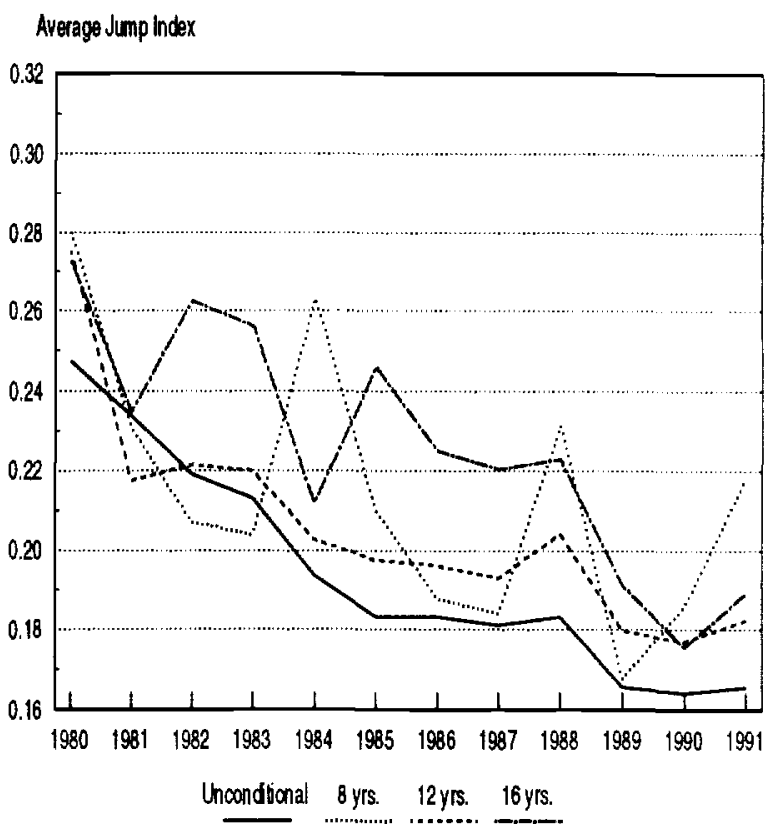

Note: See the text for the definition of the Average Jump index. 8 yrs. denotes elementary school graduates, and simlilarly for the other levels of education. Unconditional denotes the measure calculated for the entire sample. 
Figure 11: Mean of Reciprocal Exit Time of Wages by Experience and Education

\section{a. 100 Weeks of Experience}

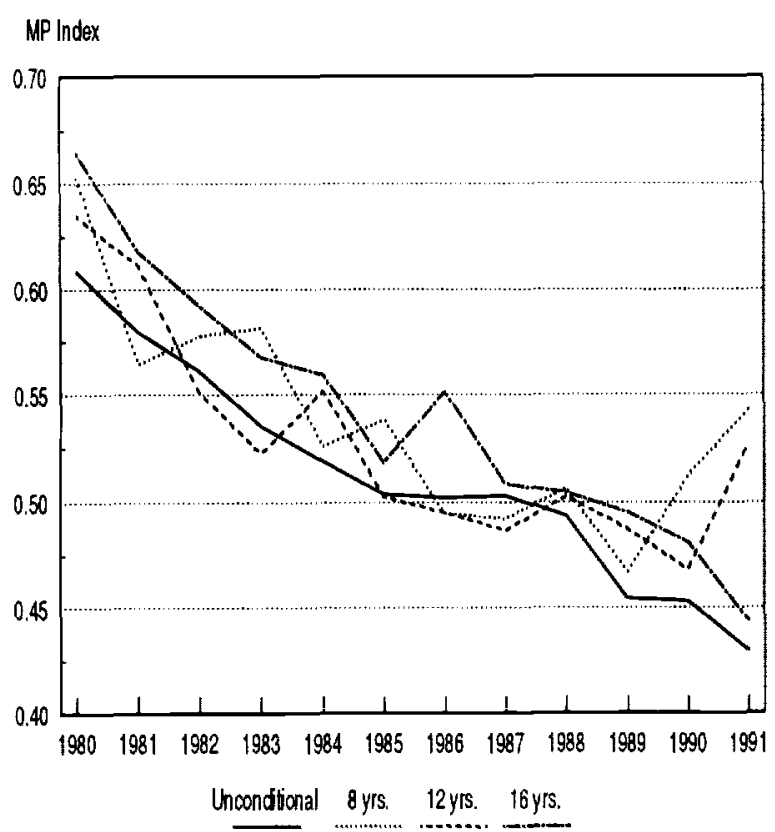

\section{c. 500 Weeks of Experience}

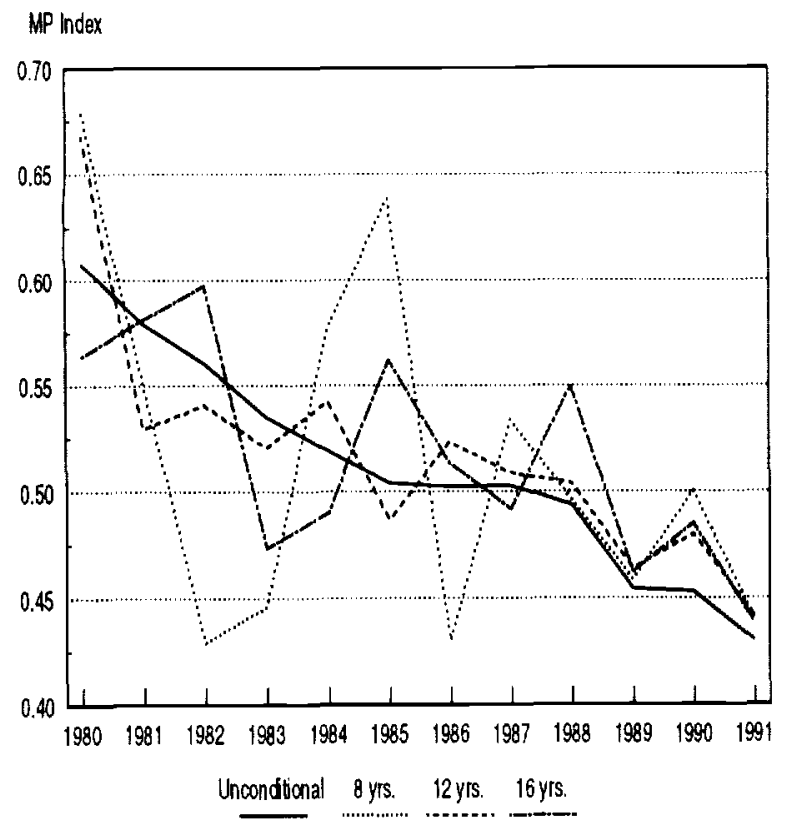

b. 300 Weeks of Experience

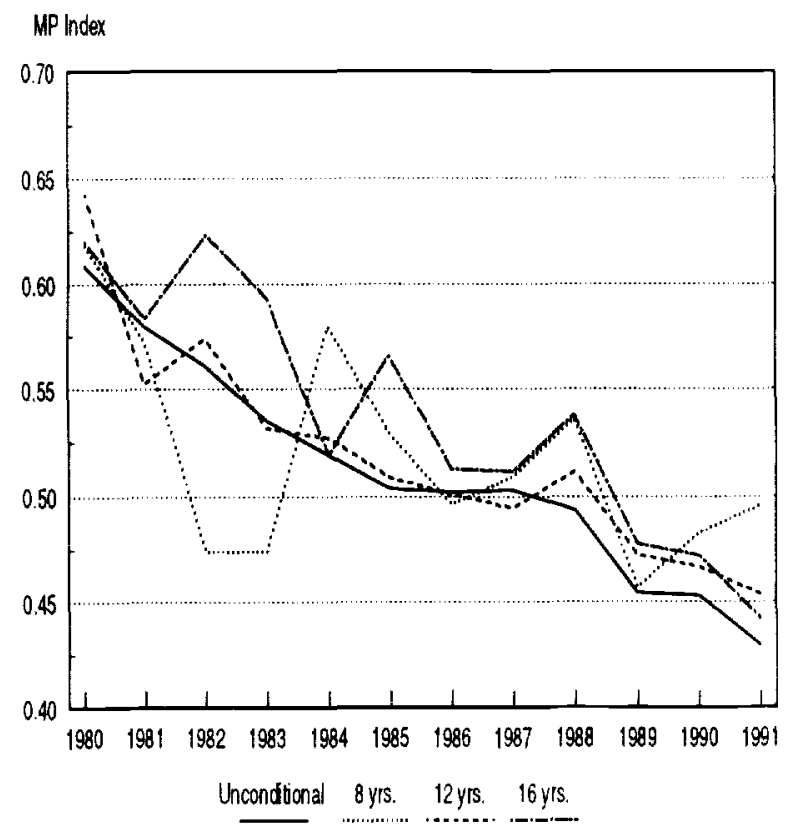

Note: See the text for the definition of the MP index. 8 yrs. denotes elementary school graduates, and simlilarly for the other levels of education. Unconditional denotes the measure calculated for the entire sample. 